
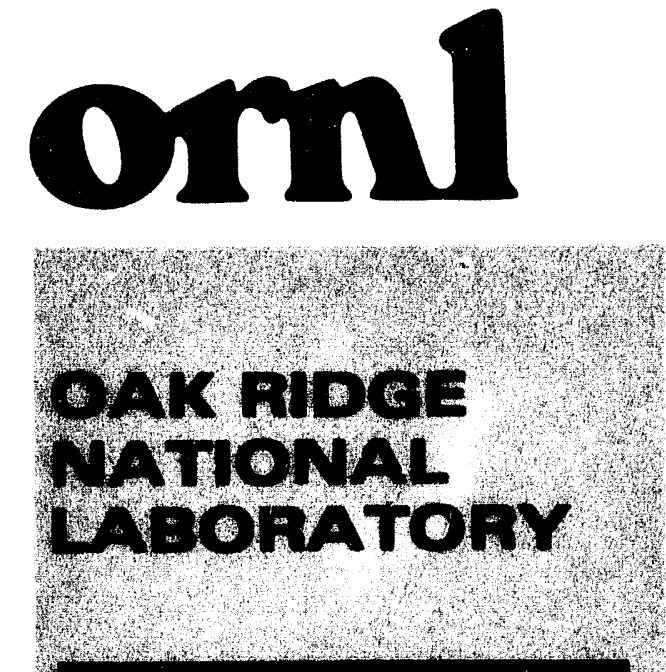

MARTIN MARUETTA

\title{
RECEIVED
}
JAN 31 1994
OSTI

\section{WEATHERIZATION WORKS: An Interim Report of the National Weatherization Evaluation}

\author{
Marilyn A. Brown \\ Linda G. Berry \\ Laurence F. Kinney
}

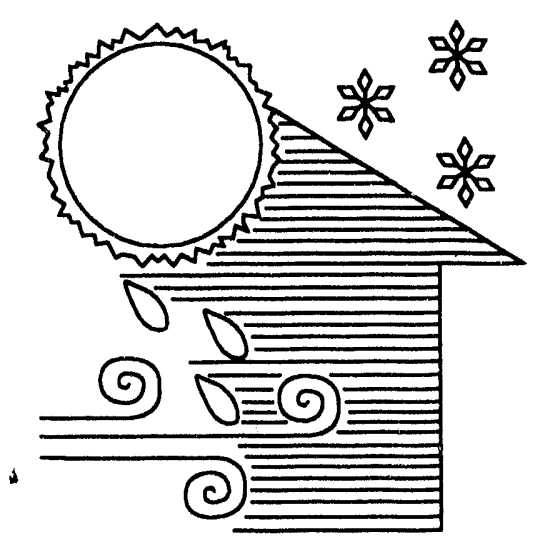


This report has been reproduced directly from the best available copy.

Available to DOE and DOE contractors from the Office of Scientific and Technical Information, P.O. Box 62, Oak Ridge, TN 37831; prices available from (615) 576-8401, FTS 626-8401.

Available to the public from the National Technical Information Service, U.S. Department of Commerce, 5285 Port Royal Rd., Springfield, VA 22161.

This report was prepared as an account of work sponsored by an agency of the United States Government. Neither the United States Government nor any agency thereof, nor any of their employees, makes any warranty, express or implied, or assumes any legal liability or responsibility for the accuracy, completeness, or usefulness of any information, apparatus, product, or process disclosed, or represents that its use would not infringe privately owned rights. Reference herein to any specific commercial product, process, or service by trade name, trademark, manufacturer, or otherwise, does not necessarily constitute or imply its endorsement, recommendation, or favoring by the United States Government or any agency thereof. The views and opinions of authors expressed herein do not necessarily state or reflect those of the United States Government or any agency thereof. 


\title{
WEATHERIZATION WORKS: An Interim Report of the National Weatherization Evaluation
}

\author{
Marilyn A. Brown \\ Linda G. Berry \\ Laurence F. Kinney*
}

* Synertech Systems Corporation

November 1993

\section{Prepared for the \\ Weatherization Assistance Programs Division \\ U.S. Department of Energy}

Prepared by the

Oak Ridge National Laboratory

Oak Ridge, Tennessee 37831

Managed by

Martin Marietta Energy Systems, Inc.

for the

U. S. Department of Energy

under Contract DE-AC05-84OR21400 


\section{Weatherization Works: \\ An Interim Report of the National Weatherization Evaluation At a Glance}

\section{NATIONAL SAMPLE OF SINGLE-FAMILY AND SMALL MULTIFAMULY HOMES}

Number of Local Weatherization Agencies

Number of Weatherized Dwellings with Agency Data ${ }^{a}$

Number of Utilities Providing Data

Number of Weatherized Dwellings with Utility Data
368 (of 400 in original sample)

14,971 (of 18,748 in original sample)

543 (of 926 contacted)

4,796 (of 13,162 gas or electrically heated dwellings)

\section{NORTHEAST SAMPLE OF FUEL-OIL HEATED HOMES}

Number of Local Weatherization Agencies

Number of Weatherized Dwellings with Agency and Fuel-Use Data

42 (from 9 Northeastern States where $70 \%$ of fuel-oil heated homes are located)

222 (sampled from population of about 23,000 homes)

\section{ENERGY SAVINGS}

Eirst-year Savings

Gas $(50.6 \%$ of weatherized homes)

Electricity ( $9.5 \%$ of weatherized homes)

Fuel oil ( $16.0 \%$ of weatherized homes)

All fuels (100\% of weatherized homes)

\section{High Gas Savings}

Cold climate region

Single - family detached dwellings

10 exemplary agencies $^{b}$

\section{Low Gas Savings}

Hot climate region

Mobile homes

20-year Savings

All fuels

VALUE OF BENEEITS

Gas Savings

Electricity Savings

Fuel-Oil Savings

Savings of All Fuels

Nonenergy Benefits

COST-EFEECTIVENESS

Program B/C Ratio

Societal B/C Ratio

\section{Savings Per Dwelling}

17.3 MBtu

6.2 MBtu (site)

18.9 MBtu (source)

$22.4 \mathrm{MBtu}$

17.6 MBtu (source)

23.5 MBtu

18.4 MBtu

34.7 MBtu

9.1 MBtu

12.0 MBtu

69.7 trillion Btu's or the equivalent of 12 million barrels of oil

$\begin{array}{ll}13.0 \% & 18.3 \% \\ 12.2 \% & 35.9 \% \\ & \\ 17.7 \% & 17.7 \% \\ 13.5 \% & 18.2 \%\end{array}$

$17.7 \%$

$14.1 \%$

$23.7 \%$

$24.9 \%$

$19.9 \%$

$33.4 \%$

$10.9 \%$

$12.0 \%$

$15.4 \%$

$16.9 \%$

\begin{abstract}
First year
$\$ 101 /$ dwelling

$\$ 128 /$ dwelling

$\$ 162 /$ dwelling

$\$ 116 /$ dwelling

$\$ 816 /$ dwelling
\end{abstract}

Gas-Heated

1.06

1.61
Electrically Heated

1.13
2.33
Euel-Oil Heated

1.48

2.01
20 years

$\$ 1,605 /$ dwelling $\$ 1,728 /$ dwelling $\$ 2,694 /$ dwelling $\$ 1,690 /$ dwelling \$976/dwelling

All Fuels

1.09

1.72

a Agency data included information on household demographics, weatherization procedures, measures installed, and costs. These data wer' collected for dwellings heated with all fuel types and for all dwelling types except large multifamily buildings (which were 9\% of the total dwellings weatherized in PY 1989).

b A geographically dispersed set of 10 exemplary agencies was sampled for analysis in the second phase of the Single-Family Study.

c The program benefit/cost ratio compares the discounted value of energy savings to total program costs with an assumed lifetime of 20 years and a discount rate of $4.7 \%$.

d The program benefit/cust ratio compares the discounted value of energy savings to tot?l nrogram costs with an assumed lifetime of 20 years and a discount rate of $4.7 \%$. 


\section{CONTENTS}

The National Weatherization Evaluation is described in two ways in this summary document. The text on the right-hand (odd) pages summarizes the results of the evaluation conducted by the Oak Ridge National Laboratory. The photographs and explanations on the left-hand (even) pages illustrate weatherization operation and tactics.

\section{Even pages}

Remarks by President Clinton

Housing Stock

Single-Family Detached Homes.

Row Homes

Mobile Homes

Doors and Windows

Air Infiltration/Exfiltration

Basements

Blower Doors

Dense Pack Cellulose

Advanced Air Sealing.

Heating Systems

Distribution Systems

Domestic Hot Water

Attics

Mobile Homes Measures

National Energy Audit

Targeting Savings Potential

Putting It All Together

Acknowledgments

\section{Odd pages}

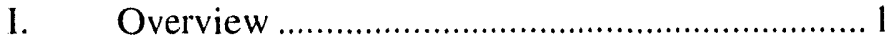

II. Program History ............................................ 3

III. The Scope of Weatherization .............................. 5

A. Types of Measures Used ............................. 5

B. Sources of Funds ......................................... 7

C. Uses of Funds: DOE Sets the Pace ........... 9

D. DOE Outperforms Utilities .......................

IV. The Evaluation Process ................................. 11

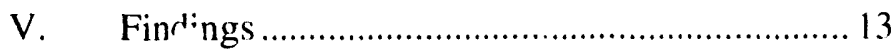

A. Diversity of Dwellings and Agencies ....... 13

The Typical Dwellings ............................. 15

The Typical Agency ................................ 15

B. Program Benefits ................................... 17

National Energy Savings ........................... 17

Health, Safety, Jobs, and Environment ..... 19

C. Cost-Effectiveness ................................... 21

Program Costs ...................................... 21

National Cost-Effectiveness..................... 23

E. Performance by Climate Region .......................25

Cold Climate Region............................... 25

Moderate Climate Region ....................... 27

Hot Climate Region ................................. 29

VI. Foundations for Change …................................. 31

A. Savings Associated With Specilic

Program Practices ........................................ 31

B. Promising Management Practices ............... 33

VII. The Future of Weatherization: Next Steps ........ 35

A. Service Delivery Procedures ......................... 35

B. Weatherization Measures ............................ 37

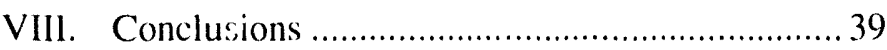

References and Notes ................................... 41

Appendix A ............................................... 43-44 
"I have seen first hand how many jobs weatherization programs create and also how much good they can do ... A lot of this weatherization work for poor people, especially for a lot of elderly people who are stuck in these old houses that have holes in the walls ... or in the floor, not only makes them warmer in the winter and cooler in the summer, they also save money on their utility bills. [Weatherization] conserves energy and puts more money in the pockets of people who have just barely enough to get by. So I strongly support [weatherization programs] ... It's a kind of hard sell in the Congress now becausc the price of oil is so low and energy is so cheap-it's much cheaper in America than it is in any other major country. But if you just have enough to get by on, [if] you're living on a Social Security check or you're living on a minimum wage, [utility bills] are still very, very expensive and a big part of your budget."

President Clinton's remark: concerning the Department of Energy's Weatherization Assistance Program at the Summer of Service Forum held at the University of Maryland, August 31, 1993. 


\section{An Interim Report of the National Weatherization Evaluation}

\section{OVERVIEW}

In 1990, the U.S. Department of Energy (DOE) sponsored a comprehensive evaluation of its Weatherization Assistance Program, the nation's largest residential energy conservation program. Oak Ridge National Laboratory (ORNL) managed the five-part study. This document summarizes the interim findings of the evaluation. Its conclusions are based mainly on data from the 1989 program year (supplemented by data from 1991-92).

The evaluation concludes that the Program meets the objectives of its enabling legislation and fulfills its mission statement. Specifically, it

- saves energy,

- lowers fuel bills, and

- improves the health and safety of dwellings occupied by low-income people.

In addition, the Program achieves its mission in a cost-effective manner based on each of three perspectives employed by the evaluators. Finally, the evaluation estimates that the investments made in 1989 will, over a 20-year lifetime, save the equivalent of 12 million barrels of oil, roughly the amount of oil added to the Strategic Petroleum Reserve in each of the past several years.

The Program's mission is to reduce the heating and cooling costs for lowincome families-particularly the elderly, persons with disabilities, and children by improving the energy efficiency of their homes and ensuring their health and safety. Substantial progress has been made, but the job is far from over. The Department of Health and Human Services (HHS) reports that the average low-income family spends 12 percent of its income on residential energy, compared to only 3 percent for the average-income family. Homes where low-income families live also have a greater need for energy efficiency improvements, but less money to pay for them.

In combination with closely related programs sponsored by the HHS and supplemental funding from some states and electric and gas utility companies, DOE's weatherization network of 1,100 local agencies has retrofitted more than four million dwellings since the inception of the program. According to the Energy Information Administration, 27.9 million dwellings are occupied by households with incomes below 150 percent of the poverty level. This does not mean that 14 percent of currently eligible households ( 4 million of 27.9 million) have received weatherization services. The percentage is lower because households pass in and out of poverty and roughly one-quarter of them move each year. Nevertheless, weatherization programs have improved a significant proportion of the housing that is likely to be occupied by low-and moderate-income households.

\section{Notes and references are at the end of the text on page 41.}




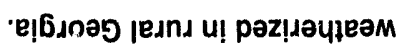

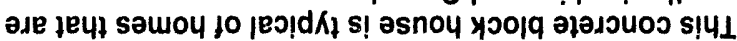

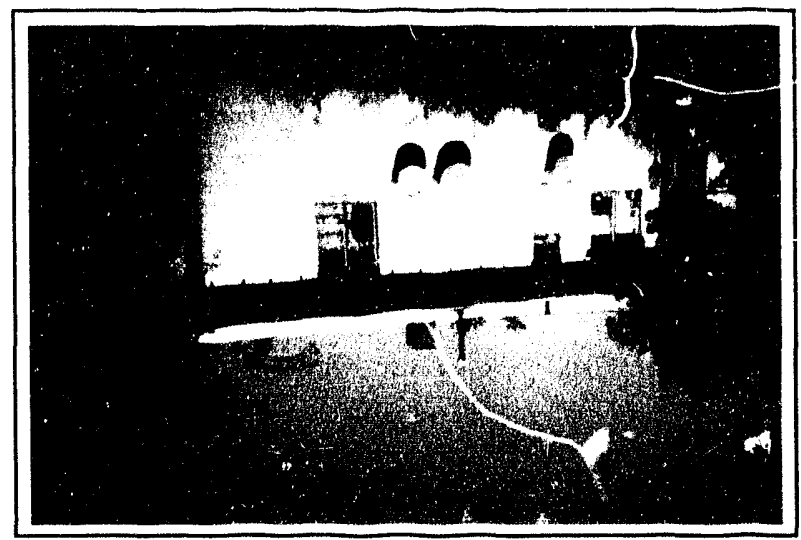

-गฺน 'uo!̣e|nsu! ॥eм 101 әцер!̣pues poo6 $\forall$

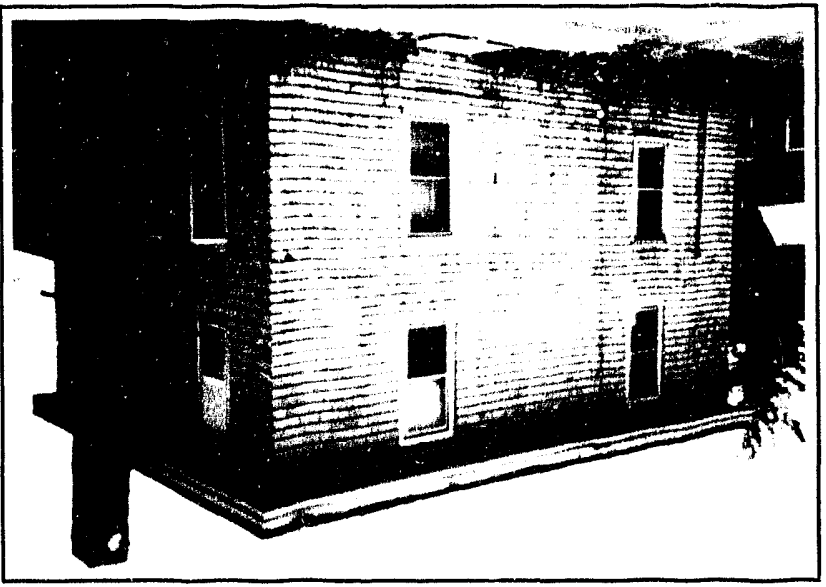

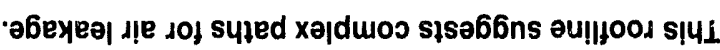

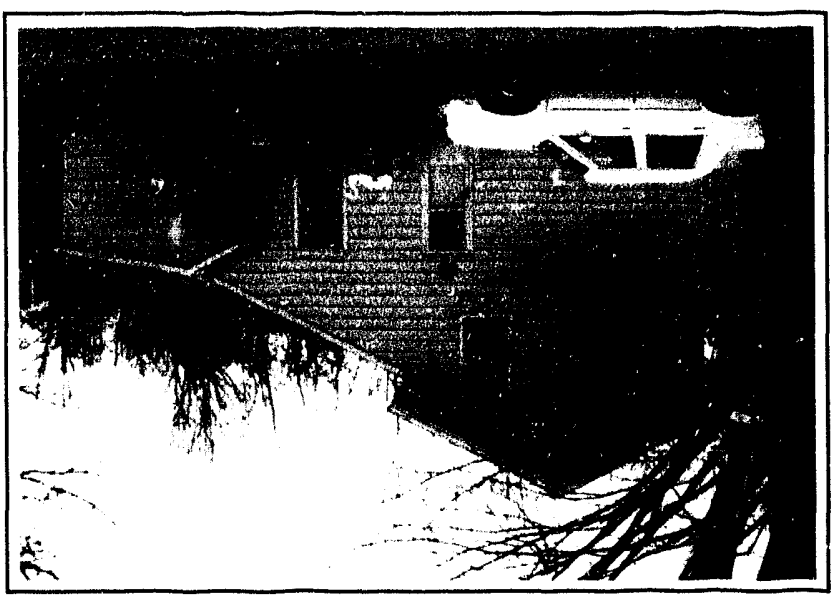

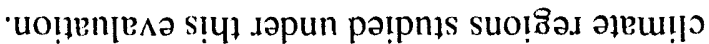

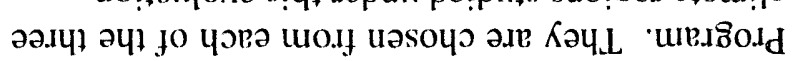

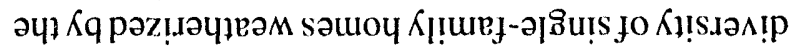

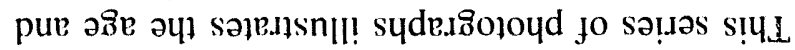

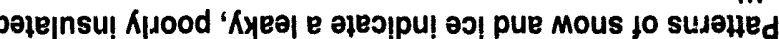

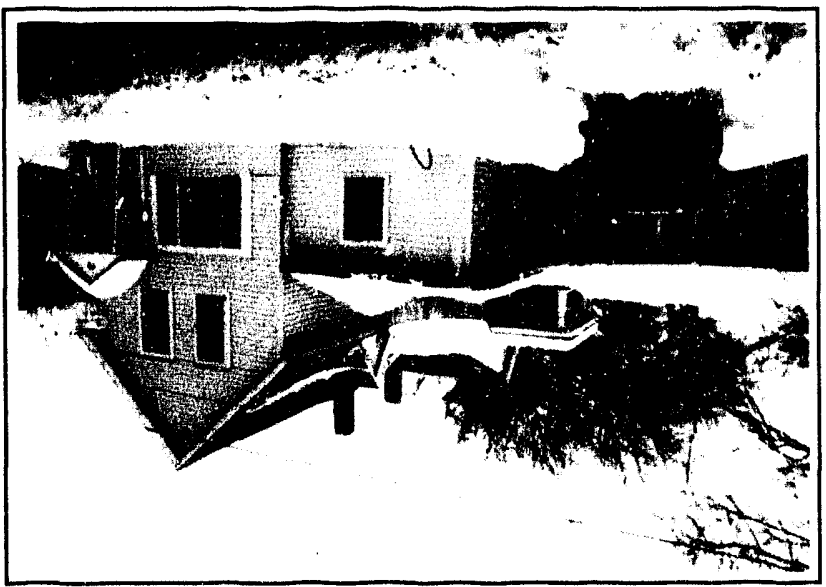

'd!edәd ॥ем uo!!

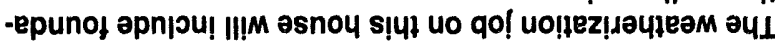

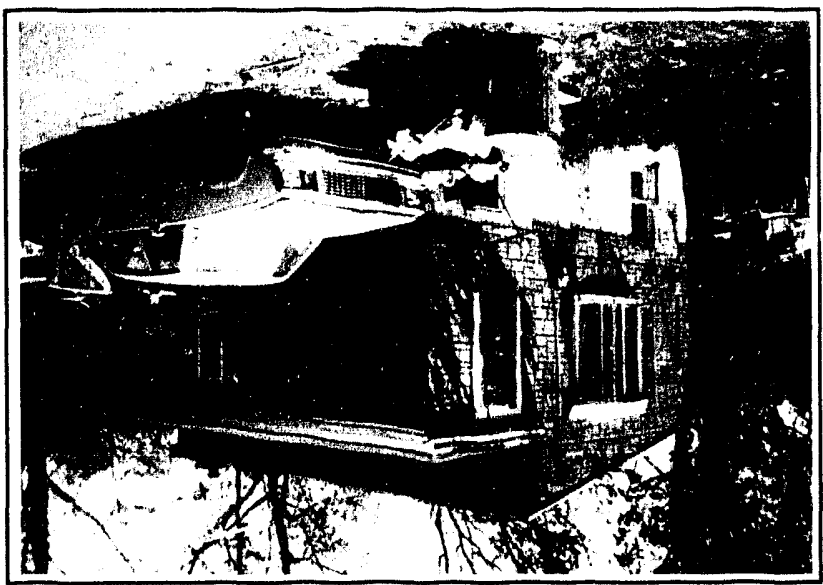

SHWOH QHHDVIGA XTIWVH-'GTDNIS 


\section{PROGRAM HISTORY}

The 1973 oil crisis hit Americans hard. Huge home heating bills hurt family budgets, sinking many into debt. The high heating bills hurt low-income families in colder states the most. In Maine, where nine out of ten homes are heated with oil, state officials and community action agencies worked with home owners and renters to seal house leaks where costly heated air poured out and cold air entered. Retrofitting cut bills and saved oil. Out of this effort, the nation's first weatherization program was born. Congress created DOE's Weatherization Assistance Program in 1976 under Title IV of the Energy Conservation and Production Act.

In its early years, the Program emphasized emergency and temporary measures, including caulking and weatherstripping windows and doors, and low-cost measures such as covering windows with plastic sheets. By the

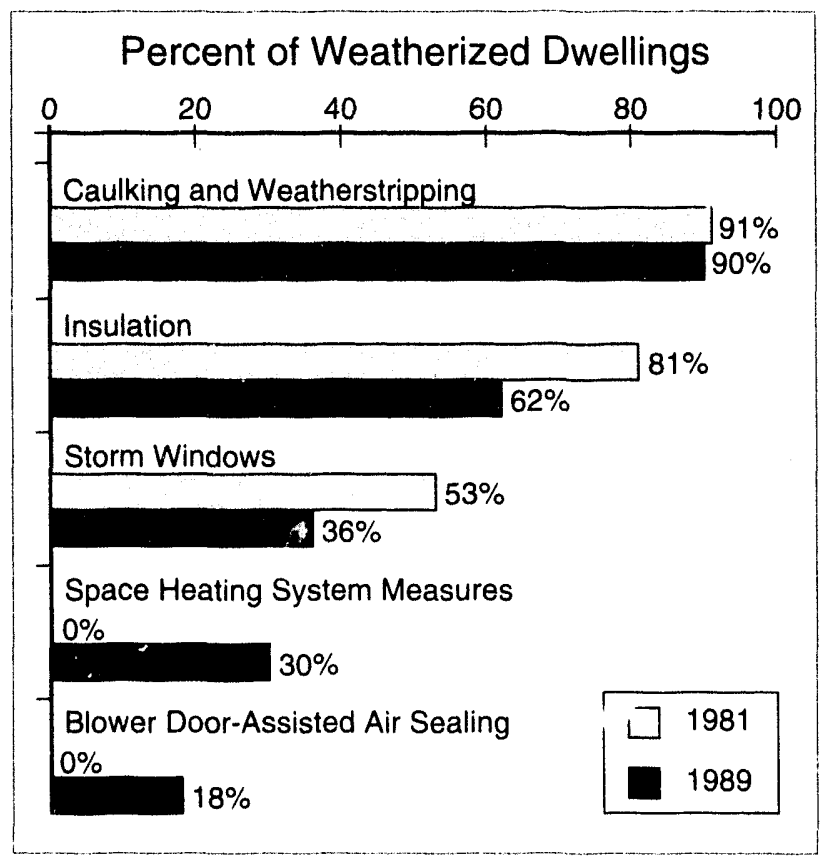

Installation Rates for Selected Weatherization Measures in Single-Family and Small Multifamily Homes, 1981 and $198 \%$. early 1980 s, the emphasis had turned to more permanent and more cost-effective measures such as installing storm windows and storm doors and attic insulation. In 1984, regulations were passed to allow weatherization assistance funds to be spent on space and water heating system efficiency changes. In 1985, replacement of furnaces and boilers was approved.

Recent years have seen the increasing use of space heating system measures (such as tune-ups and installation of furnace component retrofits) and sophisticated diagnostic tools (such as blower doors). The staff has become more professional, and quality control has gone beyond visual inspections during monitoring visits to include the use of sophisticated measurement procedures.

New regulations for 1993, which implement changes Congress authorized in 1990, encourage the use of health and safety enhancements and the most cost-effective techniques for saving energy. These new rules allow the use of cooling efficiency measures, including air conditioner replacement, ventilation equipment, and screening and shading devices. These measures will enable the Program to more effectively address the energy efficiency needs of hot climates. Barriers to performing work on heating systems and mechanical equipment also have been removed. The requirement that 40 percent of Progam funds be spent on materials is waived in states that adopt approved advanced audits, thus ensuring audit-driven cost-effective tests of investments. These and oth $\mathrm{r}$ changes allow the flex bility to select measures appropriate to particular regions and dwellings.

Funding for low-income weatherization has also changed. The most money was spent on weatherization in the 1980s. Funding levels have declined steadily since then. Despite funding changes, the Program has grown in scope and become more technically sophisticated. In 1989, 1,100 local agencies throughout the United States conducted weatherization operations using almost $\$ 500$ million from multiple funding sources to weatherize approximately 250,000 low-income homes. 


\section{SINGLE-FAMILY DETACHED HOMES}

\section{CONTINUED}

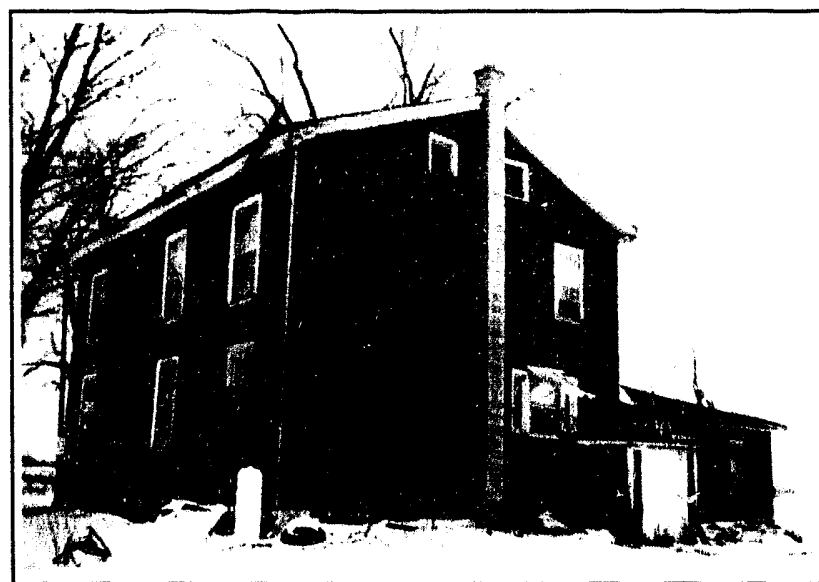

This farmhouse saved over 50 percent by air sealing, wall insulation, and furnace replacement.

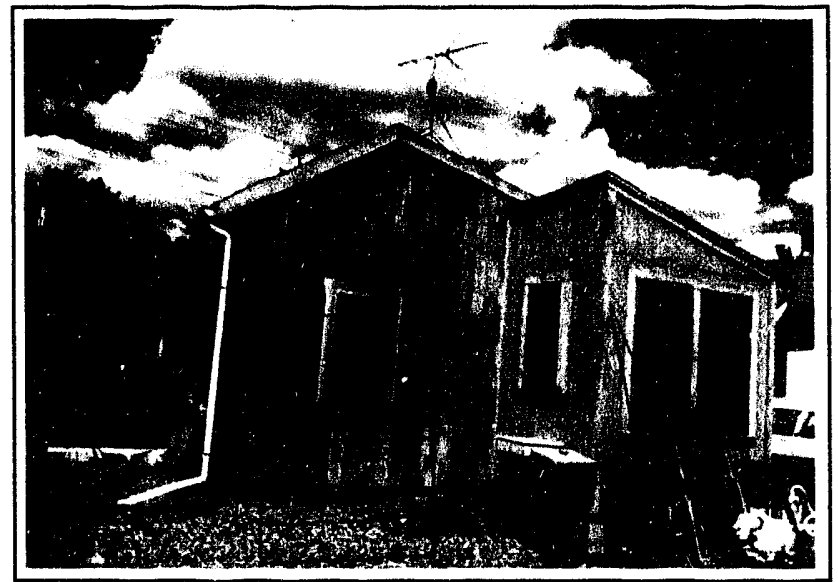

The interface between old and new is often a trouble spot.

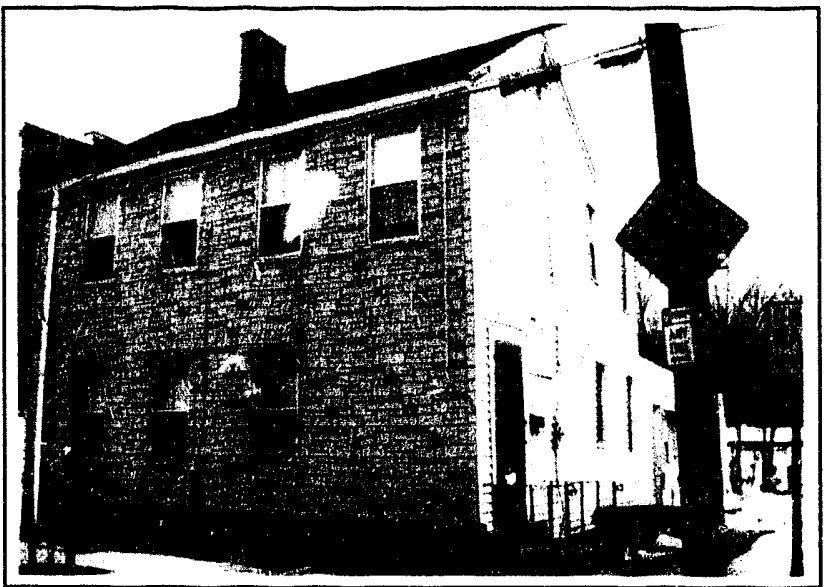

Retrofit siding hides major holes that cause air leakage.

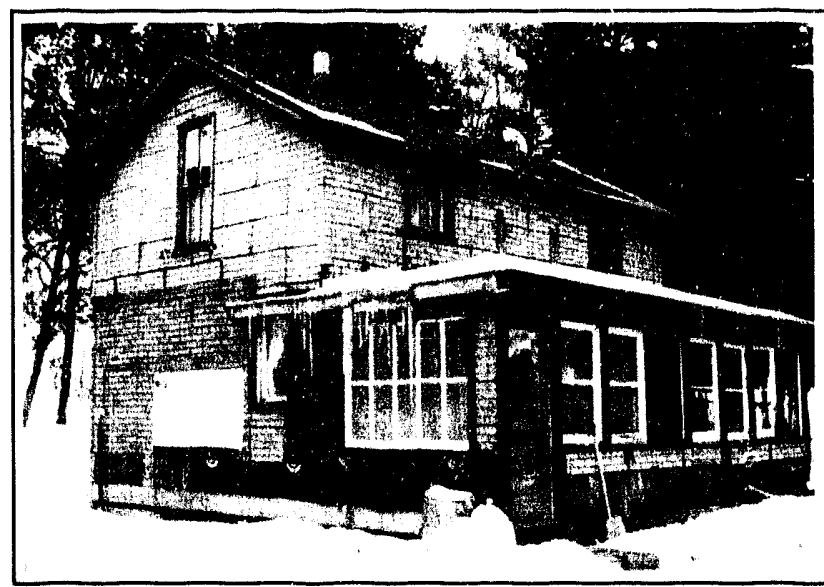

An uninsulated attic and air leakage between the porch and main structure are the main energy problems with this dwelling.

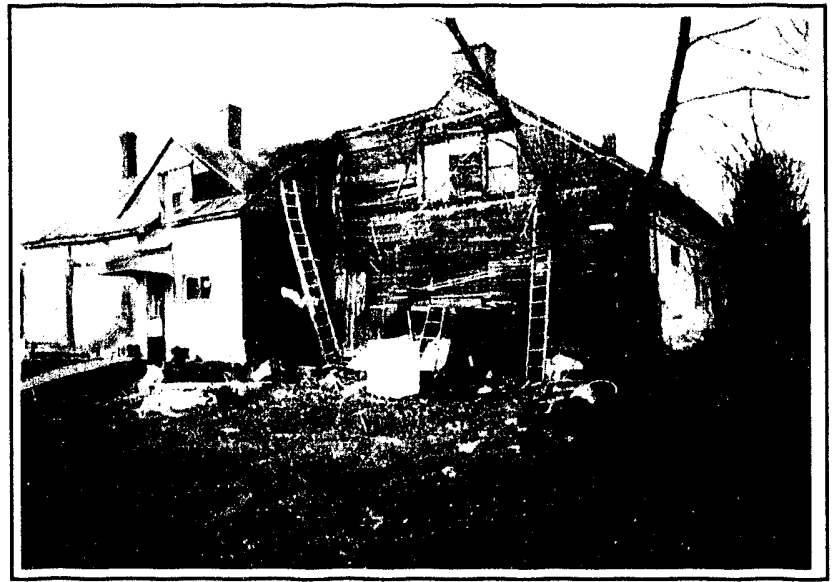

Movement of deteriorated foundation walls has opened large paths for air leakage.

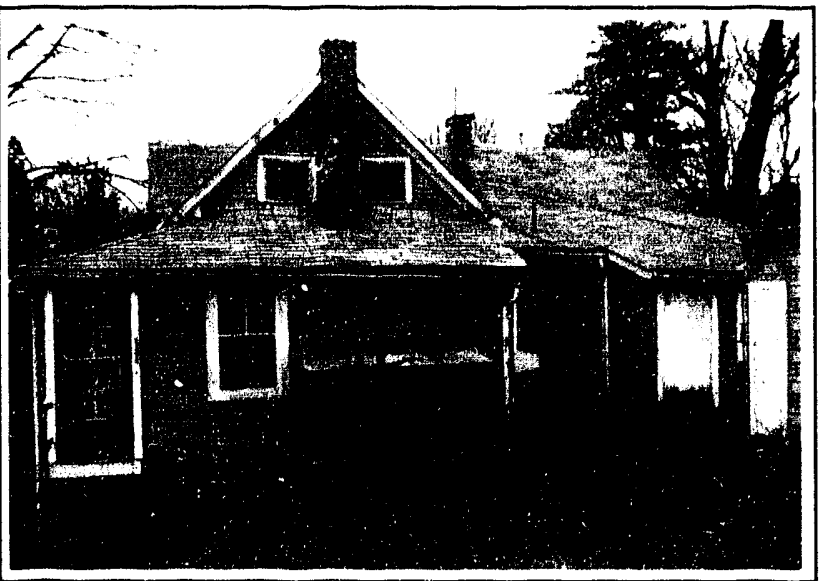

Built in sections over many years, this dwelling has major leaks between the main house and newer additions. 


\section{THE SCOPE OF WEATHERIZATION}

\section{A. Types of Measures Used}

A variety of weatherization measures are used by DOE's Weatherization Program to improve the energy efficiency of dwellings occupied by lowincome people.

Air leakage control was the most common type of weatherization measure installed in single-family and small multifamily dwellings in 1989. General caulking and weatherstripping around windows and doors was by far the most common of these measures. However, air sealing with blower doors ( 18 percent) and without blower doors ( 23 percent), and air leakage control measures for distribution systems ( 7 percent) were also common.

Insulation was the next most common type of energy conservation measure installed in 1989. Attic insulation was either installed for the first time or added to existing insulation in ine majority of homes that received insulation. The measures of conventional wall insulation, rim or band joist insulation, and floor insulation were each added to between 10 and 20 percent of all weatherized homes. High-density wall insulation, foundation or perimeter insulation, attic or hatch access door insulation, and duct and crawlspace insulation were added to between 1 and 2 percent of weatherized homes.

Energy-efficiency improvements to water heater systems were made in 56 percent of the weatherized homes. Most of these retrofits involved tank or pipe insulation. In addition, water temperatures were reduced and low-flow showerheads were added to approximately 10 percent of homes.

Energy-efficiency improvements to windows and doors occurred in 42 percent of homes weatherized in 1989. Additional window and door work was conducted primarily for repair purposes. By far, the majority of these improvements involved the addition of storm windows ( 36 percent) or the replacement of entire windows (37 percent). Altogether, storm windows were added or entire windows were replaced on 61 percent of the weatherized homes. Storm doors were added to 4 percent of the weatherized homes, and exterior doors were replaced on 38 percent of weatherized homes.

Nearly one-third ( 30 percent) of the homes weatherized in 1989 had energy-efficiency improvements made to their space heating systems. Most of these improvements involved tune-ups, during which the heating systems were cleaned, controls adjusted, and filters replaced. Heating system component retrofits were completed in 7 percent of the waatherized homes. Entire heating systems were replaced in approximately 4 percent of homes.

Different types of measures are considered when weatherizing large multifamily buildings. These include heating, ventilating, and air conditioning control systems ana various ventilation system modifications. 
Although almost two-thirds of the dwellings weatherized in the year of the study are singlefamily detached structures, otherdwelling types are also common.

\section{ROW HOMES (SINGLE-FAMILY ATTACHED DWELLINGS)}

Row homes, which predominate in many older American cities in the Northeast, can be extremely wasteful of energy. Leaky flat roofs cause falling ceilings and massive air leakage.

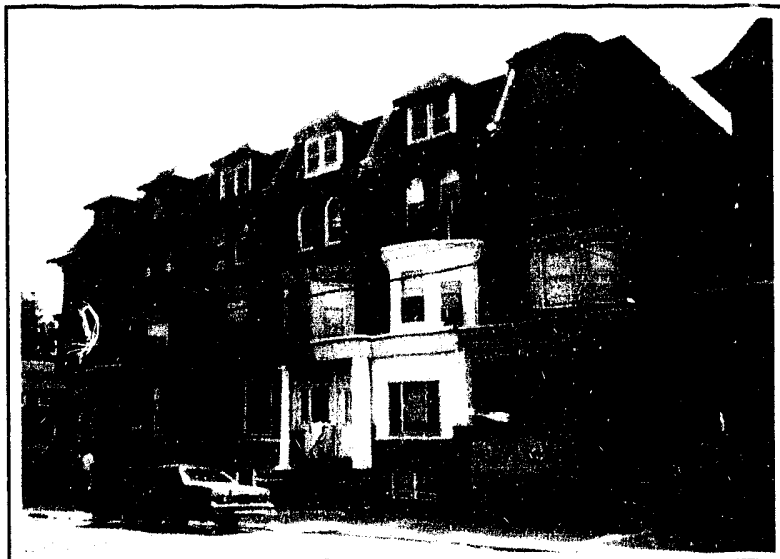

The space above porch ceilings is often connected to the inside of the front wall.

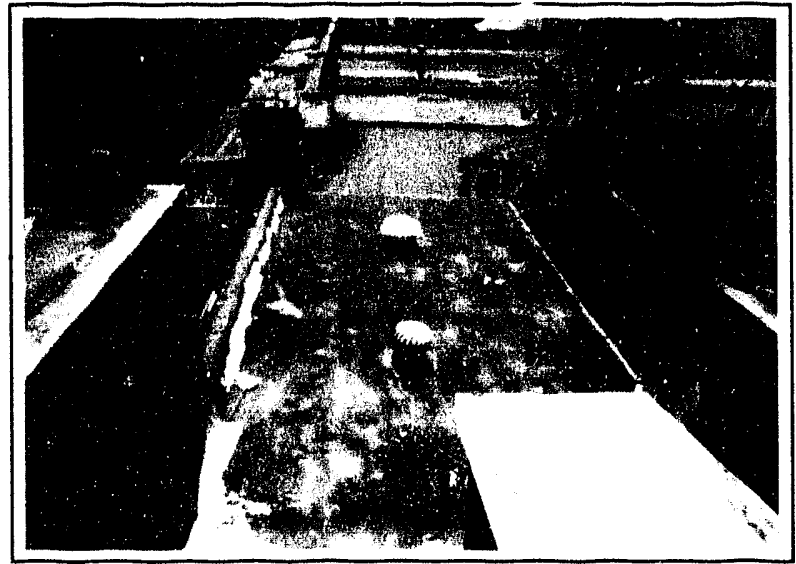

Leaky roofs pose big problems.

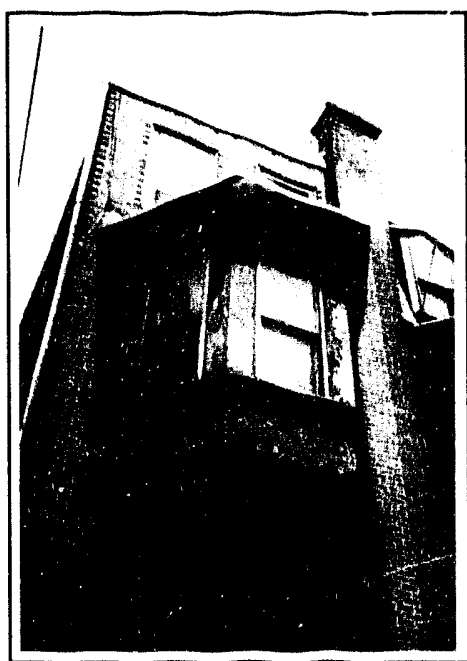

The space under these bay windows may cause more energy waste than the windows themselves.

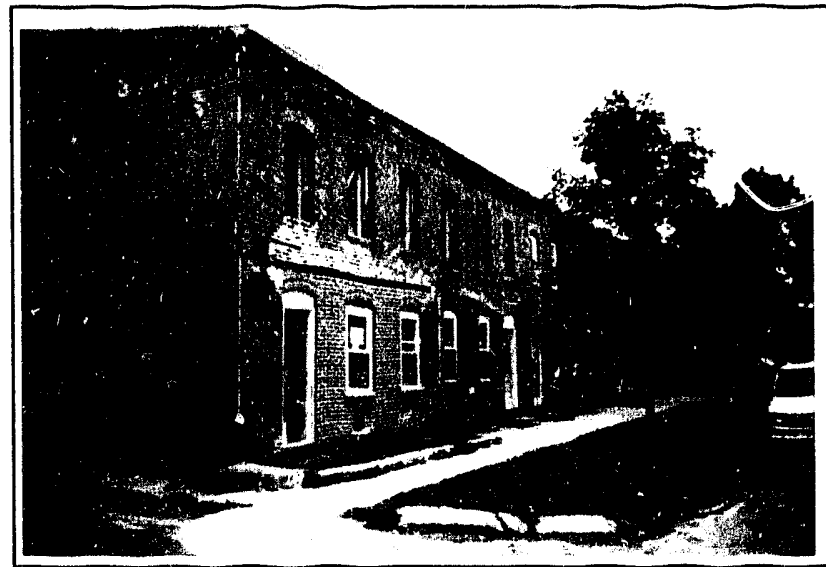

A solid exterior may conceal inner decay.

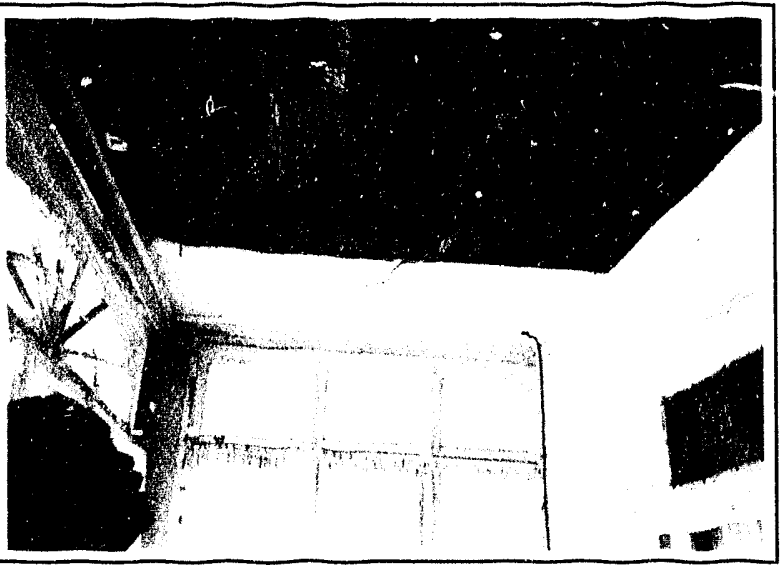

The consequences of unrepaired roof leaks.

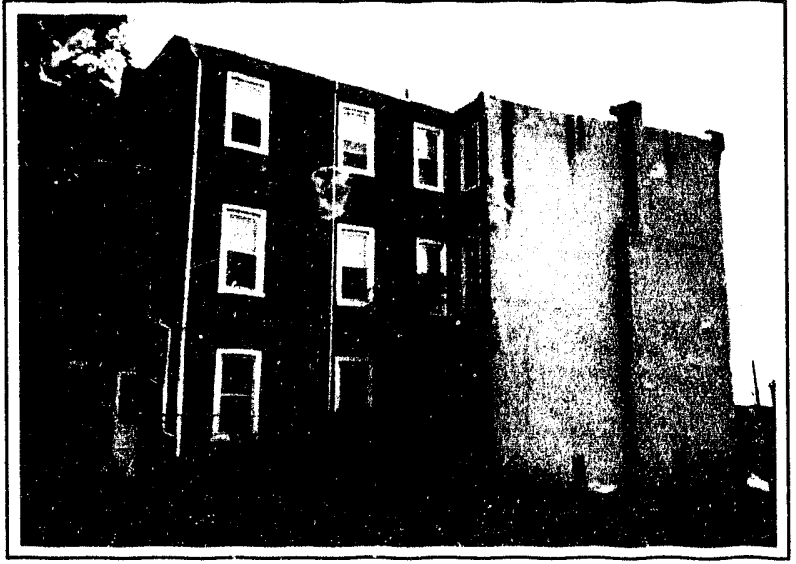

Newly missing nextdoor neighbor causes major air infiltration. 


\section{B. Sources of Funds}

To implement the Program, DOE provides money to State Weatherization Agencies, more than 80 percent of which are located within executive departments responsible for human services, community development, or economic development. In turn, these agencies allocate funds to local agencies, of which 81 percent are private, nonprofit Community Action Agencies. Most of the rest are local or county governmental agencies and Native American tribes. The weatherization work is done by employees of these local agencies or by contractors.

Although other organizations fund and implement low-income weatherization programs, DOE has been the dominant source of funding for low-income weatherization, providing 45 percent of total funding between 1978 and 1989 and a comparable level in recent years. There was more investment in low-income veatherization in the late 1980 s than in earlier years, but public funding levels have tapered off since then. More homes have been weatherized in cold states than in hot states, which partly reflects the formula used to allocate DOE's funds. The formula weights heating degree days more heavily than cooling degree days. On a national level, fund-

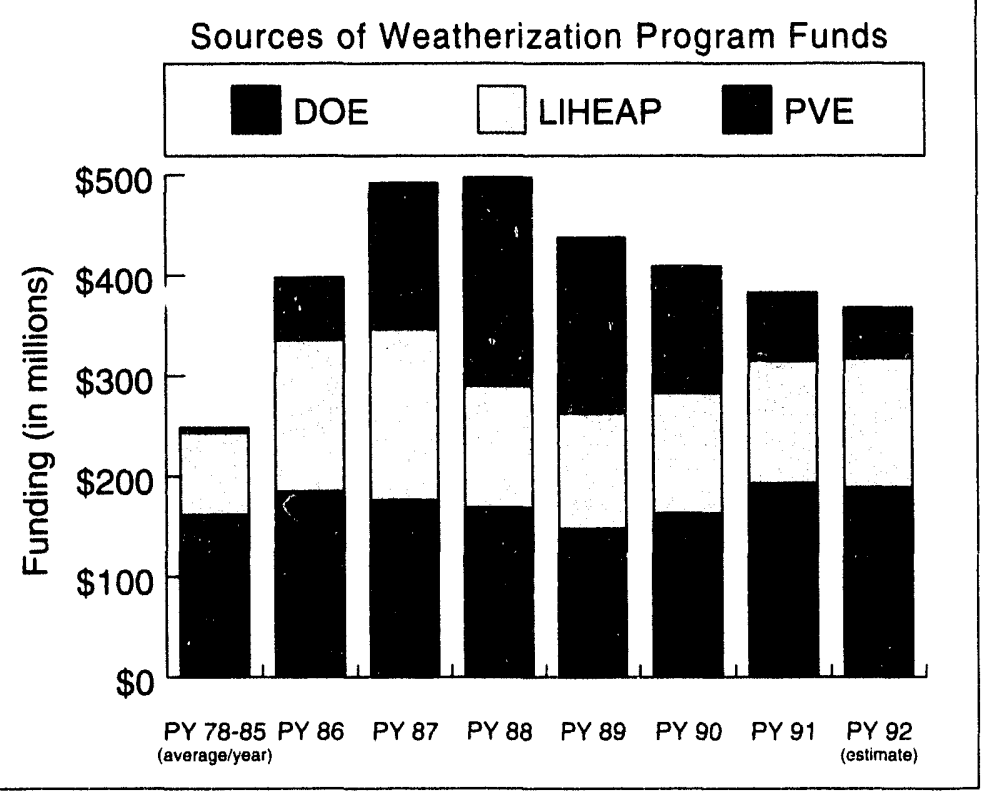

Three Major Sources of Weatherization Program Funds, 1978 to 1992. ing for all low-income weatherization activities in 1989 totaled $\$ 477.5$ million, of which the largest single component was DOE funds of $\$ 149.7$ million (31 percent).

Another major source of weatherization resources is the Low-Income Home Energy Assistance Program (LIHEAP), administered by HHS. Since 1982, states have had the flexibility to allocate up to 15 percent of LIHEAP funds (now 25 percent after receiving a waiver) to energy conservation measures. LIHEAP funding peaked in 1987 and has since declined.

A third major source of weatherization money is the Petroleum Viulation Escrow (PVE) Fund. These funds come from legal penalties assessed against oil companies convicted of violating price controls. The exhaustion of PVE funds devoted to low-income weatherization on a one-time basis is the most dramatic cause of the decline in total weatherization funding from 1987 to 1992 . State program managers indicate that total funding for low-income weatherization has dipped 30 to 40 percent since 1990 , primarily because of the exhaustion of PVE funds.

Utilities provided 9.6 percent of funding available for low-income weatherization between 1978 and 1989; utility programs and funding were responsible for 22 percent of all units weatherized. During the 12 year period, 49 utilities spent $\$ 418$ million on energy measures but invested only about one-third as much per unit as the DOE Weatherization Program. A small amount of funding for lowincome weatherization comes from miscellaneous other sources, including owners of rental housing weatherized under the Program and state weatherization programs, which in some cases emphasized comprehensive home repair or heating system retrofits. 
MOBILE HOMES

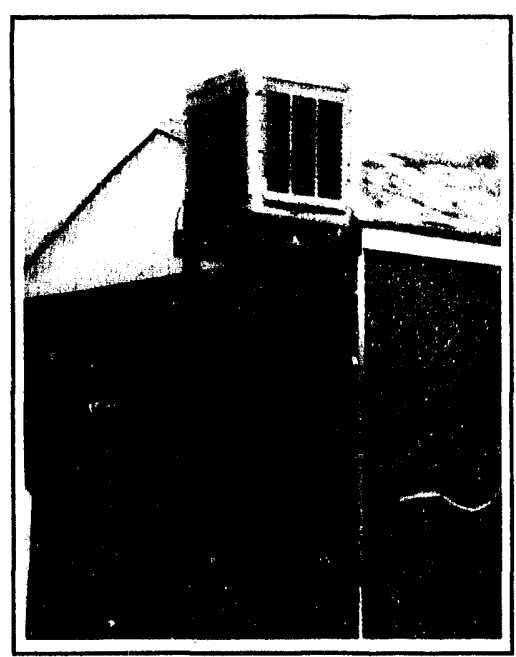

Evaporative chillers (swamp coolers) often mean large leaks.

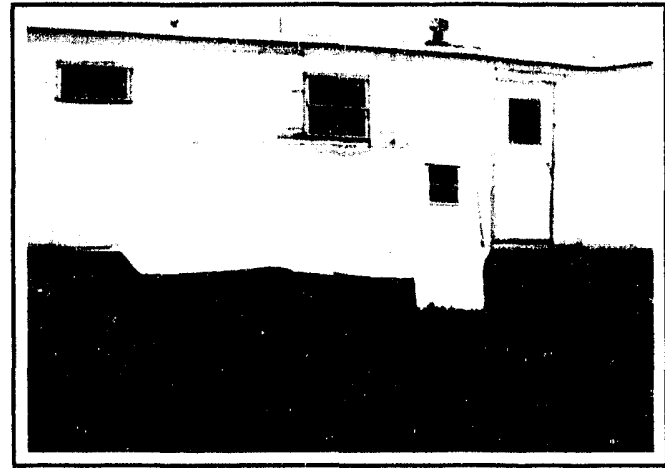

New doors and windows sometimes save energy, but air sealing ducts in mobile homes are usually a more cost-effective retrofit.

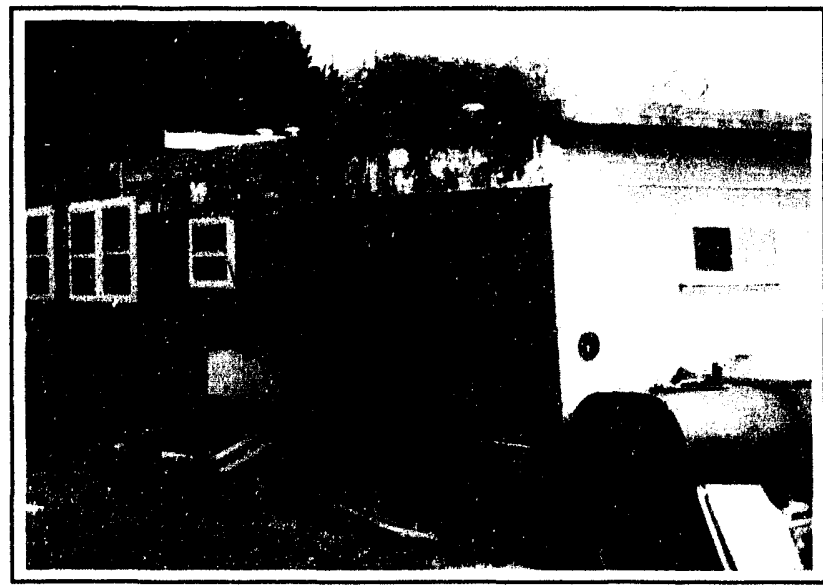

Very poor insulation causes major problems with mobile homes built before HUD's energy standards were adopted in 1976.
Due to the economic realities of affordable housing, many low-income families live in mobile homes. Weatherizing mobile homes in the hot climate zone constitutes at least a quarter of all work in many agencies.

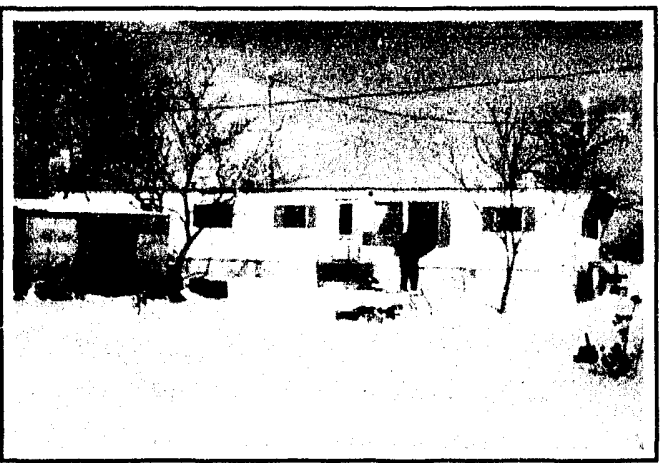

This home used over $\$ 1,000$ of fuel oil per heating season before weatherization tightened it up and installed a more efficient oil burner.

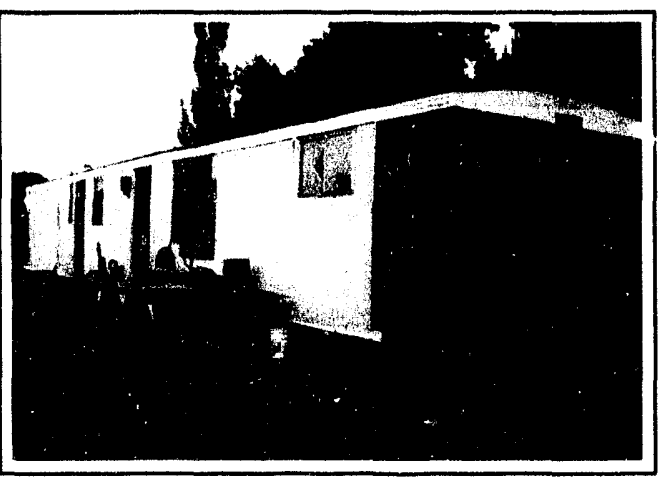

Mobile homes with poor foundations often develop major structural problems.

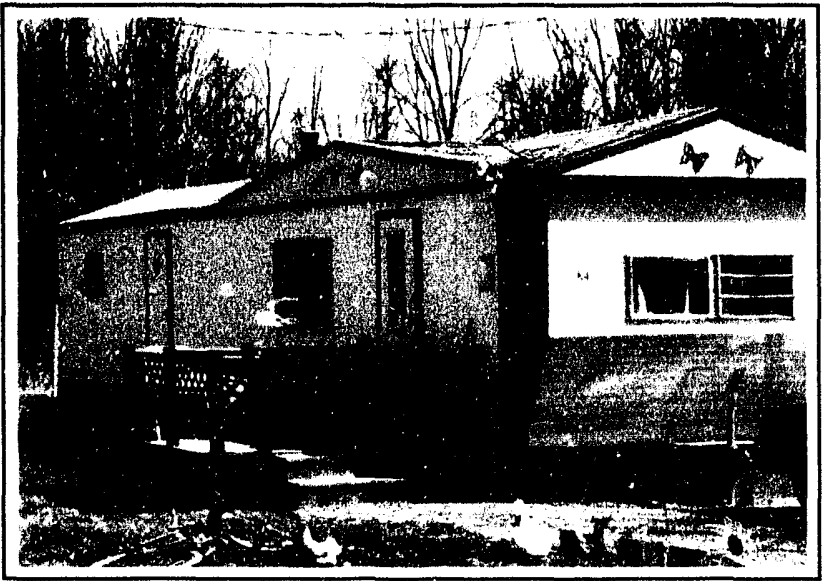

Skirting under a mobile home is not as important for the heating bill as belly board insulation, which can be blown in by weatherization crews. 


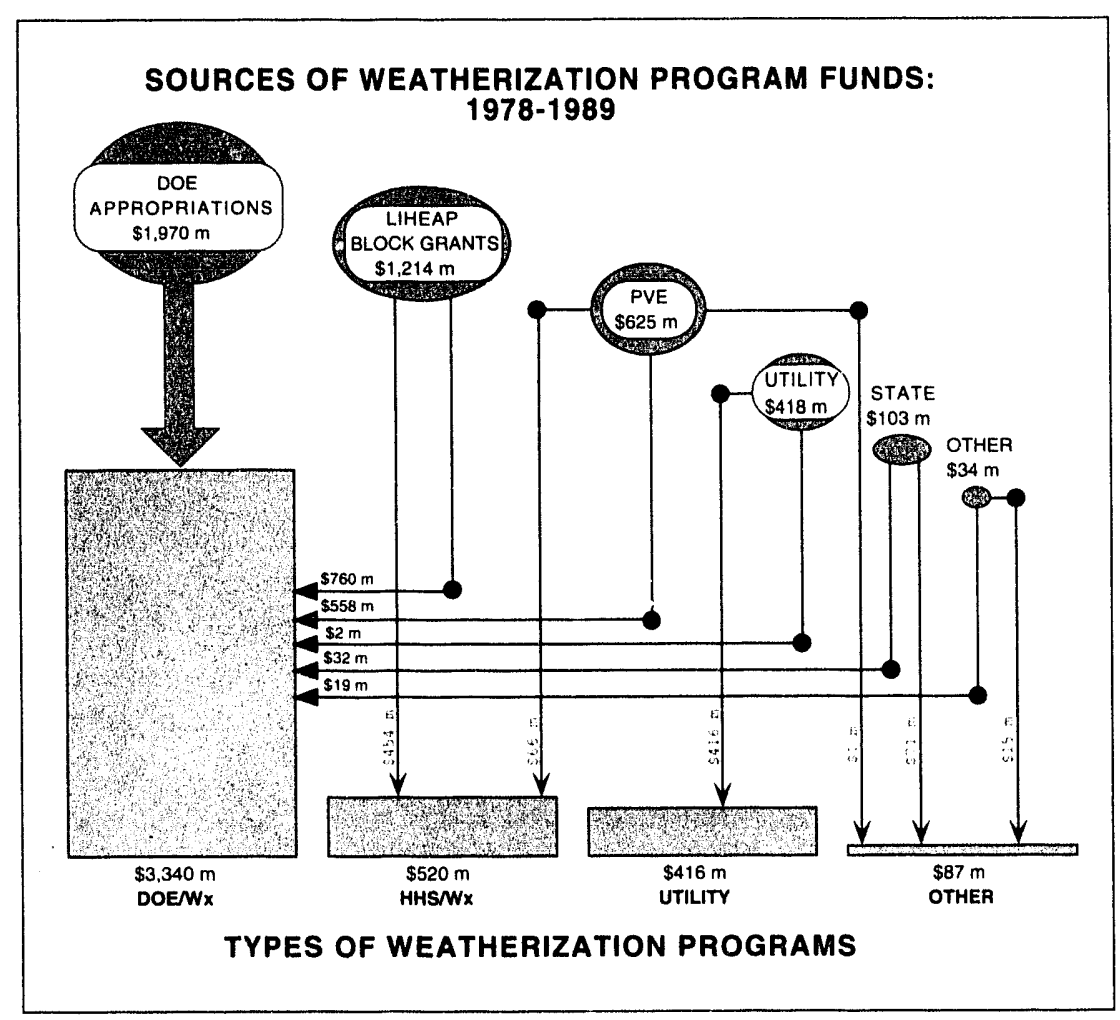

\section{Uses of Funds: DOE Sets the Pace}

Regardless of its source, most funding for low-income weatherization has been spent according to DOE's Weatherization Assistance Program rules. By law, all funds appropriated to the Program by DOE are governed by $D O E$ rules and regulations. In contrast, funds appropriated by LIHEAP can be spent by that program's much broader guidelines, which have allowed, for example, greater expenditures on furnace and boiler retrofits and replacements. Similarily, utility low-income DSM programs and state funding for weatherization can be spent as the funding agency deems appropriate.

In practice, 77 percent of all low-income weatherization money spent in the 12-year period between 1978 and 1989 was guided by DOE rules and procedures. Only 12 percent was spent in programs under LIHEAP regulations. The fact that the vast majority of nonDOE funds have been channeled through the

All Sources of Funding for Low-Income Weatherization: 1978-1989. Definitions of Program Types: DOE/WX = funds spent under DOE Weatherization Program rules and regulations. HHS/WX = funds spent under HHS LIHEAP guidelines and not DOE's rules and regula. tions. Utility $=$ funds spent in utility programs independent of DOE's rules and regulations. Other $=$ funds spent in state weatherization programs or other independent programs.
Program underscores DOE's central role in directing weatherization activities nationwide and indicates the importance the new Program rules will have in guiding future weatherization investments.

\section{DOE Outperforms Utilities}

In comparison to utility-sponsored low-income weatherization programs that invest comparable amounts per participant, the DOE Program has historically produced higher savings. Because most utility programs invest less than the DOE Program, there are only a few evaluations of utility low-income programs that invest comparable amounts in similar measures.

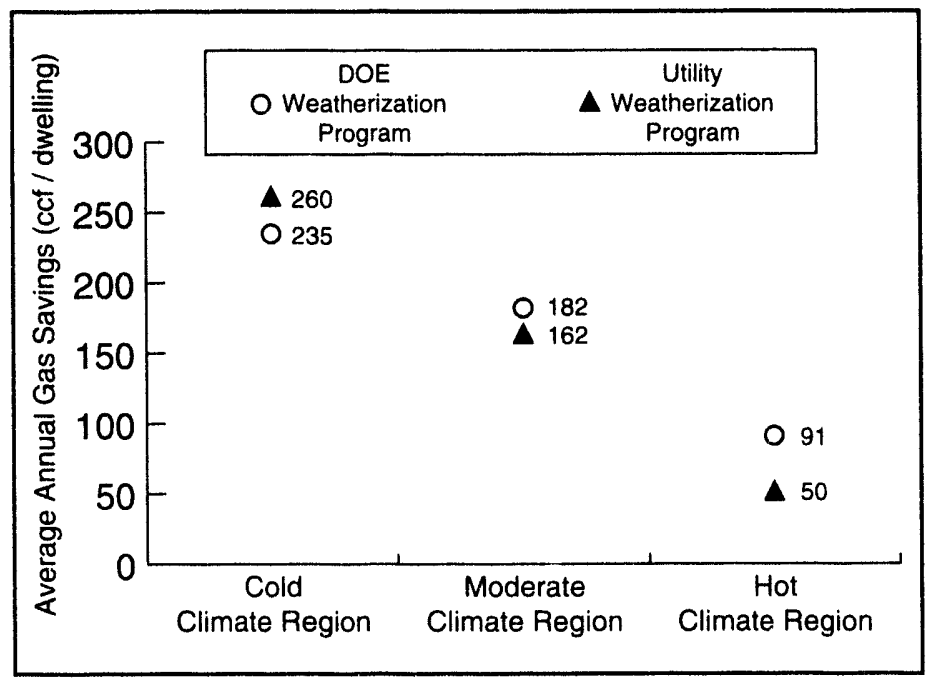

DOE Outperforms Utility Weatherization.
In the cold region, the weatherization programs of ten Wisconsin utilities were evaluated over two different periods. Although they produced slightly higher savings on average than the DOE Program, the average cost of weatherization was higher, thus making the DOE Program more cost-effective. In the moderate region, the DOE Program produced about 50 percent more savings (and invested somewhat more per dwelling) than a set of utility programs that operated throughout Ohio; it produced slightly less savings than another Ohio program that operated in 1990-91 at a slightly higher cost per dwelling. The cost-effectiveness of the DOE and both utility programs was about the same. In the hot region, the DOE Program produced almost twice the savings of a utility program that operated in California. Although the utility invested less per weatherized uwelling than did the DOE Program, the DOE Program in the hot region in 1989 was more cost-effective, with a lower cost of conserved energy. 


\section{DOORS AND WINDOWS}

Although most dwellings require air sealing, insulation, furnace retrofits, and at least minor repair work, exactly which tactics to employ is a Jecision that depends on the circumstances of the dwelling, the funding of the agency, and the know-how of the auditor and crews. This evaluation, plus testimony from experienced practitioners in the field, has shown that cookbook procedures employed in the early days of the Programweatherstripping, caulking, and storm windows-were only marginally effective. Audits using advanced diagnostics direct crews to the real problems in a dwelling and usually result in more cost-effective work.

Window and door repair is a necessary part of most weatherization operations, but many agencies in the moderate and cold climate areas have abandoned the practice of routinely installing storm windows and exterior doors because they have found these measures do not save as much as many other less costly conservation measures. In less severe climate areas, storm windows and exterior doors still play a large role in weatherization operations, although this evaluation and others have shown that other measures are usually more effective and less costly.

Although this storm window is still functional, missing window trim and a rotten sill plate have done substantial damage. The sash weight is visible from the outside of this dwelling.
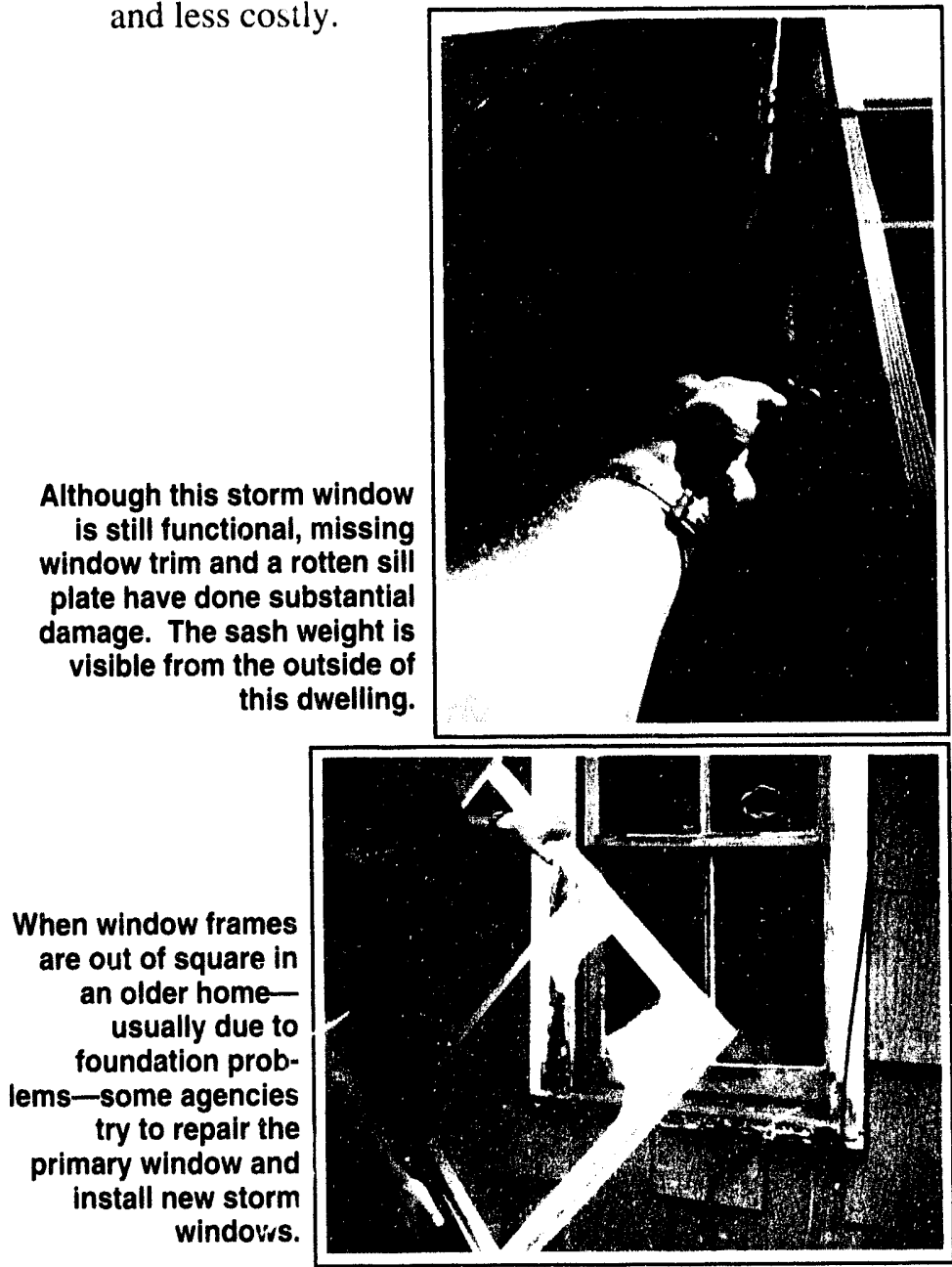

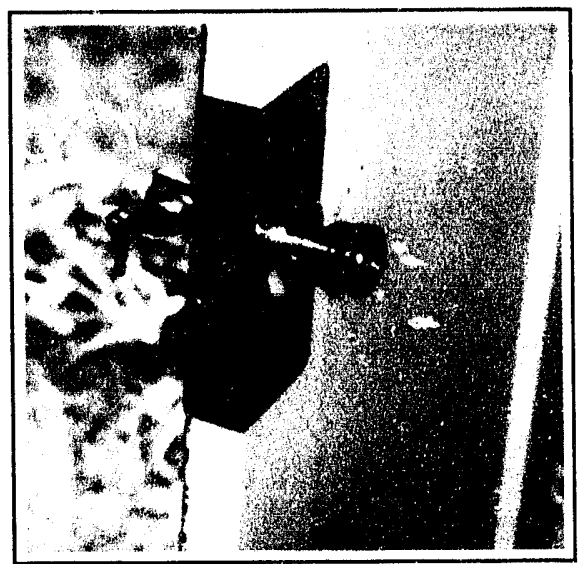

A new lock set is only marginally cost effective as a weatherization measure (it can aid in air sealing), but since it supplies a measure of security, this repair can be the most important one for a client. Sometimes a new door performs a similar security function.
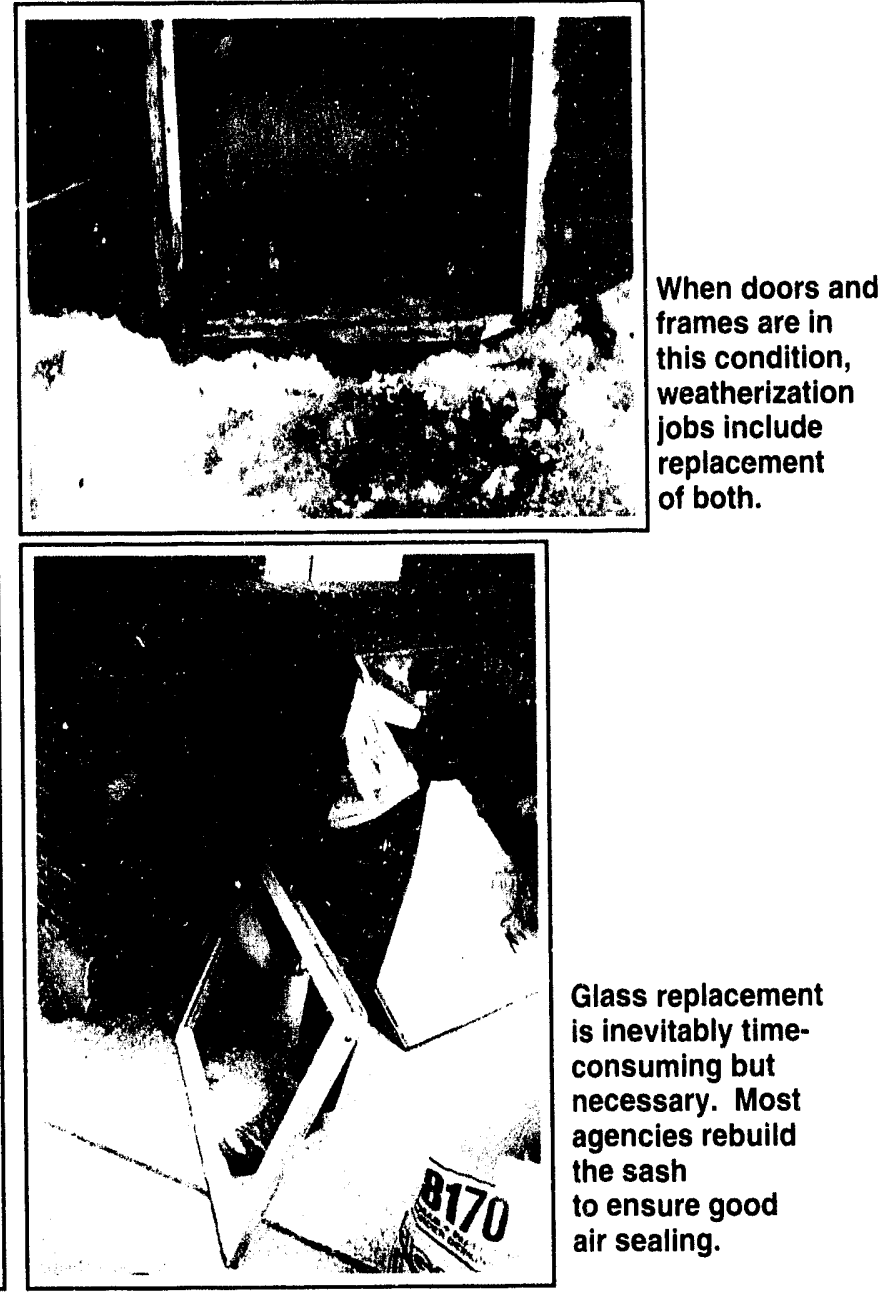

Glass replacement is inevitably timeconsuming but necessary. Most agencies rebuild the sash

to ensure good air sealing.

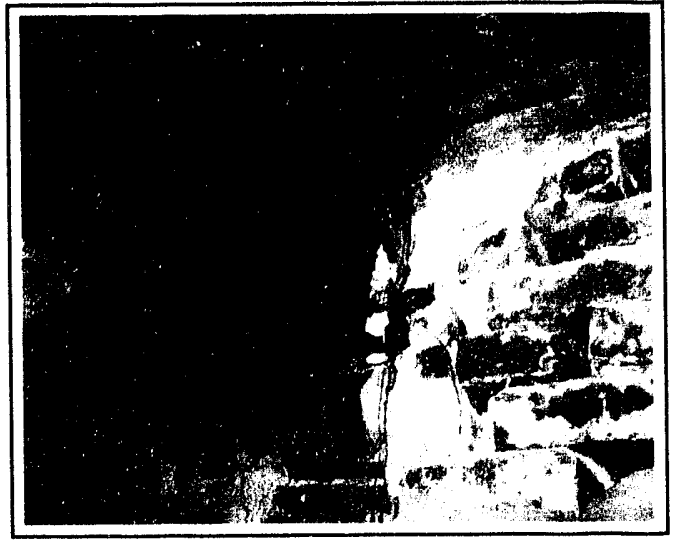

This basement window will be replaced by fixed-board insulation sealed in place by foam. 


\section{THE EVALUATION PROCESS}

The National Weatherization Evaluation is the first comprehensive evaluation of the Weatherization Assistance Program since 1984 (when the 1981 Program was evaluated). The evaluation was designed to accomplish the following goals:

- estimate energy savings and cost effectiveness;

- assess nonenergy impacts;

- describe the weatherization network;

- characterize the eligible population and resources; and

- identify factors influencing outcomes and opportunities for the future.

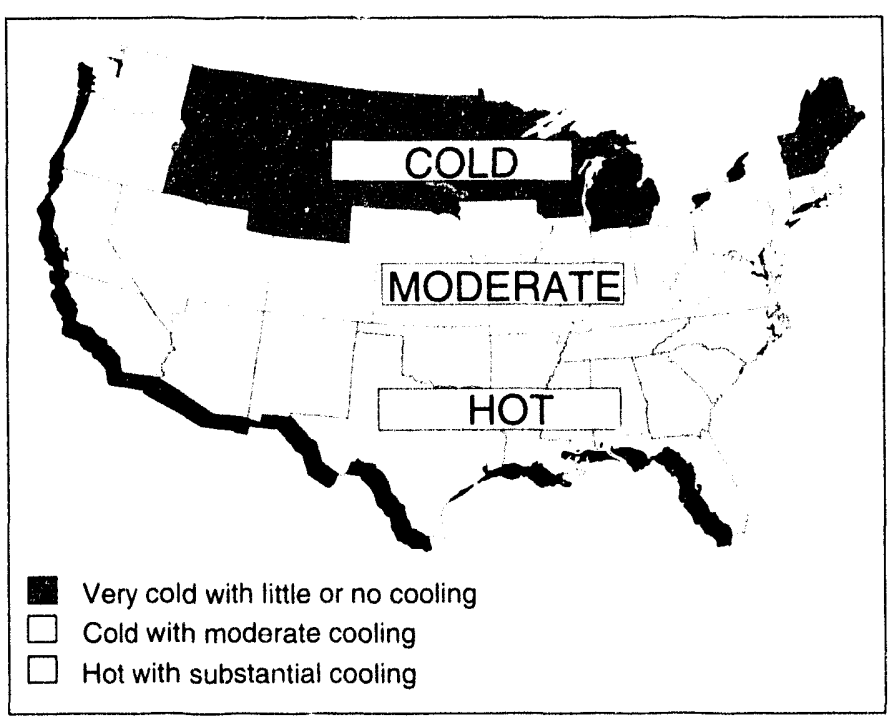

The National Weatherization Evaluation's Three Climate Regions.
Working groups with more than 30 nationally known evaluation specialists and conservation program professionals were formed to help define these goals. They gave guidance to the ORNL evaluation team in planning five major studies and in reviewing draft reports. The five studies were as follows:

Single-Family Study - this study estimates the national savings and cost-effectiveness of weatherizing single-family and small multifamily dwellings that use natural gas or electricity for space heating.

Fuel-Oil Study - this study estimates the savings and cost-effectiveness of weatherizing single-family homes in nine northeastern states that use fuel oil for space heating.

Multifamily Study - this study describes the measures used, resources employed, and challenges faced in weatherizing large multifamily buildings.

Network Study - this study characterizes the weatherization network's leveraging, capabilities, procedures, staff, technologies, and innovations.

Resources and Population Study - this study profiles low-income weatherization resources, the weatherized population, and the population remaining to be served.

As of October 1993, key findings from each of these studies are available. Three major reports have been published, and four additional reports have been drafted and are under review. (References to these reports are at the end of this document.)

As a national program, weatherization incorporates considerable diversity that springs in large part from regional differences. Therefore, evaluation results are presented both in aggregate and for three climate regions: cold, moderate, and hot. The Single-Family and the Fuel-Oil Studies both compared the performance of randomly selected samples of weatherized dwellings with samples of similar dwellings that were not weatherized. Appendix A provides further information on the evaluation design and data collected by these two impact studies. 


\section{AIR INFILTRATION/EXFILTRATION}

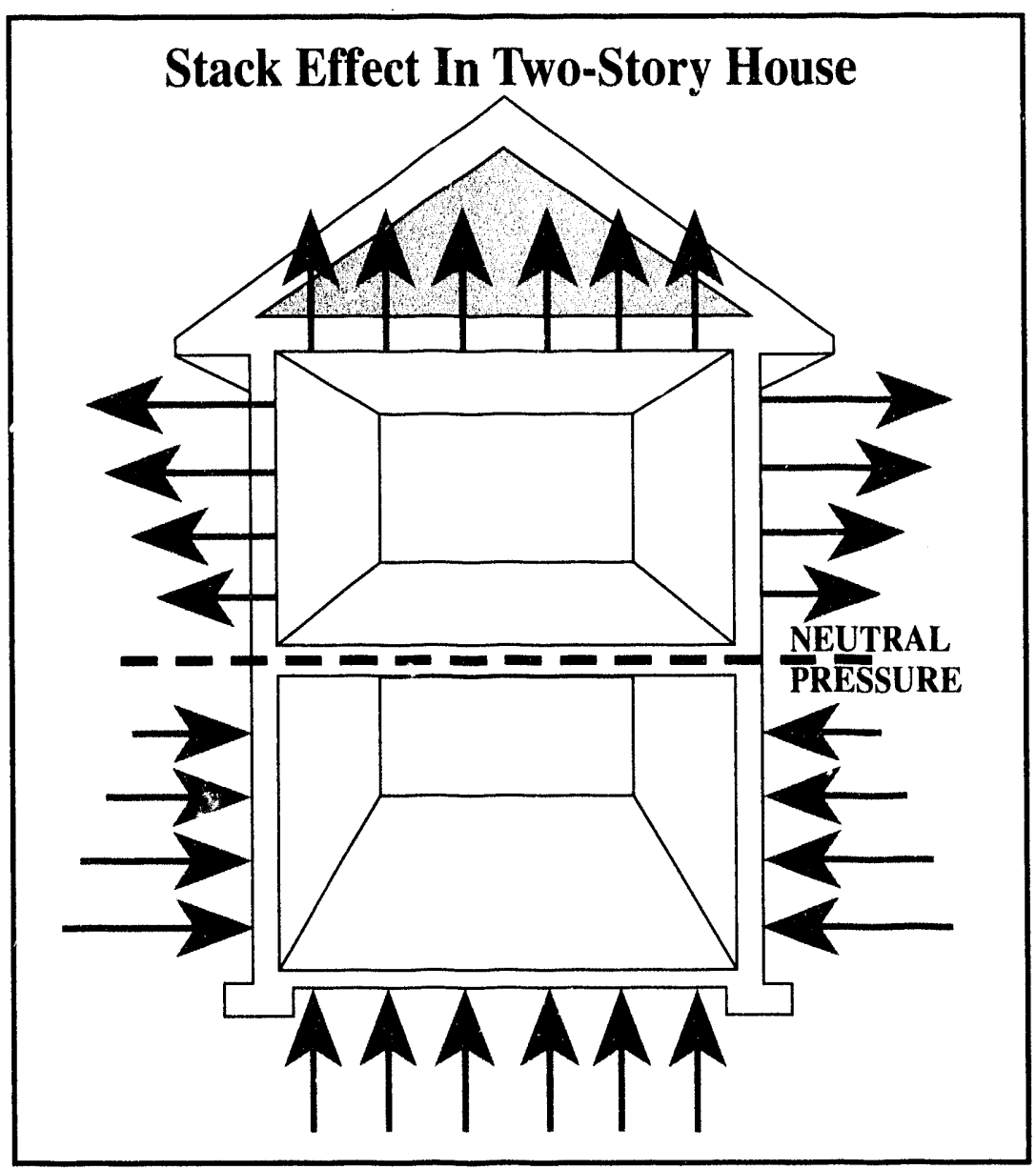

Very leaky houses are uncomfortable and have high energy bills, so finding and curing infiltration problems is a high priority for weatherization operations. The rate of air infiltration in a home depends on many factors, the most important being the size and location of holes in the thermal envelope and the difference in temperature between inside and outside. Warm air inside a dwelling gives rise to "stack effect" infiltration as warm air tries to escape from the top of the envelope, bringing in cold air at the bottom. Wind and leaks in duct systems can also have a major effect on infiltration, but these effects are not usually as constant over the heating season as is stack-effect infiltration, which is at its worst on coldest days.

Note that in the middle of the heated envelope there is a neutral pressure zone where neither infiltration nor exfiltration occurs due to stack effect. This explains $w$ ! caulking and weatherstripping in mid-envelope tends to save less energy than car ful attention to the bottom and top of the envelope, where these natural driving forces are greater. 


\section{FINDINGS}

\section{A. Diversity of Dwellings and Agencies}

Perhaps the most striking finding of the evaluation is the diversity among local weatherization agencies acruss the country. Some agencies weatherize 15 homes in a year; others weatherize thousands. Some agencies achieve savings of 30 to 40 percent of preweatherization consumption. Others produce no measurable savings. Some agencies employ state-of-the-art procedures, use a variety of funding and technical resources, and perform sophisticated self-evaluations. Others follow the same procedures year after year, do not evaluate their impacts, and rely entirely on DOE for funding.

The housing stock addressed by the Program also is diverse. Most lowincome people live in homes built in the decades of cheap energy. Poor insulation and leaky construction have wasted energy from the start, and, inevitably, aging makes structures more energy inefficient, more expensive to heat, and often cold, unsafe. and unhealthy. Among the dwellings weatherized in 1989,39 percent were more than 50 years old. On the other hand, 12 percent were less than 10 years old.

Dwellings have been classified into five types. Each type has unique weatherization needs.

Vear of Construction of Dwellings Weatherized in 1989.

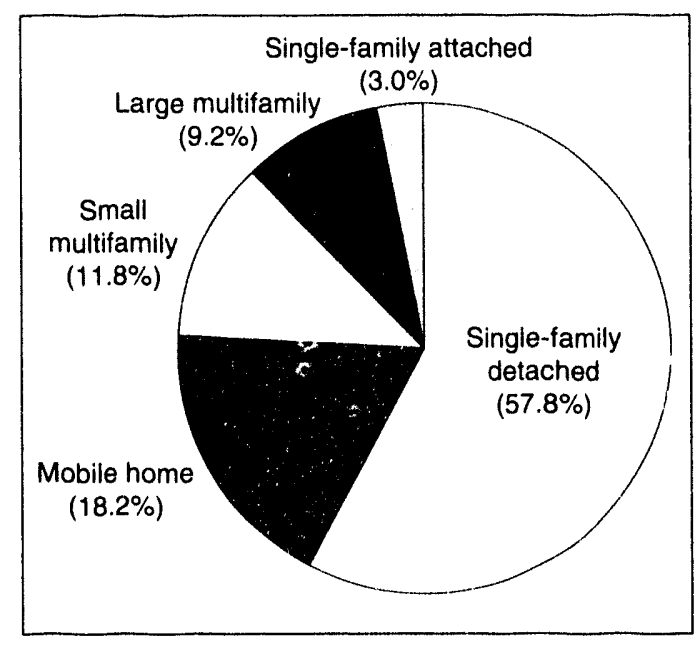

Types of Dwellings Weatherized in 1989.
Single-family detached homes are the dominant type of structure weatherized by the Program in 1989 (representing 58 percent of the total). Half of these single-family detached units heat primarily with natural gas, and only 10 percent heat with electricity. Elderly occupants reside in 40 percent of these houses, a higher concentration than for any other dwelling type. The vast majority these houses ( 73 percent) are owner-occupied.

Single-family attached dwellings (often called row homes) comprise the smallest housing-type category ( 3 nercent of the weatherized population). Almost all are centrally heated ( 93 percent). As a class, these are the oldest buildings, with a mean age of 56 years. They also tend to have higher-income occupants and are located almost entirely in the moderate region.

Mobile homes comprise 18 percent of the weatherized population. They are by far the "newest" units, with an average age of only 17 years. They are more likely than any other housing to be heated with a nonmetered fuel (mainly propane). They are 78 percent owner-occupied and are occupied by individuals with the lowest incomes.

Small multifamily dwellings (those located in buildings with 2 to 4 units) comprise 12 percent of the weatherized population. They are heated primarily with natural gas ( 73 percent) and are typically renter-occupied ( 82 percent). Compared to single-family detached homes, they are only half as likely to have an elderly or handicapped occupant.

Large multifamily dwellings comprise 9 percent of the weatherized population and represent a distinct building type. They are located almost entirely in the moderate and cold regions (approximately half are located in New York City), and they tend to be older than the single-family dwellings weatherized by the Program ( 52 percent vs 38 percent were built bcfore 1940). They are almost all centrally heated by gas, electricity, or fuel cill. 


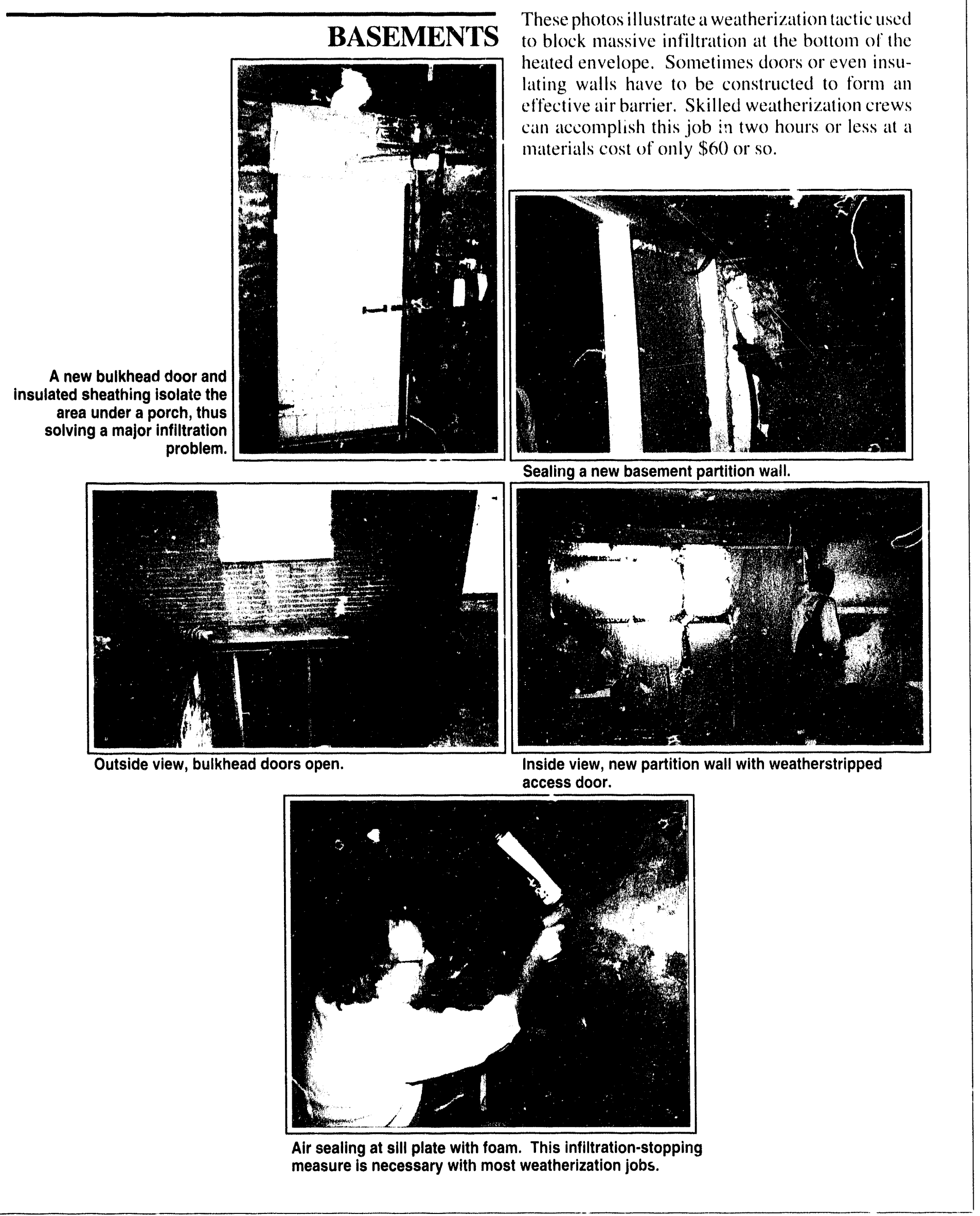




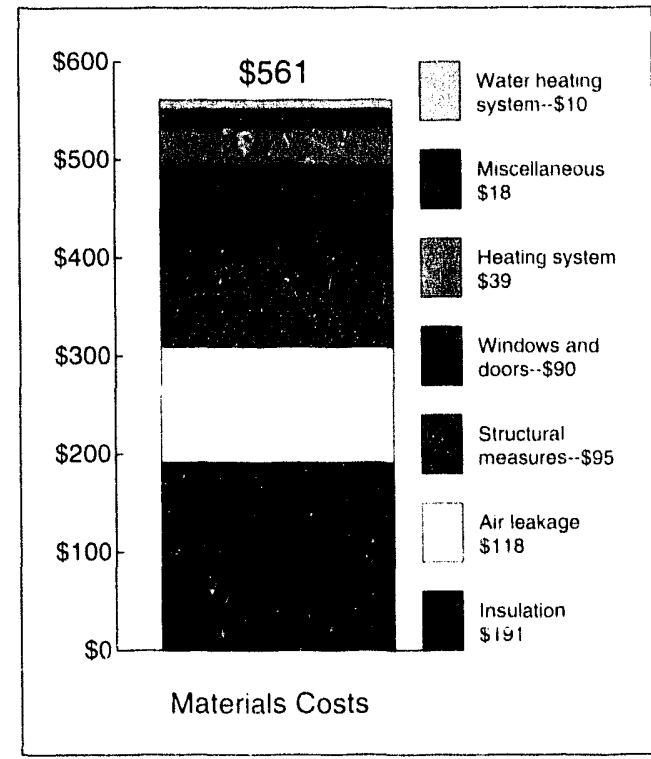

Cost of Materials to Weatherize a Typical Dwelling in 1989.

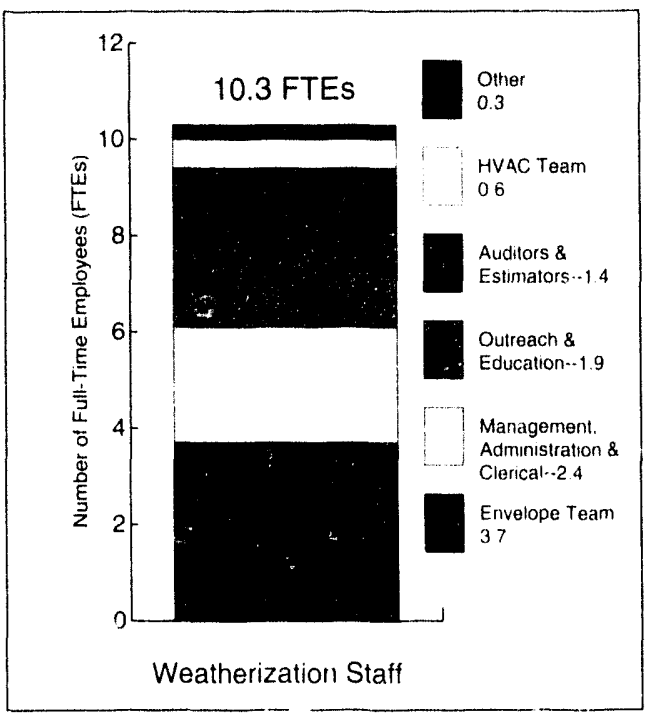

Weatherization Staff Employed by a Typical Agency in 1989.

\section{The Typical Dwelling}

The typical dwelling' weatherized by DOE's Program in 1989 was a $51-$ year-old, single-family detached dwelling in the moderate region with 1,193 square feet of huated space. The three-person household living in the house had an $\mathrm{i}$ :ome of $\$ 7,641$. Prior to weatherization, the typical dwelling was heated by an inefficient gas furnace (with a 75 percent steady-state efficiency). The dwelling had significant air le; kage ( 1.3 air changes per hour) and limited, if any attic, wall, or floor insulation.

Weatherization for this dwelling consisted of installing insulation (primarily in the attic and walls), along with air leakage reduction and water heating system efficiency measures. Incidental repairs and health and safety measures were also performed. The dwelling received 28 crew hours of weatherization labor and $\$ 561$ of weatherization materials. After weatherization a quality control check was performed.

In the first year after weatherization, the typical dwelling saved 20.3 ecf of natural gas, or 15 percent of its preweatherization gas consumption and 21 percent of the gas it uses for space heating. Over the lifetime of the measures, the typical dwelling will save 4,060 cef of gals, or slightly less than four years' worth of home healing fuel.

\section{The Typical Agency}

The typical agency² involved in the Weatherization Assistance Program is located in the moderate region, and weatherized approximately 350 homes in 1989, most of which were single-family, detached dwellings heated primarily with natural gas. This definition of the typical agency excludes agencies in the less populous hot and coll climate regions, agencies that serve densely pepulated metropolitan areas. and small agencies that serve one or two rural counties.

Based on 1989 data, the typical agency is a Community Action Agency that receives weatherization funding of almost $\$ 600,00)$ from multiple sources, including DOE, PVE, and to a lesser degree LIHEAP. Operating two crews, the typical agency weatherizes nearly two homes each work day. The staff of 10 full-time employces includes energy auditors; envelope crews with a crew chief; client outreach and education staff; management, administrative, and clerical staff; and other technical and nontechnical staff, which may include a heating system specialist.

The typical agency also performs other services for about one-thirci of its weatherization clients, which might include installing smoke detectors or door locks. In addition, the typical agency refers about one-third of its clients to other public programs that offer such services as nutrition, health, fuel assistance, employment, and job training. 


\section{BLOWER DOORS}

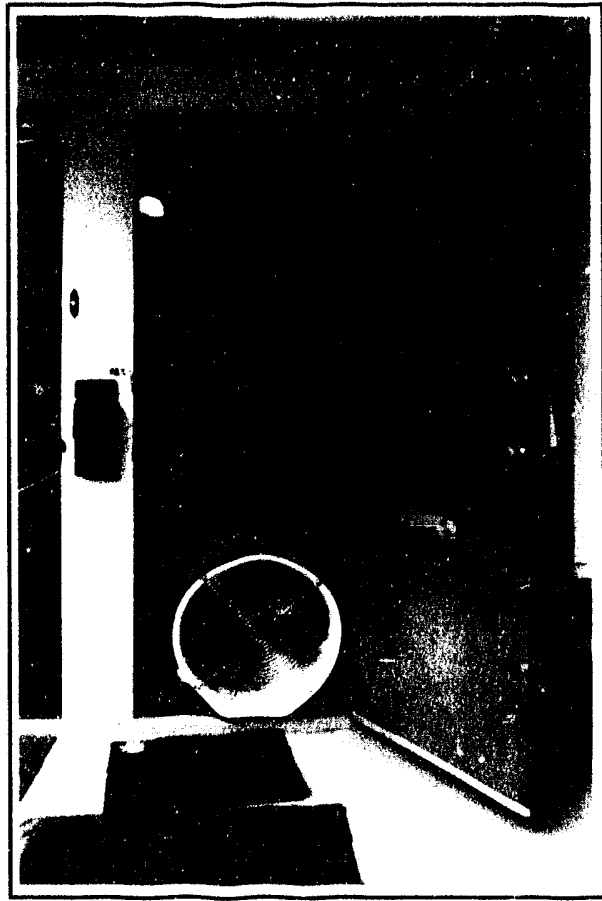

Blower door setup, outside view.

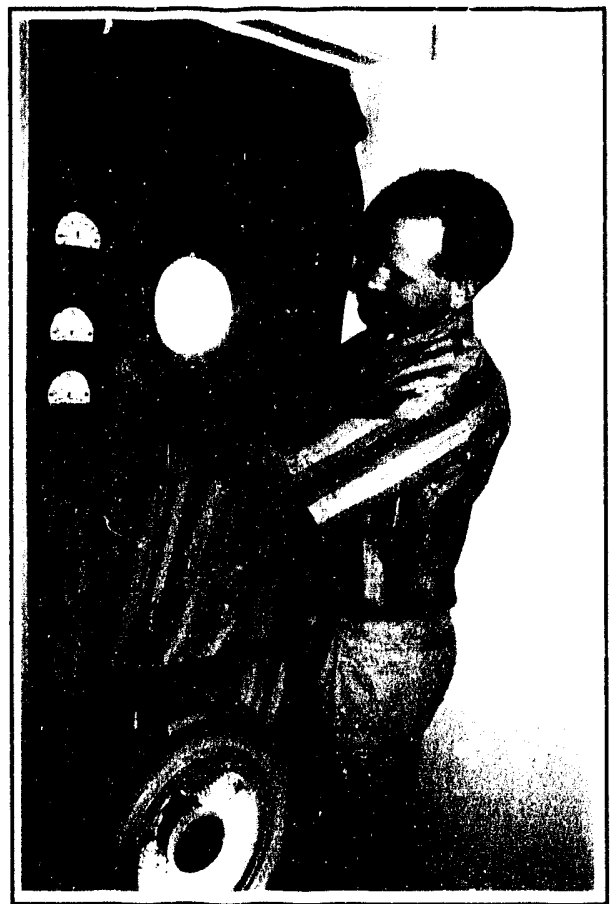

Blower door setup, inside view. The technician is zeroing the gauges, so as to measure both air flow and the insideoutside pressure difference caused by the blower door. The speed of the fan is adjusted using the control on top of the fan.
Blower doors are variable-speed fans equipped with a frame and shroud that permits them to fit inside a variety of door frames. Instrumentation includes pressure gauges that enable the operator to determine the flow of air through the fan as well as the pressure the fan induces on a dwelling. Since leakier houses require more air flow to induce a given pressure difference, blower doors can measure the relative leakiness of a house. When used as a diagnostic instrument. they can also reveal the location of many leaks, thus providing a clear target for air sealing.

When the job is partially or fully complete, blower doors also provide technicians with fast feedback on the effectiveness of their work, thus contributing to increased practical wisdom on the part of the technicians and to the overall professionalization and efficiency of the weatherization process itself.

Experience has shown that high preweatherization blower door readings of flow (at a standard pressure of 50 pascals, for example) are strongly correlated with success in air sealing, as revealed by substantially lower postweatherization blower door readings.

Significantly, blower doors are also useful in revealing what does not need to be done, allowing weatherization crews to concentrate on real problems. This observation illuminates critical features of the evolution of the weatherization program and building science.

Prior to the advent of blower door technology and the detailed analysis of patterns of convective energy losses, conventional wisdom held that most air leakage occurs toward the mid-height of the conditioned envelope, primarily through doors and windows. Accordingly, application of weatherstripping and caulking in those areas was advocated in DOE instructions and related publications and was widely practiced by weatherization technicians and others. In the early days of blowerdoor-aided diagnostics and air sealing-which for most weatherization agencies included the period of this evaluation-these practices continued. In fact, blower doors do reveal leaks from doors and windows, although their effects are amplified, since small areas result in high-velocity aircurrents. Gradually, however, it was 'iscovered that leakage from doors and windows represents a relatively small percentage of convective losses in most dwellings, and that genuinely serious leaks tended to occur at the bottom and (especially) the top of the conditioned envelope. Accordingly, careful air sealing in attics and basements is increasingly practiced by weatherization crews in most areas of the country. The use of blower door technology should be periodically evaluated at the local level to ensure that the technology promotes cost-effectiveness in various circumstances. 


\section{B. Program Benefits}

\section{National Energy Savings}

During Program Year (PY) 1989, the Progran weatherized 198,000 single-family or small multifamily homes, resulting in net energy savings during the following year equivalent to 601,000 barrels of oil, or almost 1,650 barrels of oil per day. ${ }^{3}$ Over the estimated 20-year lifetime of the weatheriza-

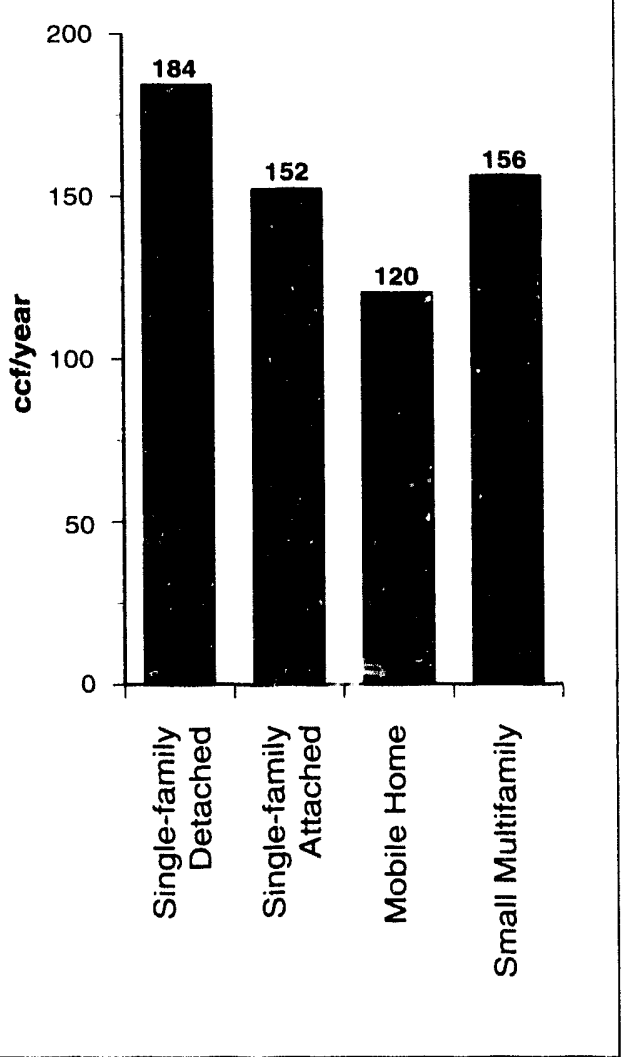

Gas Savings by Types of Dwellings Weatherized in 1989. tion measures, net savings from Program expenditures in 1989 are projected to be 69.7 trillion Btus, the energy equivalent of 12 million barrels of oil. These estimates are based on measured reductions in the use of primary heating fuels after weatherization. Savings of supplemental heating fuels were not measured.

Gas-heated dwellings account for 50 percent of the dwellings weatherized by the Program in 1989. It is estimated that the Program, which addresses only space heating and sometimes water heating energy efficiency, saved 18.3 percent of the gas used for space heating. This represents 13.0 percent of total gas use, including water heating, cooking, and other gas-appliance uses. Variations in savings by dwelling type were significant. For example, singlefamily detached dwellings (the dominant dwelling type served by the Program) saved over 50 percent more natural gas per dwelling than did mobile homes.

Electrically heated homes represent only 10 percent of the dwellings weatherized under the Program during 1989. Weatherization of these dwellings saved 35.9 percent of the electricity used for space heating. This represents 12.2 percent of total electricity use. As with gas-heated homes, both single-family detached and small multifamily dwellings saved more electricity than did mobile homes.

The Fuel-Oil Study showed that an average single-family dwelling located in the Northeast and heated primarily by fuel oil saved 160 gallons of fuel oil in the first year following weatherization. This is equivalent to 22.4 million Btus, or 17.7 percent of

Net energy savings for single-family and small multifamily dwellings weatherized in 1989

\begin{tabular}{|l|c|c|c|}
\hline Primary heating fuel & $\begin{array}{c}\text { Percentage of } \\
\text { space heat }\end{array}$ & $\begin{array}{c}\text { Percentage of } \\
\text { total fuel use }\end{array}$ & $\begin{array}{c}\text { Net savings } \\
\text { (M/Btu/year) }\end{array}$ \\
\hline Natural gas & 18.3 & 13.0 & $17.3 \mathrm{MBtu} /$ year \\
\hline Electricity & 35.9 & 12.2 & $18.9 \mathrm{MBtu} /$ year \\
\hline Fuel oil (Northeast) & 17.7 & 17.7 & $22.4 \mathrm{MBtu} /$ year \\
\hline All fuels* & 18.2 & 13.5 & $17.6 \mathrm{MBtu} /$ year \\
\hline *Includes estimates for propane, wood, kerosene, coal, and other fuels.
\end{tabular}
total fuel-oil use. (Fuel oil is generally used only for space heating.)

Measured savings for gas, electricity, and fuel oil were combined with estimates of energy savings for dwellings that heat primarily with other fuels such as propane, wood, kerosene, and coal. The average savings for all single-family and small multifamily dwellings weatherized in 1989 was estimated to be 17.6 million Btus per year, 18.2 percent of the energy used for space heating and 13.5 percent of total energy use. 


\section{DENSE-PACK CELLULOSE}

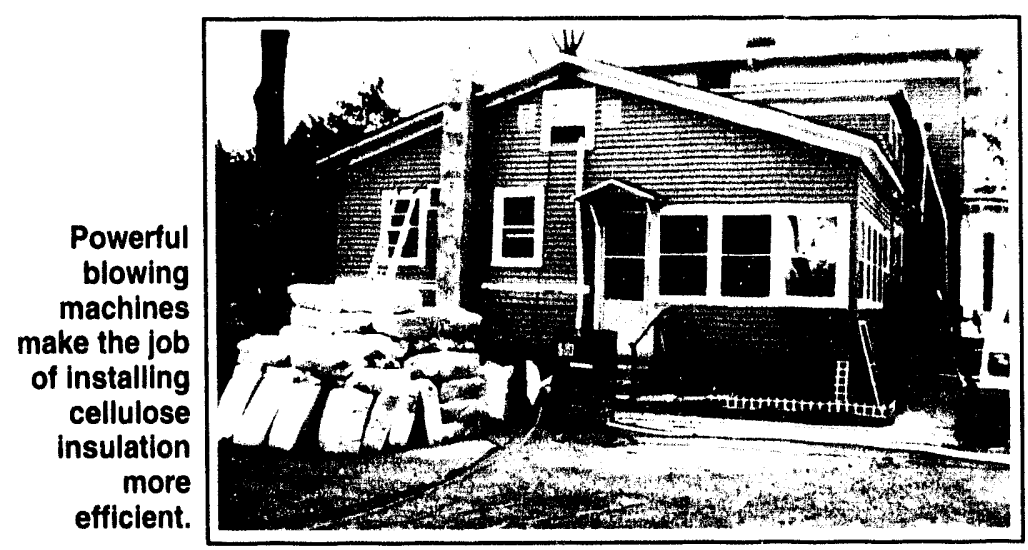

Installing cellulose at high density has been found to be a powerful technique for installing insulation and achieving air sealing at the same time. Many crews find that the infiltration rates of some houses can be cut in half without using a tube of caulk. The secret is careful installation of high-density cellulose in wall cavities (and other places where it really counts) with a tube inserted directly where the insulation needs to go-and using power blowing machines to pack it in tightly. In PY 1989, most agencies had not yet incorporated this technique into their weatherization operations, but more recent analyses conducted in this evaluation (the Fuel-Oil Study and the analysis of high-performing agencies) suggest that these newer measures save considerable energy.
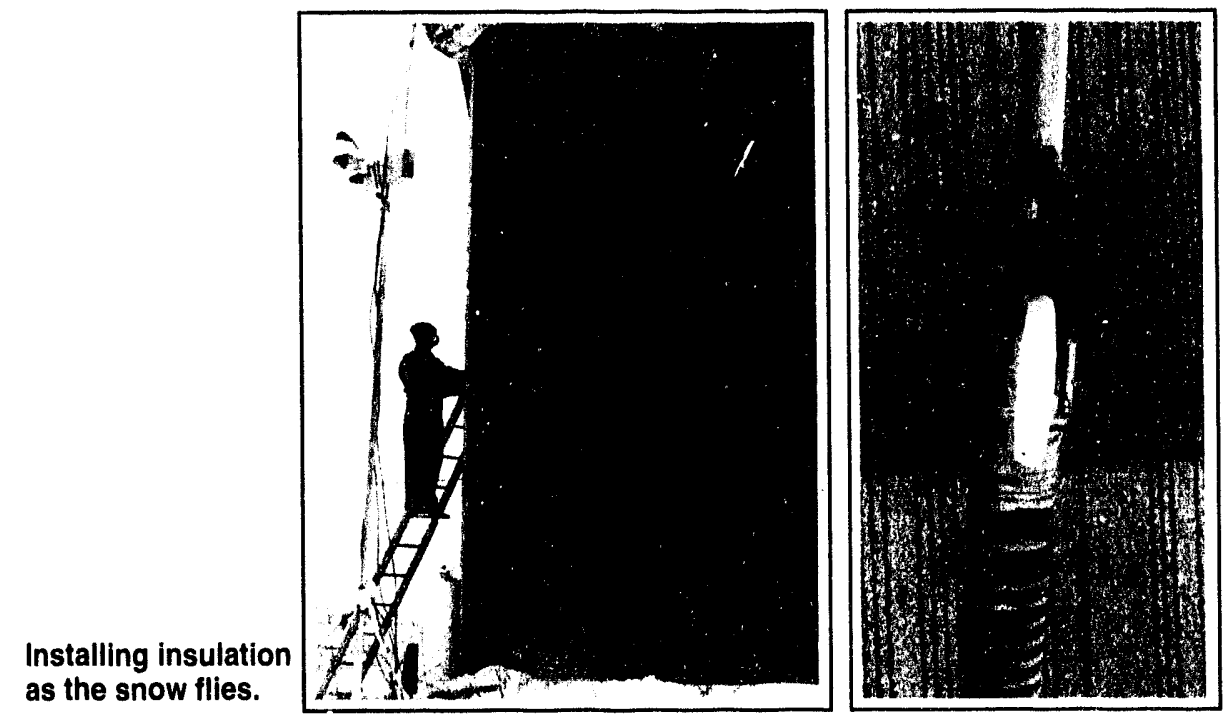

The small tube at the top is snaked into wall cavities, then slowly withdrawn as insulation fills them up. The result is a very tight fill.

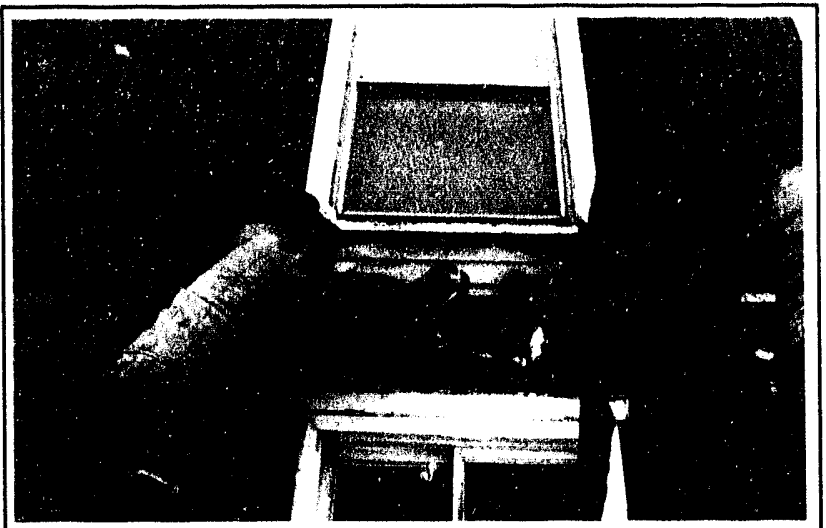

Preparation, insulation, and cleanup keeps two weatherization team members working for most of a day.

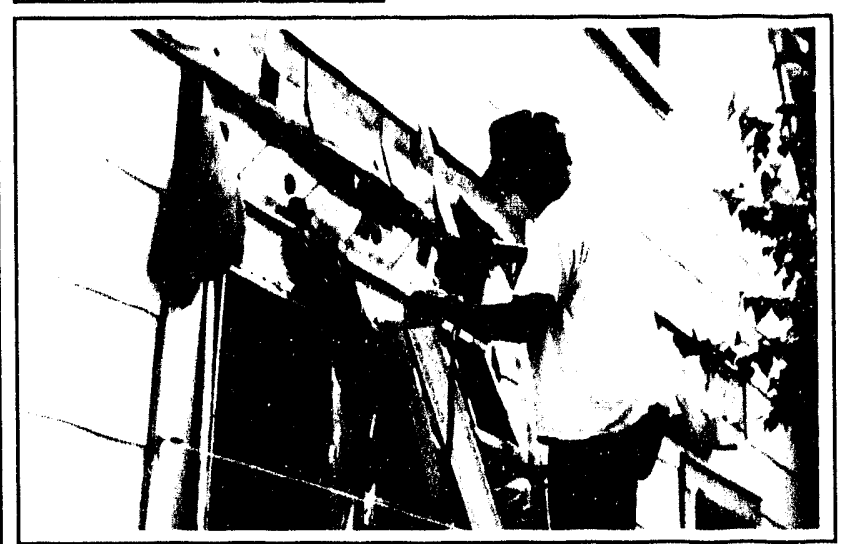

Wall preparation. Shingles are positioned for fast reattachment after insulation blowing. 


\section{Health, Safety, Jobs, and Environment}

For the purposes of the evaluation, selected nonenergy benefits were assigned a dollar value, but the methods used to estimate their value varied. Estimates of environmental benefits relied on a literature review and on information about the proportions of weatherized dwellings using various fuel types and the average savings of different fuels. Estimates of employment benefits combined a literature review with data on Program employment, the skill levels of workers, and managers' judgments concerning the job market for weatherization workers. Data on Weatherization Assistance Program expenditures for home repair were used to quantify the benefits associated with maintaining or enhancing property values and extending the lifetimes of dwellings. The monetary benefits of reducing the incidence of fires were quantified using iiisurance industry data. Estimates of reductions in arrearages were based on a literature review and data on payment histories collected on the dwellings included in the evaluation. For each benefit included in the estimate, we developed an averige value per weatherized dwelling.

Ultimately, the dollar value of nonenergy benefits resulting from the weatherization of single-family and small multifamily dwellings was estimated to be $\$ 976$. The following table gives a summary of the nonenergy benefits.

\begin{tabular}{|l|c|}
\hline \multicolumn{1}{|c|}{ Type of nonenergy impact } & $\begin{array}{c}\text { Value of the impact } \\
\text { per dwelling }\end{array}$ \\
\hline Increased property value & $\$ 126$ \\
\hline Rer'uced incidence of fire & $\$ 3$ \\
\hline Reduced arrearages & $\$ 32$ \\
\hline Federal taxes generated from direct employment & $\$ 55$ \\
\hline Income generated from indirect employment & $\$ 506$ \\
\hline Avoided costs of unemployment benefits & $\$ 82$ \\
\hline Environmental externalities & $\$ 172$ \\
\hline Total & $\$ 976$ \\
\hline
\end{tabular}




\section{ADVANCED AIR SEALING}

In the last several years, it has been shown that some previously ignored areas of dwellings can be potent sources of convective losses-and thereby offer good potential for savings if found and treated. As illustrated in the figures, these include interstices between floors, spaces between the conditioned envelope and such buffer zones as porches and garages, and areas between old and new portions of dwellings. The blower door, in conjunction with a gauge that measures differences in pressure, is a valuable tool in identifying leakage to or from these areas, helping both in identifying the magnitude of the leakage and in verifying when such measures as the blowing of high-density cellulose or other air-sealing measures will solve the problem. While only a few weatherization agencies have integrated these tests and tactics ini. routine operations, those which have done so achieve excellent savings.

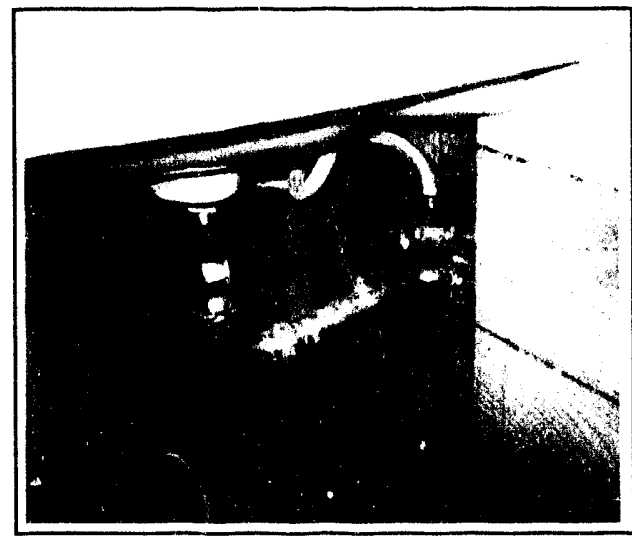

Note the infiltration area under the bathroom sink, which connects to the attic via a stud cavity in an interior wall.

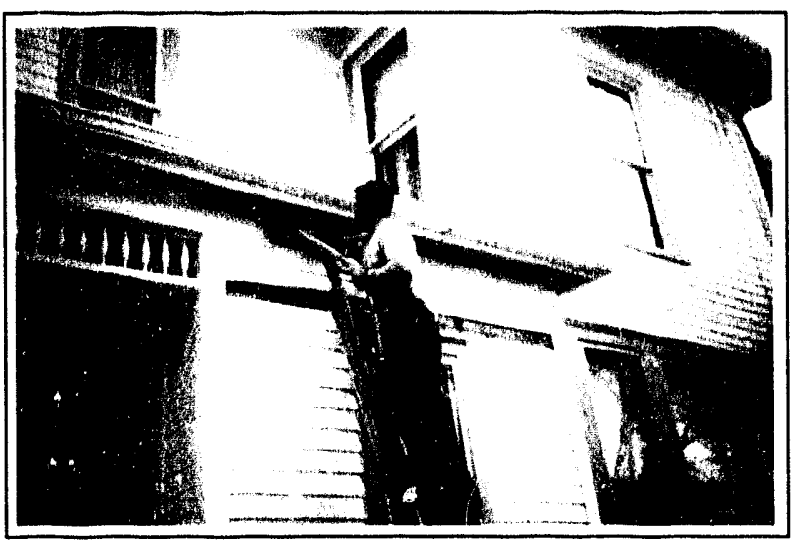

As revealed by a blower door and a pressure gauge in a test that takes only several minutes, the area under this porch is directly connected to the envelope through floor joists between the first and second floor. High-density insulation is being used to air-seal this largest hole in the dwelling.

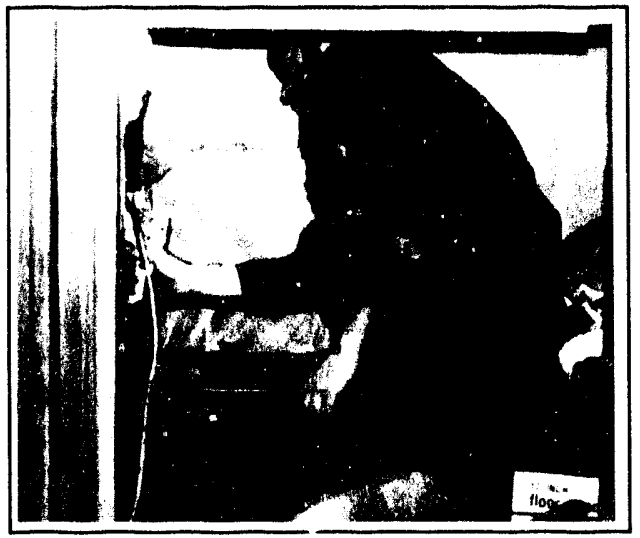

Air sealing a plumbing chase on the first floor that corresponds with both attic and basement. Sealing holes in inconspicious and hard-to-get-to places are frequently those which result in good, cost-effective weatherization jobs.

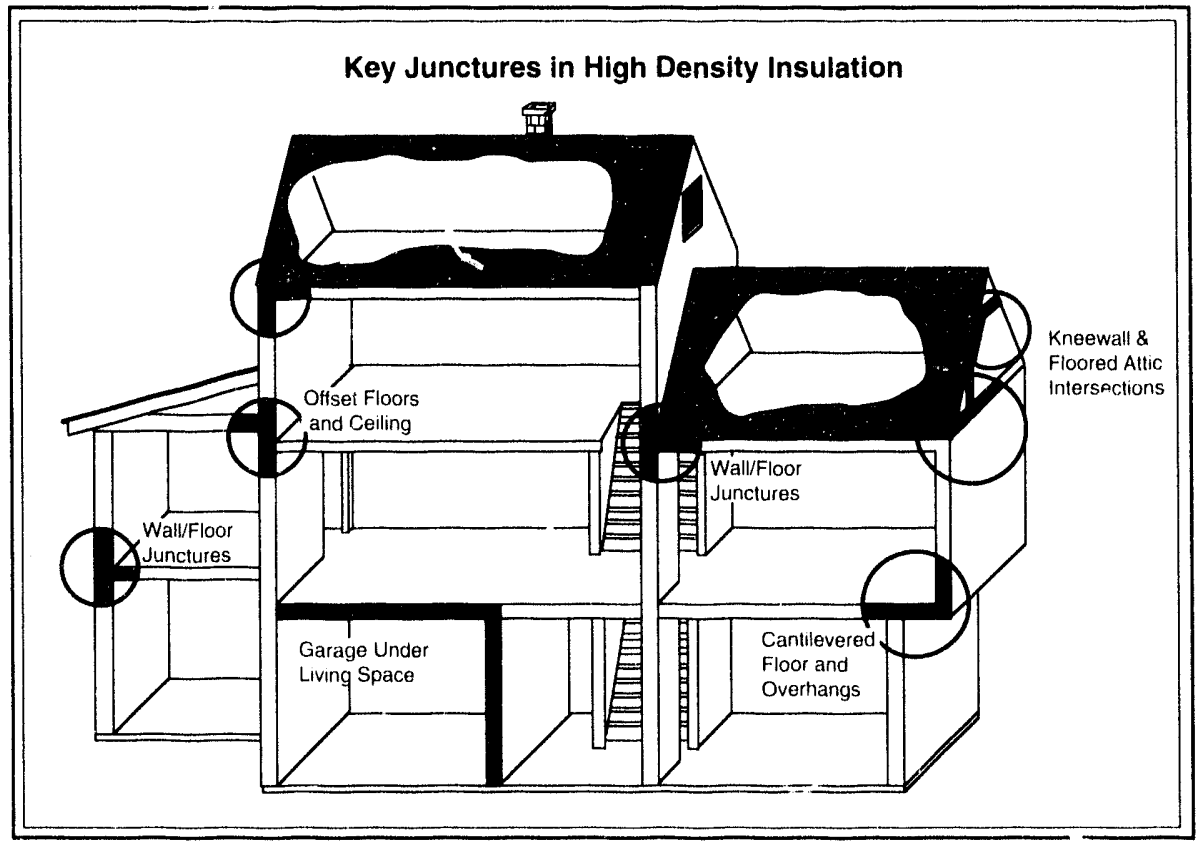




\section{Cost Eff_ctiveness}

Cost effectiveness is a measure of how well a program works. To assess the cost effectiveness of the Weatherization Assistance Program, the market value of energy savings (and in some cases other benefits) was compared to the cost of installing the measures that produced them. Benefits and costs were discounted over the estimated life of the measures. Cost effectiveness was assessed only for single-family and small multifamily dwellings because estimates of program impacts were not available for large multifamily buildings, which comprised only 9 percent of the dwellings weatherized in 1989.

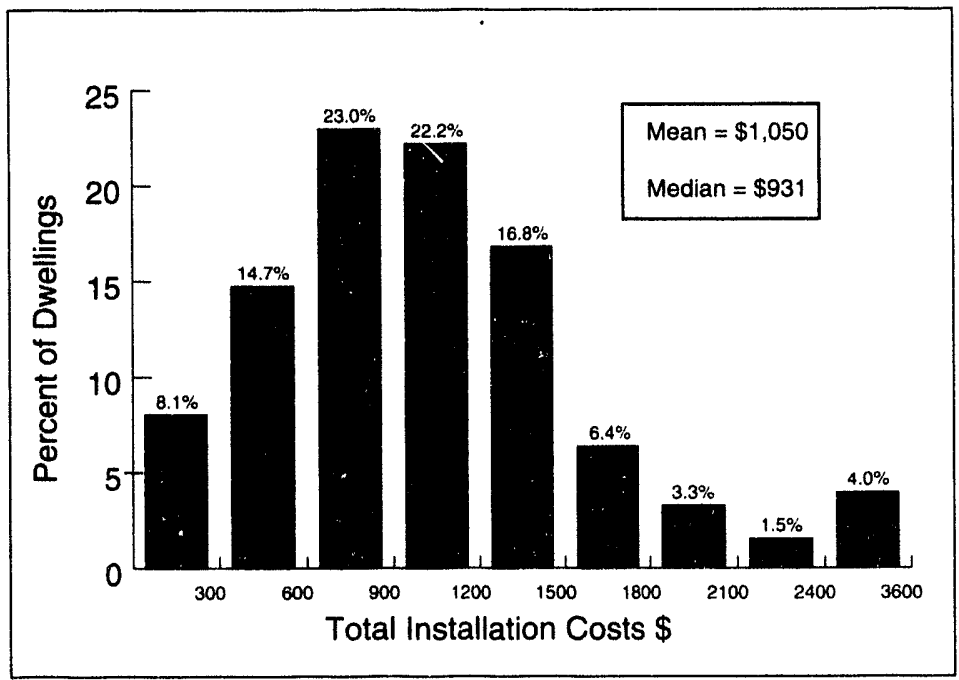

Installation Costs for Single-Family and Small Multifamily Dwellings Weatherized in 1989.

\section{Program Costs}

DOE regulations in 1989 required (subject to certain exceptions) that the average of all costs not exceed $\$ 1,600$ per house and that at least 40 percent of this total be spent on materials that remain in the weatherized houses. ${ }^{4}$ When the weatherization work is supplemented by non-DOE funds, average costs may exceed $\$ 1,600$, and materials costs may represent less than 40 percent of the total.

To provide a picture of costs that is reasonably consistent regardless of the sources of funds used, costs were grouped under two broad categories: (1) installation costs (i.e., labor and materials assignable to particular houses) and (2) overhead and management costs. Overhead and management costs include costs directly related to installation but not readily assignable to particular houses (e.g., vehicles, travel time, and field supervision) and program management (e.g., intake, inspections, and general administration).

Installation costs for single-family and small multifamily dwellings weatherized in 1989 averaged $\$ 1,050$. For not quite half (45 percent) of the dwellings, these costs fell within the $\$ 600$ to $\$ 1,200$ range. The chart shows the range of costs.

Because of variations in record-keeping, it proved difficult to specify overhead and management costs with the same degree of precision as installation costs. After approaching the problem from several perspectives, the evaluators settled on an average cost of $\$ 500$ per single-family and small multifamily dwelling nationwide.

The evaluation examined cost-effectiveness in detail from three perspectives:

- The installation perspective: the only benefit valued was net energy savings and the only costs included were installation expenditures;

- The program perspective: the only benefit valued was net energy savings, and costs included installation, management, and overhead costs; and

- The societal perspective: benefits included both net energy and nonenergy benefits, and costs included installation, management and overhead. 


\section{HEATING SYSTEMS}

From left to right: A boiler technician, a local weatherization official, and an owner celebrate the recent installation of an energyefficient boiler in a large multifamily building in BrookIyn. Owners in New York and some other states provide 25 percent or more of the cost of the work, thus leveraging scarce weatherization funds.

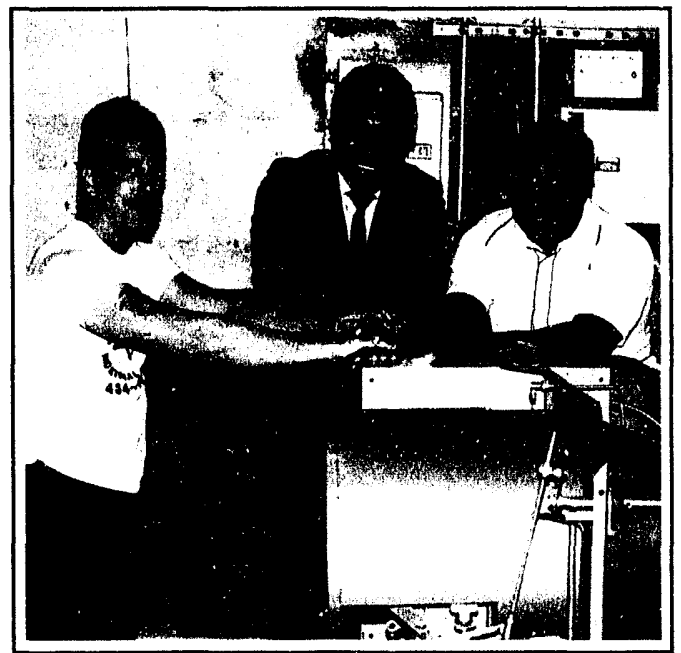

Furnace testing for safety and efficiency has recently become a routine part of many weatherization operations, yet there are still states which pay little attention to heating system work. Others do major work-when needed--ranging from switching to efficient oil burners to boiler replacement.
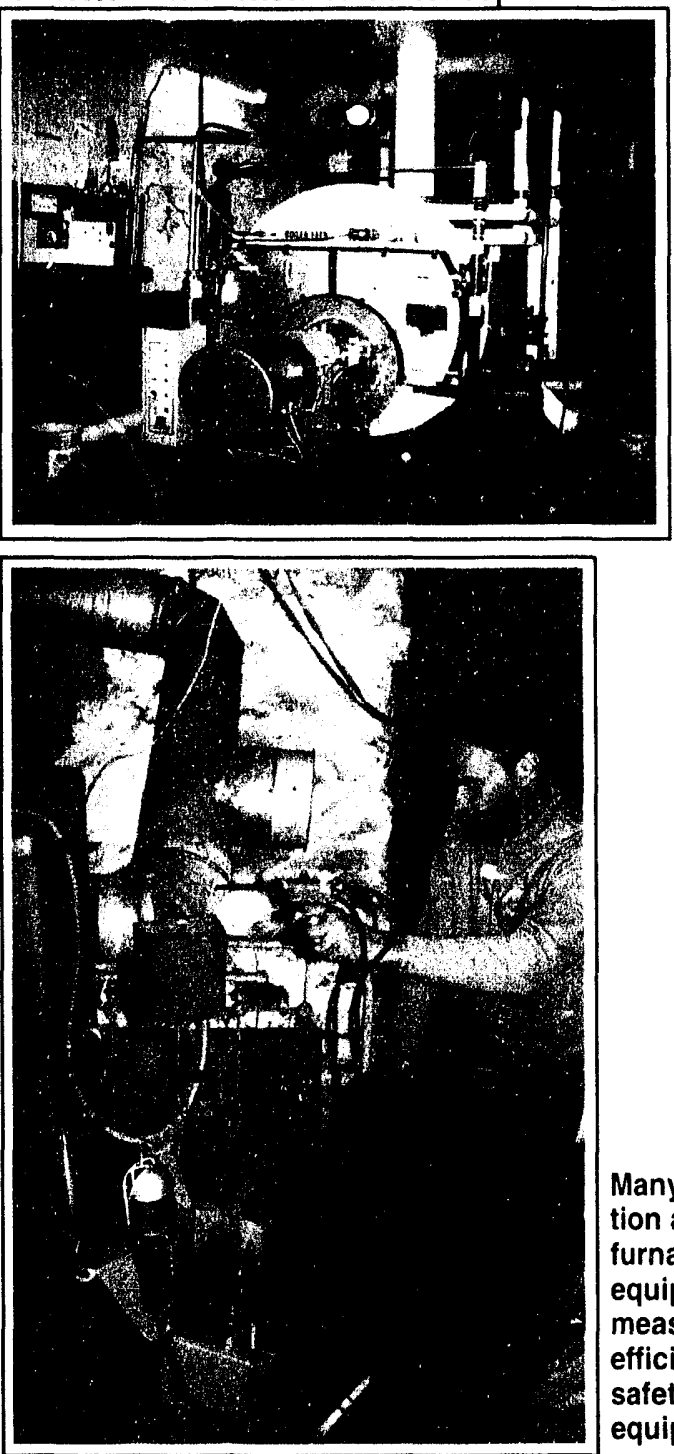

Many weatherization agencies use furnace testing equipment to measure the efficiency and safety of heating equipment.

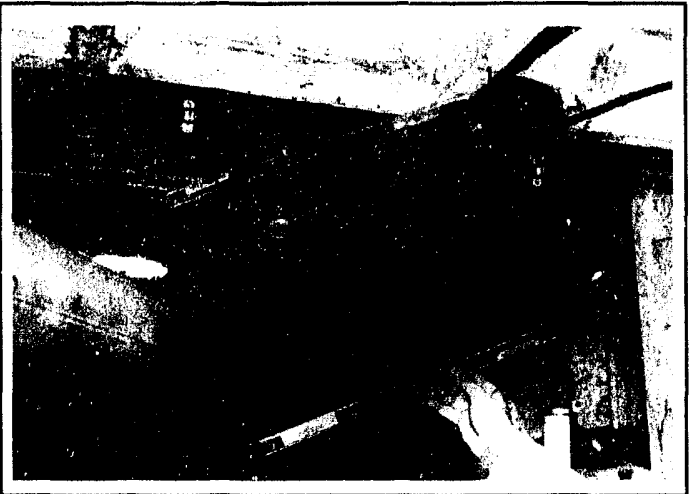

Filthy return air filters, found frequently in the weatherization program, are both unhealthful and inefficient. Cleaning and tuning of furnaces, setting controls for efficiency, replacing filters-and empowering clients to do the job in the future-are routinely accomplished in most weatherization operations. 


\section{National Cost-Effectiveness}

The results of each of the three perspectives used to measure costeffectiveness are described below.

The installation perspective is the traditional approach used to evaluate weatherization programs. Nationally, for gas-heated dwellings, weatherization costs averaged $\$ 1,015$. Average energy savings benefits were calculated to be worth $\$ 1,605$. The resulting benefit/cost ratio, therefore, is 1.58 . For electrically heated dwellings, average expenditures of $\$ 1,025$ yield energy savings henefits of $\$ 1,728$, producing a benefit/cost ratio of 1.69 . For dwellings located in the Northeast heated primarily with fuel oil, average installation costs of $\$ 1,192$ yielded energy saving benefits of $\$ 2,694$, producing a benefit/ cost ratio of 2.26 .

For the 1989 Program as a whole, including all fuel types, the installation benefit/cost ratio is 1.61 .

The program perspective is the most conservative analysis because it includes all classes of costs (i.e., both installation costs and

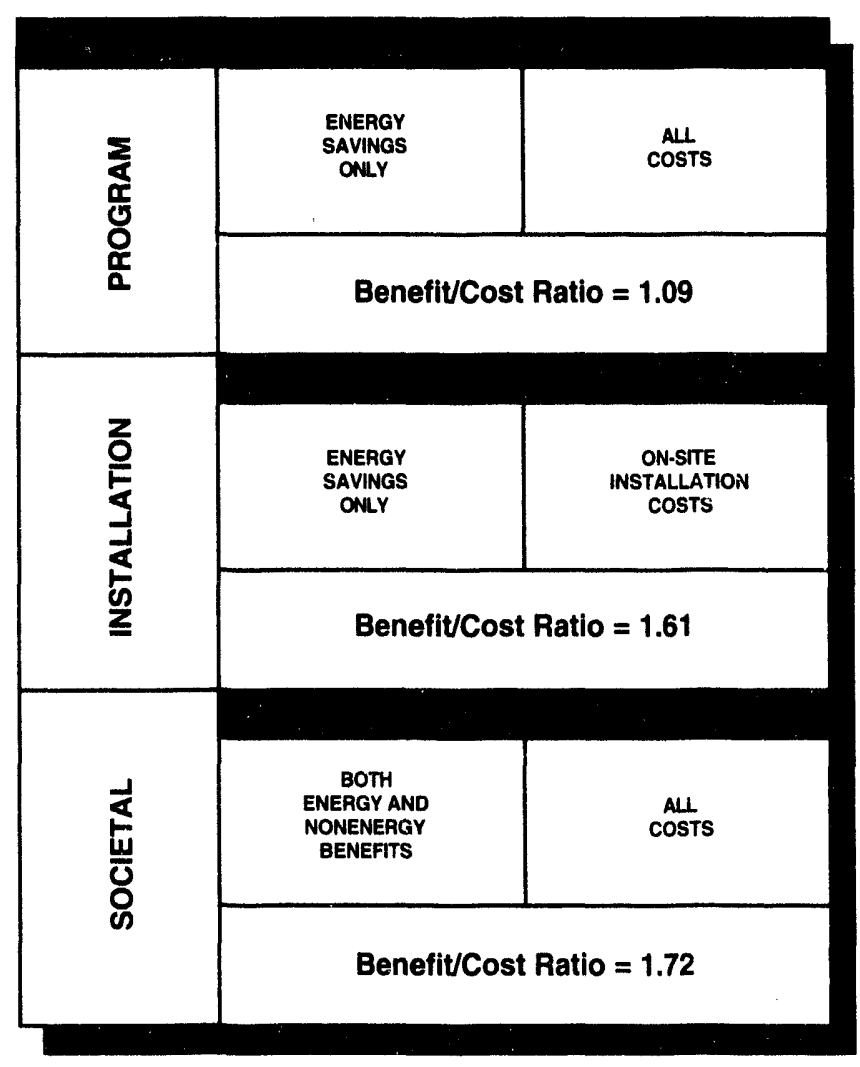
program overhead and management) but only the value of energy savings as a benefit. From this perspective, the national program is still cost-effective. For gas-heated homes, the benefit/cost ratio is 1.06 . For electrically heated homes, the ratio is 1.13 , and for dwellings located in the Northeast heated primarily with fuel oil, the benefit/cost ratio is 1.48 .

For the Program as a whole, including all fuel types, the program benefit/cost ratio is 1.09 .

The societal perspective produces the highest benefit/cost ratios because it includes an estimated value of the nonenergy benefits of weatherization (\$976), which exceeds the overhead and management costs of weatherization $(\$ 500)$. For gas-heated dwellings, the benefit/cost ratio is 1.61 . For electrically heated dwellings, the benefit/cost ratio is 2.33 . For fuel-oil-heated dwellings located in the Northeast, the benefit/cost ratio is 2.01 .

For the Program as a whole, including all fuel types, the societal benefit/cost ratio is 1.72 .

The bottom line is that the Program is a cost-effective government investment. Total costs (including materials, labor, overhead, and management) for all fuel types averaged $\$ 1,550$ per single-family and small multifamily dwelling weatherized in

National Benefit/Cost Ratios fer All Fuel Types for the 1989 Program.
Program Year 1989. The net current value of the energy saved per dwelling is $\$ 1,690$ (in 1989 dollars). This results in a benefit/cost ratio of 1.09 . When conservative values are included for some of the Program's various nonenergy benefits, the benefit/cost ratio increases to 1.72 . 


\section{DISTRIBUTION SYSTEMS}

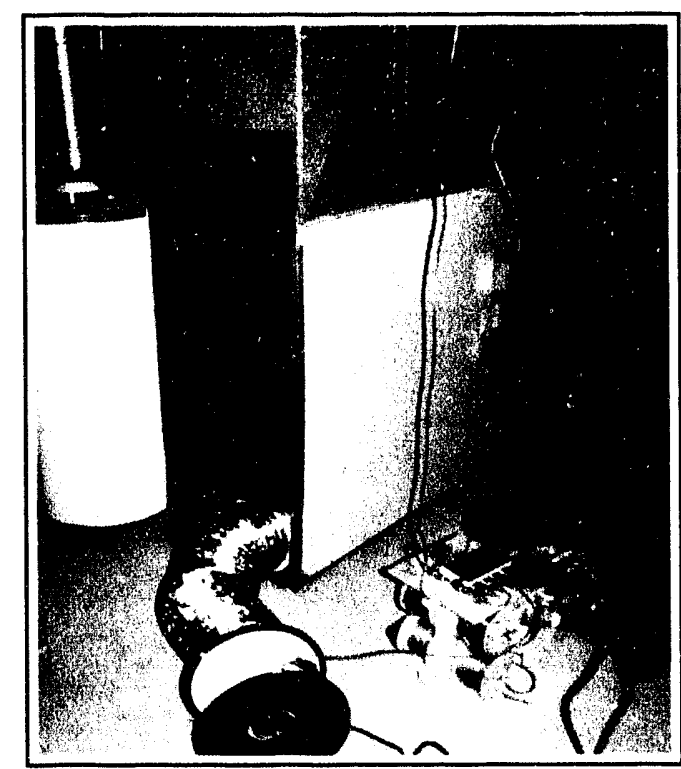

The blower door and pressure-measuring yauges are useful both in quantifying duct

leakage associated with duct work and in revealing the locus of significant leaks.

Protocols for using both blower doors and the distribution system's own fan to quantify

leaks are currently being developed, and several companies have recently developed small calibrated blowers use? $y$ in in leak detection and quality control in duct sealing.

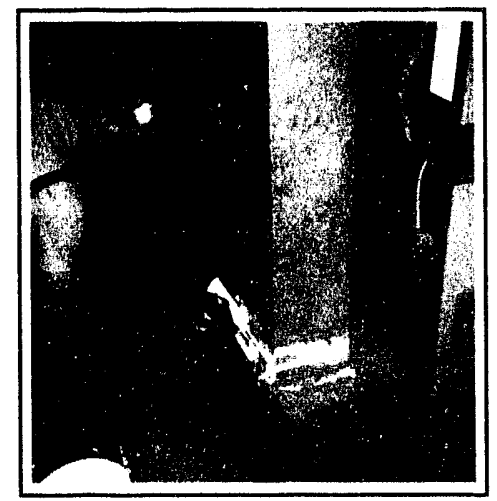

Permanent air sealing of the return air system is accomplished with a fiberglass mesh and special mastic.

This return air duct is the only one in the dwelling for a $100,000 \mathrm{Btu} /$ hour furnace in a Philadelphia row house. Undersized by a factor of $\mathbf{2 0}$ when initially installed, it is now full of dirt. A $\$ 50$ retrofit would save well over $\$ 100$ each heating season.
Recent research has revealed that the distribution systems associated with central heating and air conditioning units are themselves frequently leaky. The combination of loose houses and large holes in return air systems results in inefficiency, uncomfortable drafts, and high energy bills. The combination of tight houses and large holes in return air systems can cause backdrafting of the products of combustion from furnaces and hot water heaters, can dramatically increase the rate at which radon enters the dwellingand can speed all of these undesirable gases through the furnace's heat exchanger directly into the main part of the dwelling.

Duct problems can also negate the benefits of other weatherization work. On the other hand, sealing and balancing duct systems can raise furnace system efficiency, lower overall air infiltration, solve moisture problems, enhance indoor air quality - and save energy.

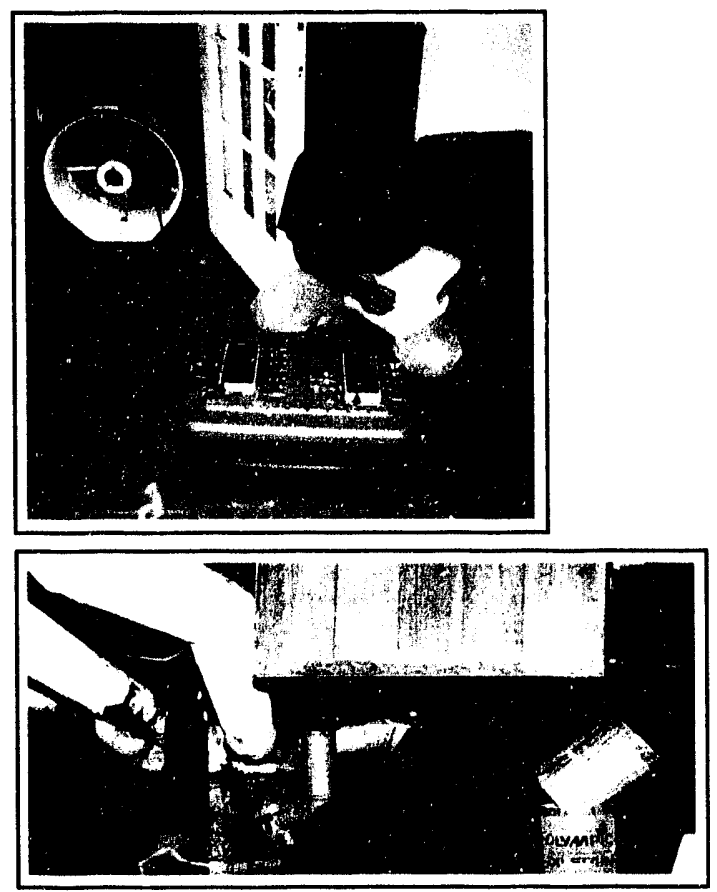

A wooden return system on a gravity furnace is not only leaky but also immediately adjacent to sundry volatile organic compounds. When the furnace is fired, fumes from these compounds can be whisked from the basement into the living area.

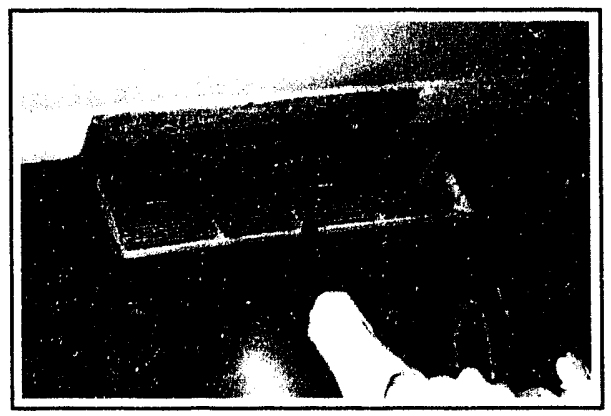

Holes like these in supply ducts can be quite wasteful-yet they can be repaired quickly and cost-effectively. 


\section{Performance by Climate Region}

Performance indicators for the national Program mask a great deal of diversity. This diversity springs from regional differences and associated housing types and needs and from varying practices of weatherization agencies. The following sections present the evaluation results by region. Characteristics of the housing stock and local agencies account for much of the regional variation in weatherization practices and measures installed. These, in turn, provide important background for understanding regional variat:ons in weatherization costs, energy savings, and cost-effectiveness.

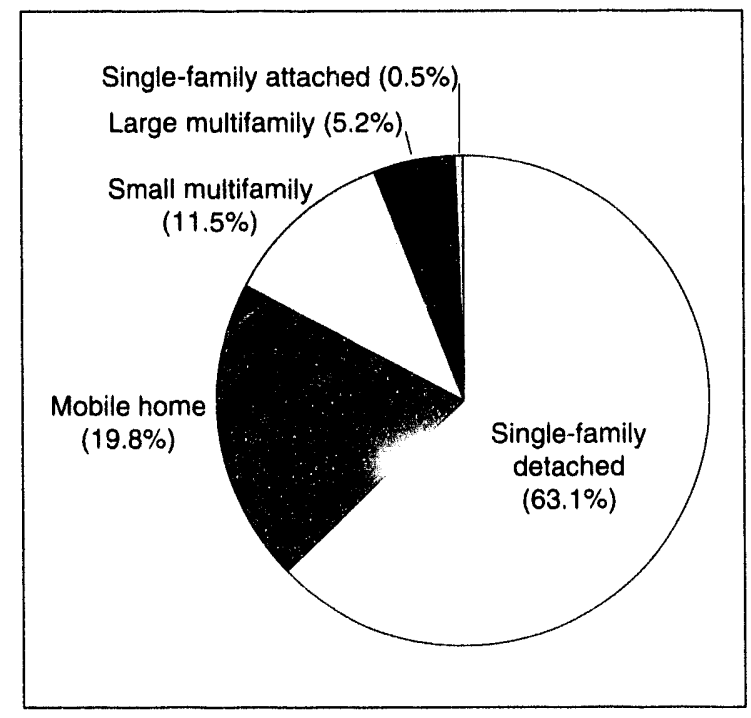

Types of Dwellings Weatherized in 1989 in the Cold Region.

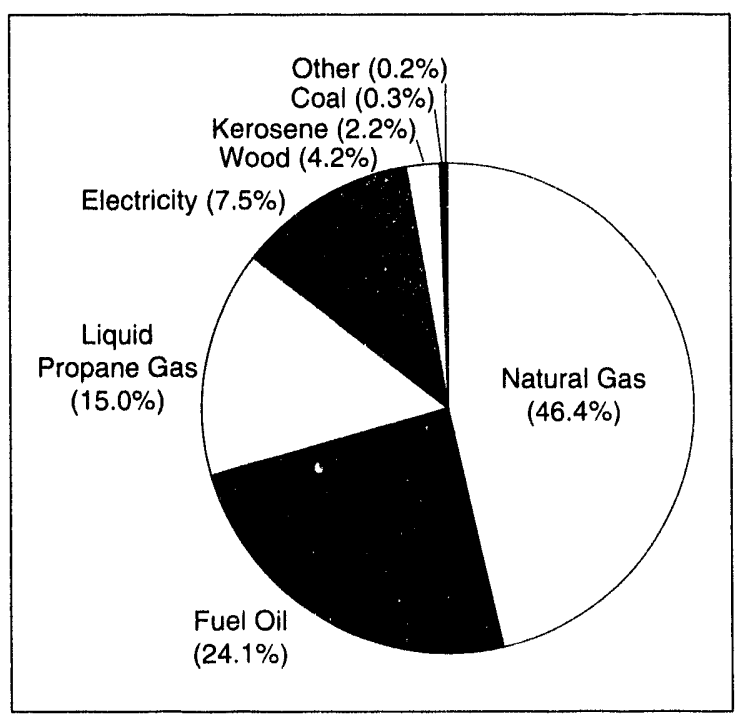

Types of Heating Fuels in Single-Family and Small Multifamily Dwellings Weatherized in 1989 in the Cold Region.
As a whole, the Program is most cost-effective in the cold and moderate climate regions of the country, where programs are concentrated. In the hot region, where agencies are smallest and the low-income housing is most dilapidated, the Program saves less energy per dollar expended.

\section{The Cold Climate Region}

The cold region contains 11 states with an average of 7,444 heating degree days. In 1989, approximately 150 local agencies in this region weatherized more than 40,000 dwellings ( 18 percent of the total weatherized population).

Benefit/cost ratios are greater in this region than in any other region, ranging from 1.3 to 2.9 depending upon the "perspective." This region also achieves the highest savings of any region, based on the SingleFamily Study. For natural gas consumption, the first-year net savings of $235 \mathrm{ccf}$ represent a 25 percent reduction in the gas used for space heating and an 18 percent reduction in total gas usage. Net electricity savings total $2,686 \mathrm{kWh}$ for the first year, which is a 42 percent reduction in electricity use for heating and a 14 percent reduction in total electricity usage. Total costs average $\$ 1,576$ per household, higher than the national average.

The majority of weatherized homes in the cold region are singlefamily detached (63 percent). Findings from the Single-Family Study show that this region has the oldest housing stock (averaging 45 years) and weatherizes dwellings that are on average larger than the other two regions $(1,181$ square feet $)$. The primary heating fuel, as with all regions, is natural gas. This region, however, has a significantly higher portion of the population using fuel oil. A central heating system was found in 83 percent of the dwellings, the largest proportion of any region, and supplemental heating fuels are less common ( 24 percent of the weatherized single-family population). Two-thirds of these dwellings are owner-occupied, and they have the largest average number of occupants of any region.

The cold region uses the most rigorous methods for both client and weatherization measures selection. Integrated audits for measures selection are used over three times more frequently than the national average. The use of advanced diagnostic techniques is higher than in any other region. The Single-Family Study shows that blower door tests are performed almost twice as frequently as the national average. The cold climate zone has high installation rates for insulation, water heating, and space heating measures. In contrast, the cold region has relatively low installation rates for structuril measures and windows and doors. 


\section{DOMESTIC HOT WATER}

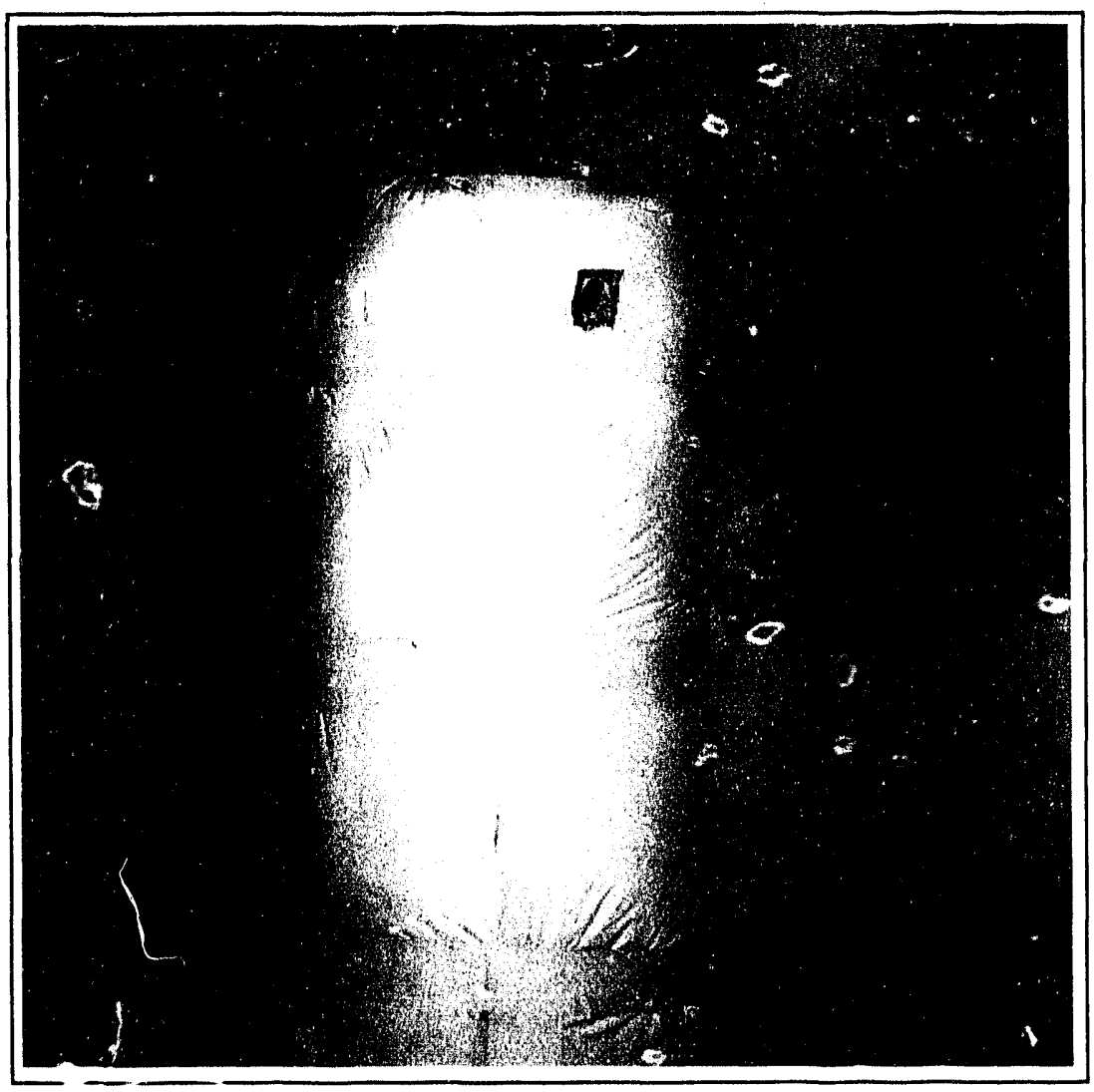

Conserving energy used to heat water is usually a cost-effective undertaking. Stopping leaks with minor plumbing repairs can result in substantial savings, as can installing low-flow devices like shower heads and faucet aerators. Most weatherization agencies report that the best results come from combining client education with good-quality shower heads. Similarily, the installation of tank insulation by weatherization agencies is frequently accompanied by turning down the thermostat on the water heater, an action that is often taken in conjunction with client education to promote sustained energy savings. Many agencies also install pipe insulation a few feet on the cold water inlet side (to prevent thermosiphoning during the standby cycle) and 10 feet or more on the hot water side. 


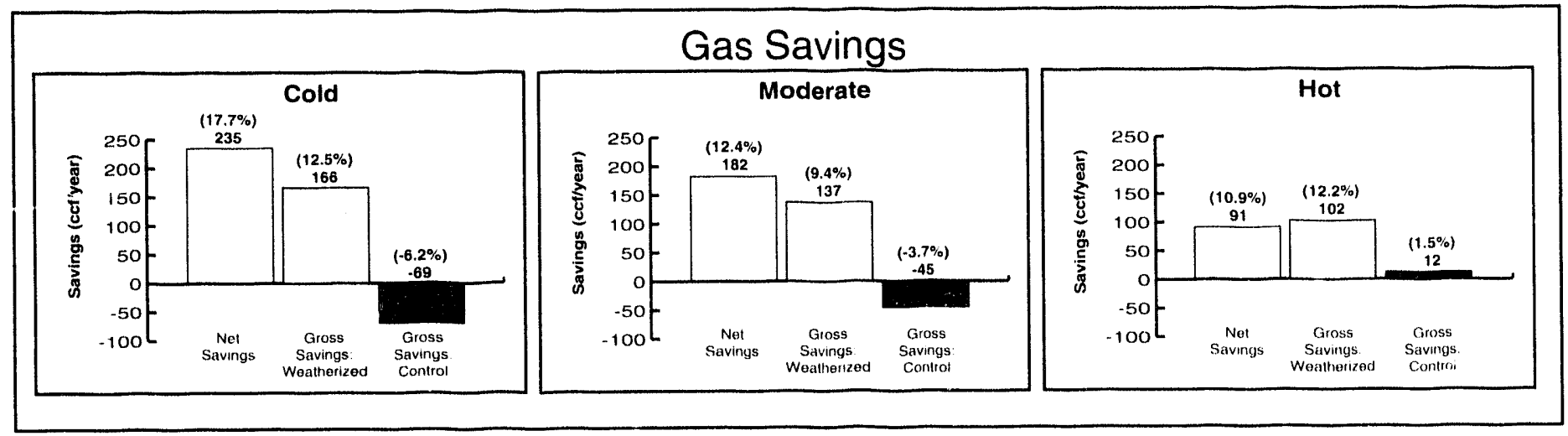

Gas Savings by Climate Region.

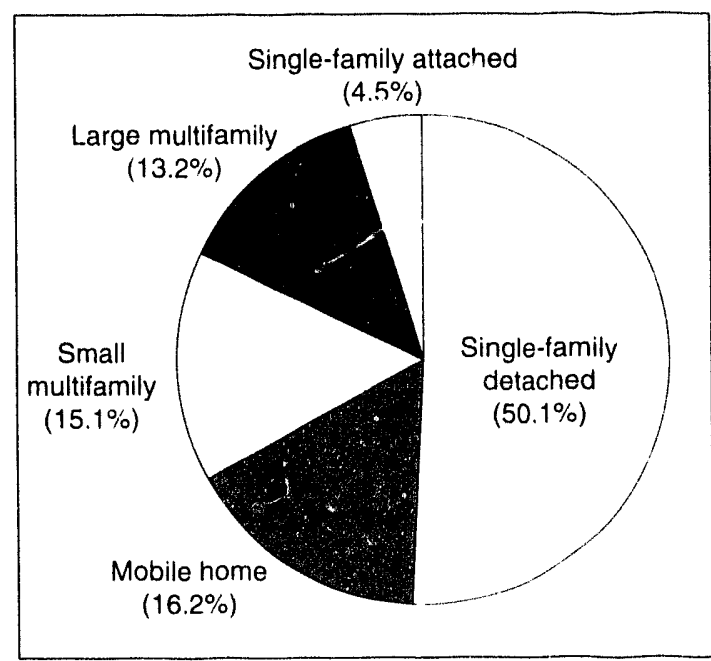

Types of Dwellings Weatherized in 1989 in the Moderate Region.

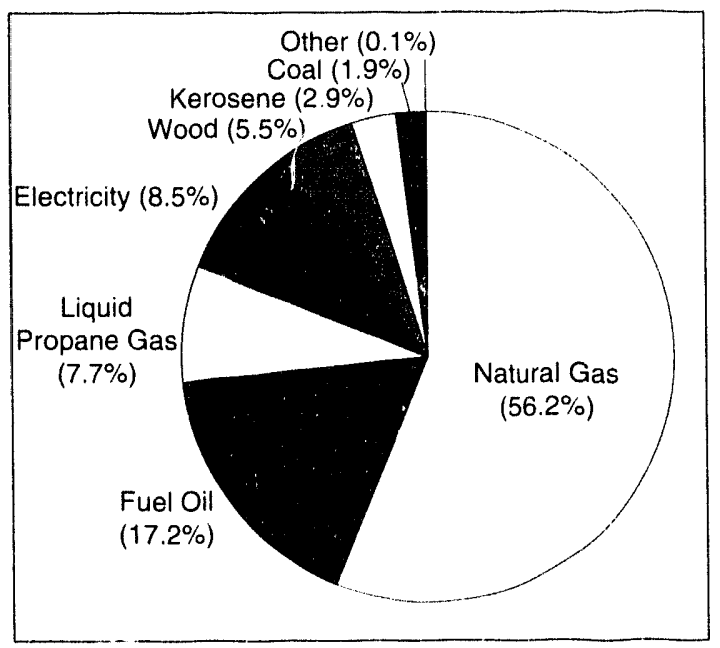

Types of Heating Fuels in Single-Family and Small Multifamily Dwellings Weatherized in 1989 in the Moderate Region.

\section{The Moderate Climate Region}

The moderate region consists of Washington, D.C., and 24 states, including the northern half of California. The region has an average of 5,906 heating degree days. In 1989, this region contained nearly 570 local agencies that weatherized more tha. 140,000 dwellings (64 percent of the total weatherized population ).

Benefit/cost ratios are substantial in the moderate region, ranging from 1.2 to 2.7 depending upon the "perspective." This region also achieves higher than average savings, based on the Single-Family Study. For natural gas consumption, the first year net savings of 182 ccf represents an 18 percent reduction in gas used for heating and a 12 percent reduction in total gas usage. Net electricity savings total $2,479 \mathrm{kWh}$ for the first year, which is a 44 percent reduction in electricity use for heating and a 15 percent reduction in total electricity use. Total costs average $\$ 1,580$ per household, essentially the same as the coid climate region investment level.

Just over half of the weatherized homes in the moderate region are singlefamily detached dwellings. This climate zone also contains a ost 88 percent of all large multifamily dwellings weatherized. Findings from the SingleFamily Study show that this region has dwellings that are older than the national average (44 years on average for the region). The use of natural gas is predominant in this region, with more than 56 percent of the weatherized dwellings (in the Single-Family Study) using this type of fuel. This region contains the smallest population of owner-occupied dwellings ( 59 percent of the single-family and small multifamily dwellings).

In the moderate region, only 15 percent of the clients were selected on the basis of estimated energy use or savings, as compared to 4.3 percent in the cold region. Similarly, integrated audits were used in only 5 percent of the dwellings, compared to 28 percent in the cold region. However, this region excelled in the use of heating efficiency tests as a diagnostic tool and later for quality control. In the moderate region, all of the major types of weatherization measures were installed at higher than national rates. 


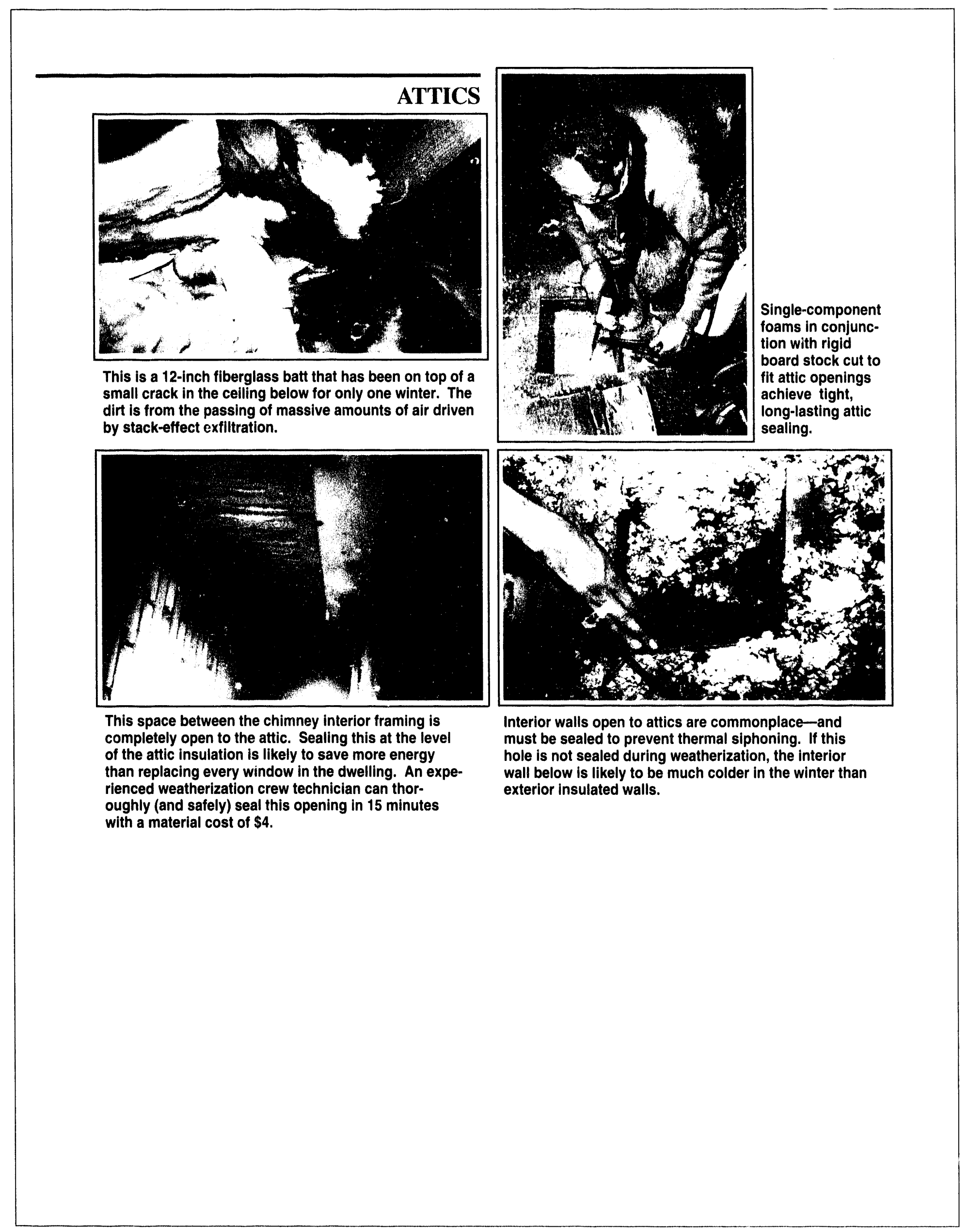




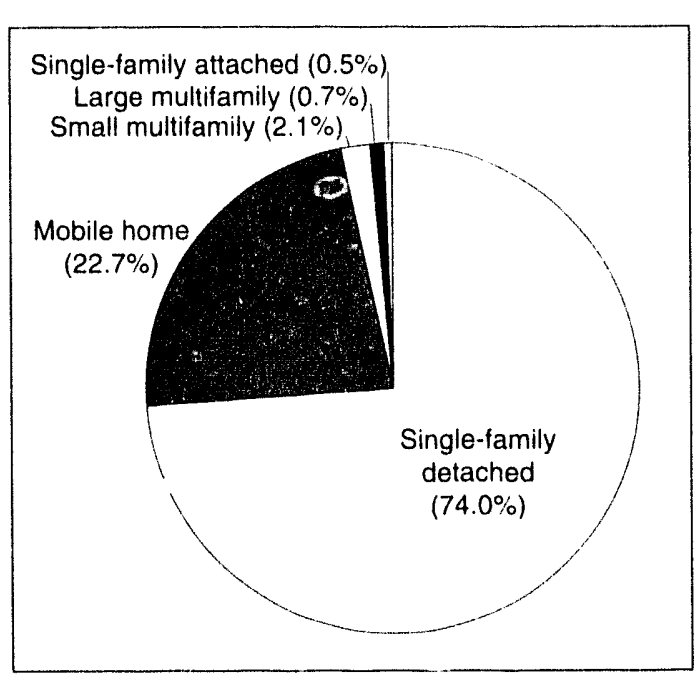

Types of Dwellings Weatherized in 1989 in the Hot Region.

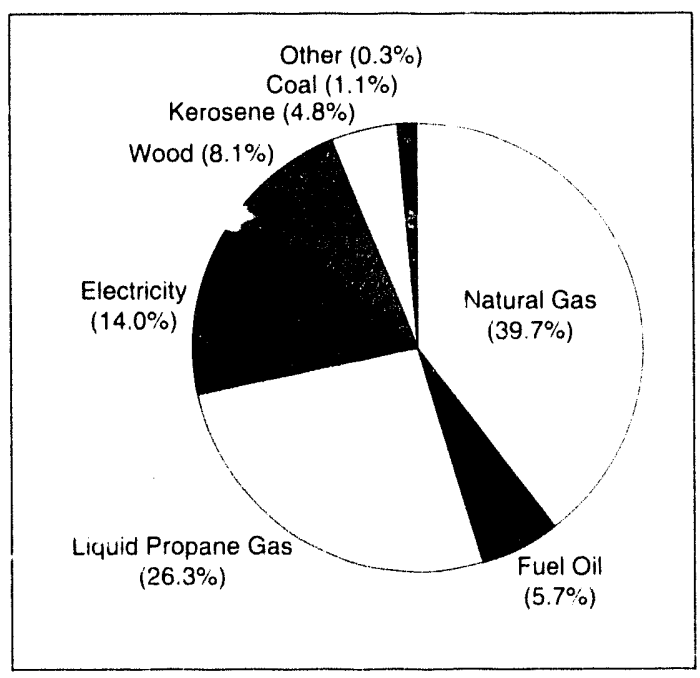

Types of Heating Fuels in Single-Family and Small Multifamily Dwellings Weatherized in 1989 in the Hot Region.

\section{The Hot Climate Regicn}

The hot climate region consists of 14 states, including the southern half of California, and has an average of 2,527 heating degree days. In 1989, this region contained nearly 380 local agencies which served 40,000 dwellings (18 percent of the total weatherized population).

Benefit/cost ratios for the hot climate region range from 0.4 to 1.6 depending on the "perspective." This region saves less than the national average, based on the Single-Family Study. For gas-heated homes, the first year net savings of 91 ccf represents a reduction of 15 percent of total gas used for heating and an 11 reduction in total gas usage. Net electricity savings total $595 \mathrm{kWh}$ the first year, which is a 16 percent reduction in the electricity use for heating, or a 5 percent reduction in total electricity use. Total costs average was $\$ 1,469$ per household, the lowest in the nation.

Nearly three-quarters of the weatherized homes in the hot region are single-family detached homes. This region also has the largest population of mobile homes ( 23 percent of weatherized dwellings). Findings from the Single-Family Study show that this region has by far the youngest and smallest dwellings (averaging 33 years and 987 square feet, respectively). Liquid propane gas is used as a primary heating fuel approximately twice as often as the national weighted average, and central heating systems are present in only one-quarter of the homes weatherized in 1989. The hot region also has the largest proportion of elderly occupants (62 percent higher than the national average) and handicapped occupants (67 percent higher than the national average).

In this region, measures are usually selected from priority lists rather than through the use of an energy audit, and sophisticated diagne stics are rarely used. Space-heating measures were installed in only 2 percent of the dwellings in this region, according to the Single-Family Study. Insulation and air leakage control measures were also installed less frequently than the national average. In contrast, the hot region installed more window and door measures and spent 28 percent more than the national average on structural measures, reflecting the more dilapidated condition of lowincome housing in this region.

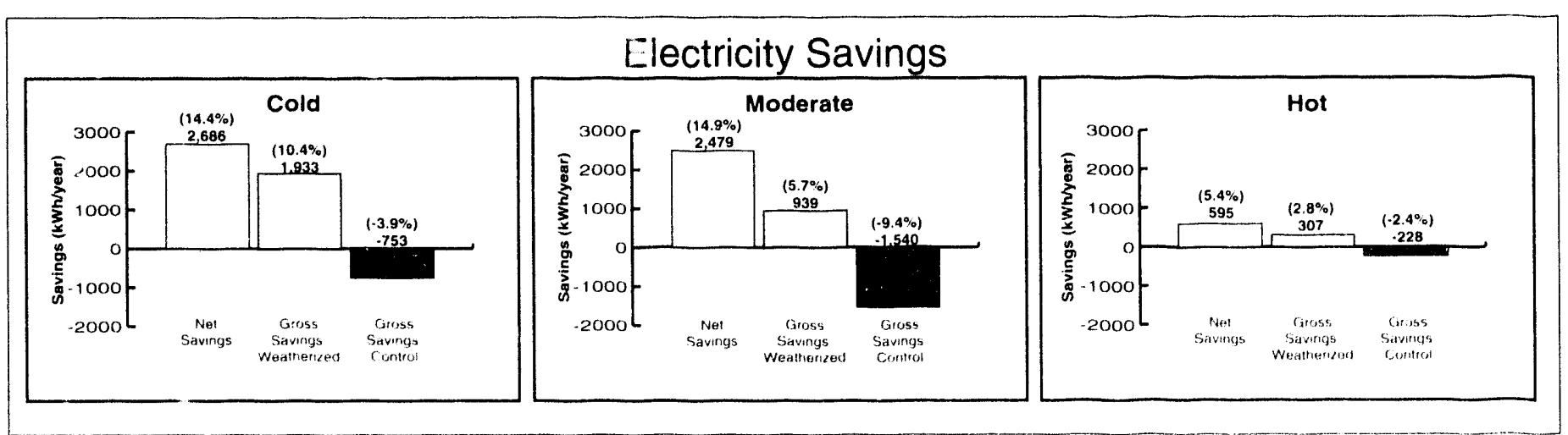

Electricity Savings by Climate Region. 


\section{MOBILE HOME MEASURES}

Many mobile homes have inconspicious air leakage paths thai can be clearly identified with blower doors, yet at the time of the Single-Family Study, few agencies in the hot region used blower doors. Successful weatherization work focuses on closing leaks at the bottom of the conditioned envelope, especially around the duct system. A recent Indiana study showed 32 percent savings in mobile homes resulted from blower-door guided infiltration reduction and blowing cellulose insulation in the belly board.

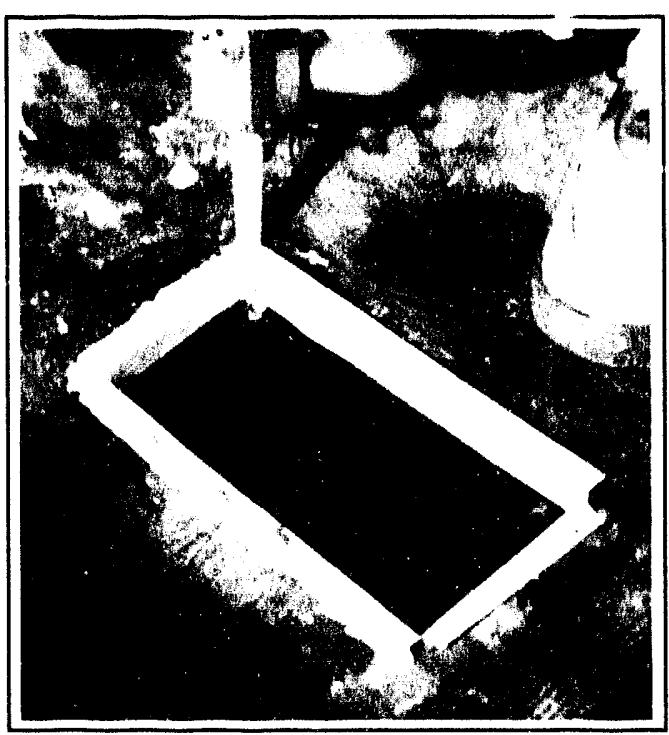

The interface between the riser in a supply duct and the floor of a moblle home is frequently found to be a source of air leaks, both when the furnace fan is on and when it is not. Here a technician in Indiana uses a technique his agency developed to achieve a tight, lifelong seal.

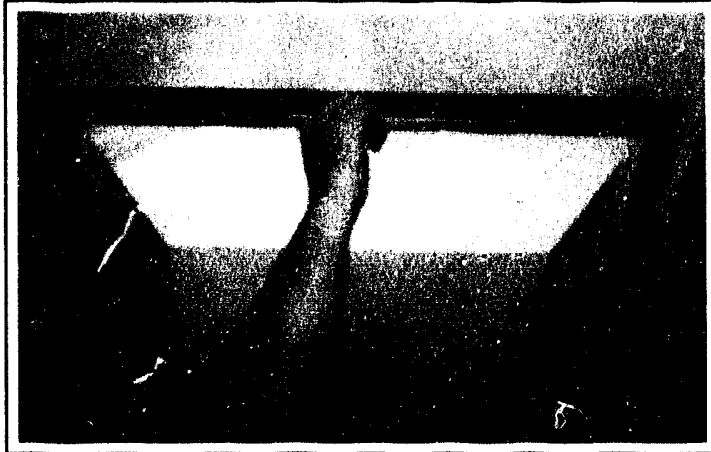

Sealing the opening to the evaporative cooler during winter months is routinely accomplished by weatherization technicians in Arizona, who find this a very cost-effective weatherization tactic with both mobile homes and site-built structures. Solar screens also result in significant savings in this semidesert climate.

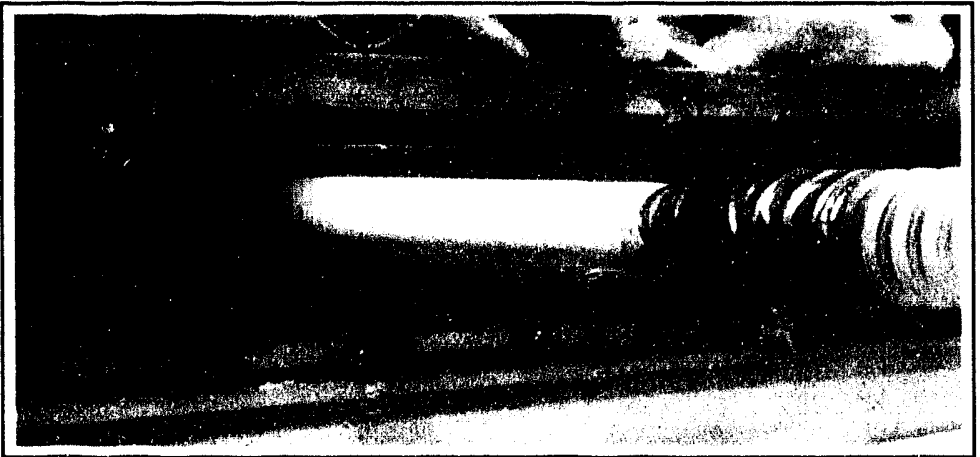

A 30 -foot-long plastic pipe is used to blow insulation between the belly board and the floor of a mobile home. 


\section{FOUNDATIONS FOR CHANGE}

The fundamental purpose of the National Weatherization Evaluation is to analyze the performance to date and identify promising opportunities for the future. Knowing which measures tend to produce good savings-and which don' $t$-is critical in providing useful feedback to weatherization practitioners.
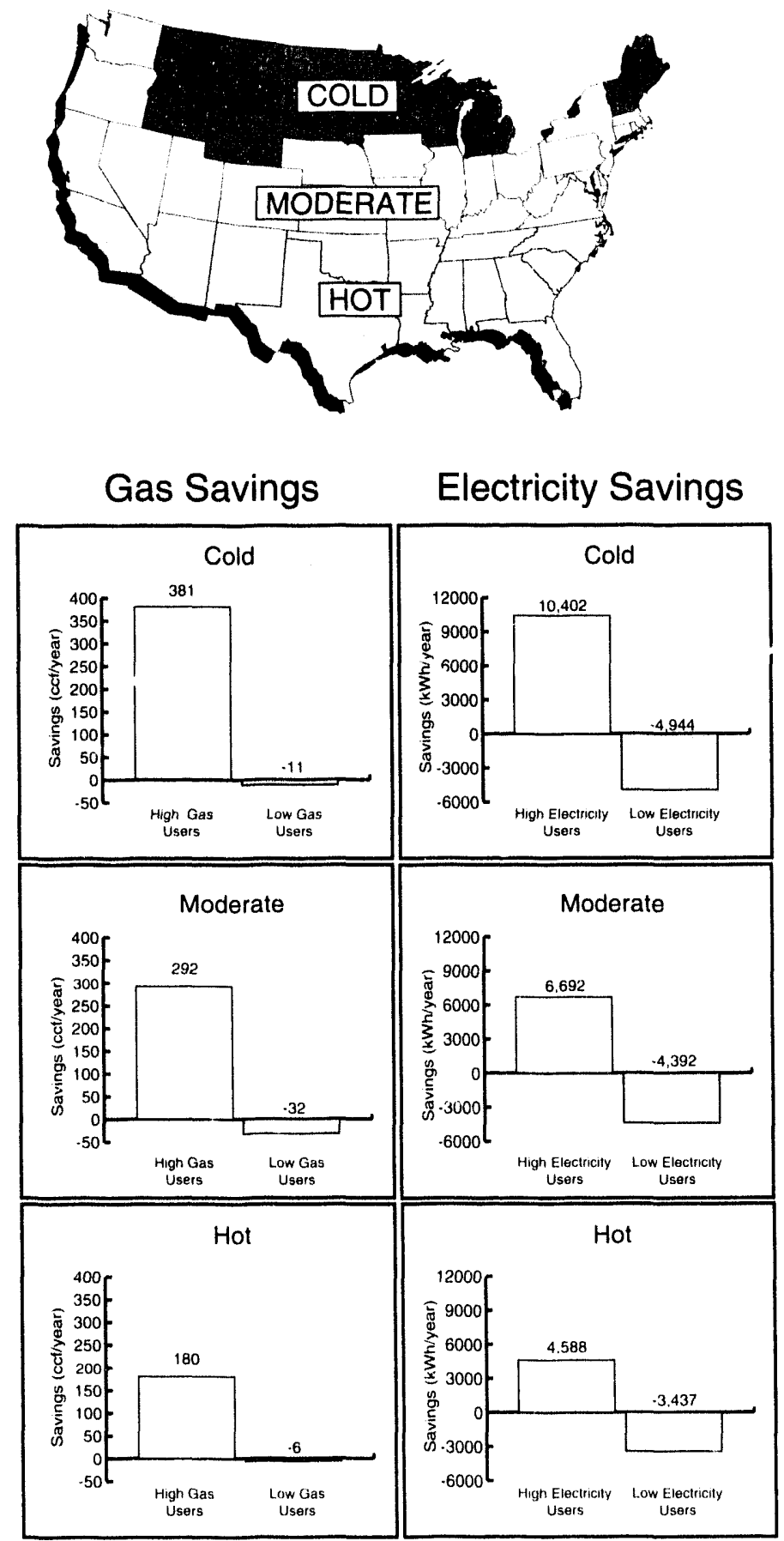

Energy Savings Is Greatest in Homes That Use the Most Energy.

\section{A. Savings Associated with Specific Pro- gram Practices}

The study found that the following practices are associated with higher-than-average savings:

- Weatherizing high energy users. Within each climate region, weatherizing high energy users is associated with high energy savings. High energy use usually points to specific weaknesses in the dwelling's envelope or heating system. Solving such problems usually produces highly cost-effective savings. This is illustrated by the figure which shows dramatic differences between savings achieved by the weatherization jobs accomplished on the highest quartile of gas and electricity users versus the lowest quartile.

- Using an integrated audit of the heating system and envelope. Integrated audits help pinpoint problems and guide weatherization work towards what makes a difference-and away from what doesn't. They consider both envelope and heating and cooling system needs, and provide savings-to-investment ratios for individual measures. Although integrated audits were just emerging in 1989, several of the high-performing agencies identified in the Single-Family Study used them.

- Curing distribution system problems. Air leakage from distribution systems can cause serious health and safety problems, as well as affect energy consumption. Curing them is correlated with higher-than-normal savings.

- Replacing furnaces. This measure is not only positively correlated with higher-than-average savings, but also frequently solves safety and health problems. Since this is usually a high-cost measure, its cost- effectiveness-considered as only an energy conservation measure-is not always high. On the other hand, it often is a vital health and safety measure, since removing a furnace with a broken heat exchanger can improve indoor air quality and save lives.

- Installing attic insulation. This evaluation clearly showed that the installation of insulation in attics never before insulated is particularly cost-effective. 


\section{ADVANCED ENERGY AUDITS}

Advanced energy audits consider both elivelope and heating and cooling system needs, and produce estimated energy savings, savings-to-investment ratios, and a list of the quantities of materials necessary to complete weatherization.

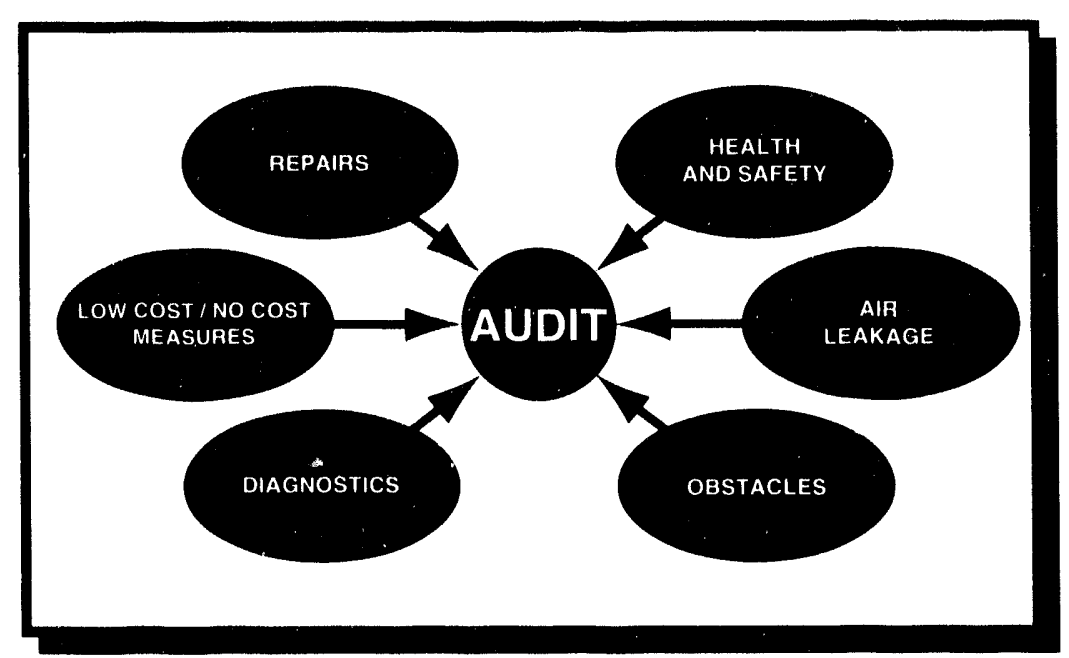

Advanced energy audits can use a variety of data provided by the auditor and by diagnostic measurements (air leakage and equipment efficiencies).
The National Energy AudiT (NEAT) is a sophisticated computer-based audit developed specifically for DOE's Weatherization Assistance Program. NEAT uses a variety of data (on the building and its heating and cooling systems) to produce a prioritized list of cost-effective measures, customized for an individual house. It is advanced, yet user friendly.

This audit is one option for states. Some states have developed comparable audits tailored to their local needs.

\section{SIMPLIFIED OPERATION DIAGRAM OF NEAT}

At the "start," users can:

1. enter building data,

2. customize setup of NEAT, and

3. recall previous building data.

At the "end," users have the option of entering and adjusting results with billing data.

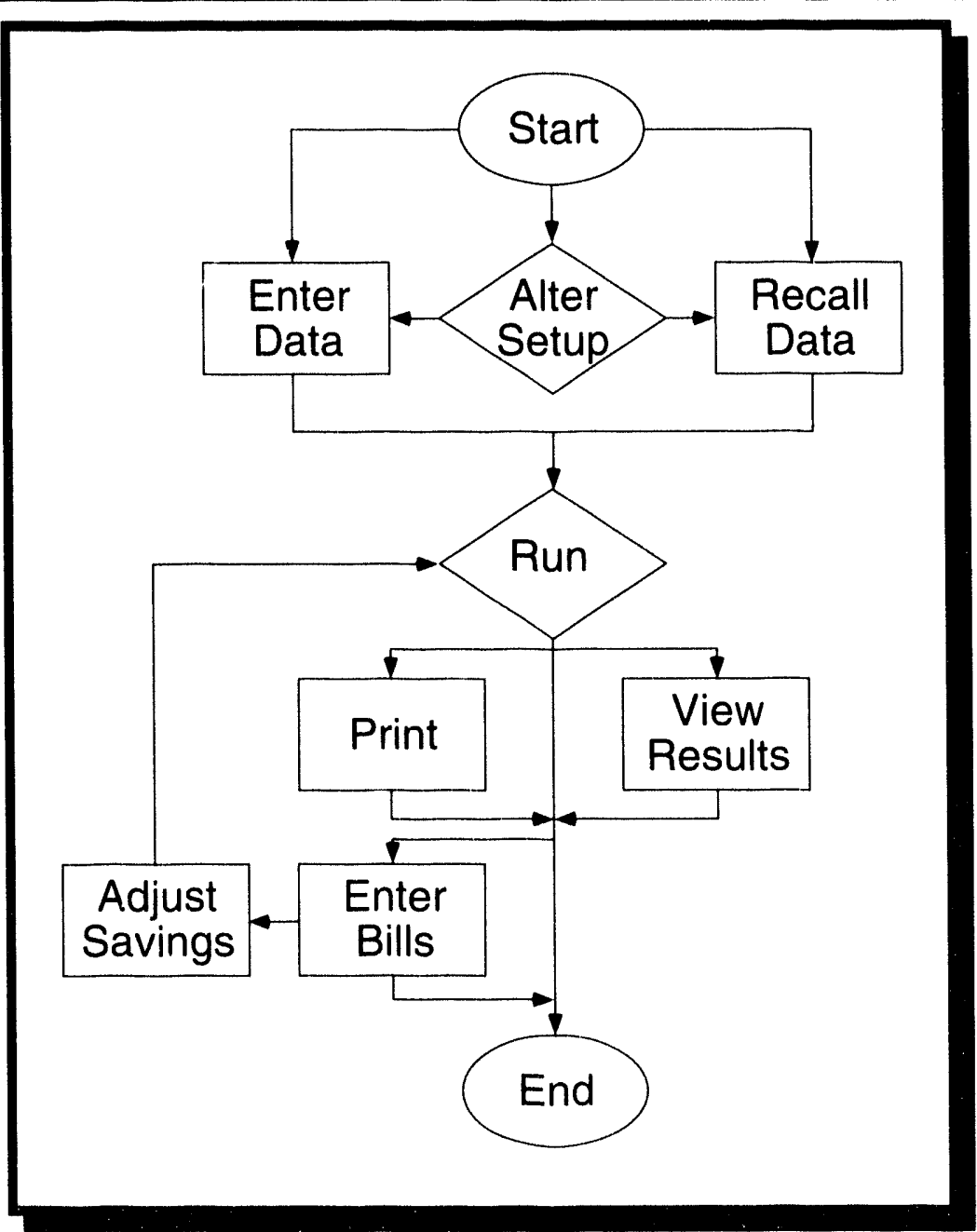


- Installing wall insulation. During the time of the evaluation, only a few agencies had begun using the high-density installation technique (which accomplishes air sealing and insulation with a single operation). However, weatherization jobs that included high-density wall insulation showed even greater savings than those that used the older technique.

- Installing floor insulation. The presence of this weatherization measure was also positively correlated with greater-than-average overall savings. It is especially effective when the floors insulated are over vented crawl spaces.

- Installing water heater measures. These measures include tank and pipe insulation as well as turning down thermostats. The result is a diminution of base-load consumption of natural gas measurable through analysis of billing data.

Investments in storm windows were not generally associated with measurable energy savings. The payoff expected from another measure-blowerdoor-assisted air sealing - also was not discernible in the Single-Family Study. This finding is attributed to the fact that blower doors were just being introduced into local agency procedures in 1989, when only 18 percent of completed dwellings received blower-door-assisted sealing. Today, agencies offer training in their use. In fact, low-income weatherization agencies have become leaders in the application of blower doors and are generally convinced they save energy.

\section{B. Promising Management Practices}

A handful of other practices employed by many weatherization agencies clearly make sense, but their impact could not be quantified through this evaluation. These include client education and resource leveraging. Some agencies are very active in providing client education and report good success in forming partnerships in which recipients of weatherization services participate in a number of concrete conservation activities in their homes.

Leveraging from utilities to accomplish the ends of demand-side management on the one hand and cost-saving conservation services for low-income families on the other is becoming an increasingly important opportunity for enhancing weatherization. Utility partnerships are emerging across the country. Some agencies, for instance, provide electricity conservation services in conjunction with weatherization. These routinely involve removing inefficient incandescent lighting fixtures and replacing them with compact fluorescent lighting, and sometimes replacing inefficient refrigerators with efficient ones. Other utility partnerships have enabled capital-intensive investments such as energy-efficient replacement furnaces that might otherwise not be possible.

Still problematic for many local agencies is the extremely poor condition of many dwellings. The Program will be stronger when adequate housing rehabilitation funding allows local agencies to provide needed repairs and devote a larger share of their DOE funds to energy-efficiency improvements. 


\section{TARGETING SAVINGS POTENTIAL}

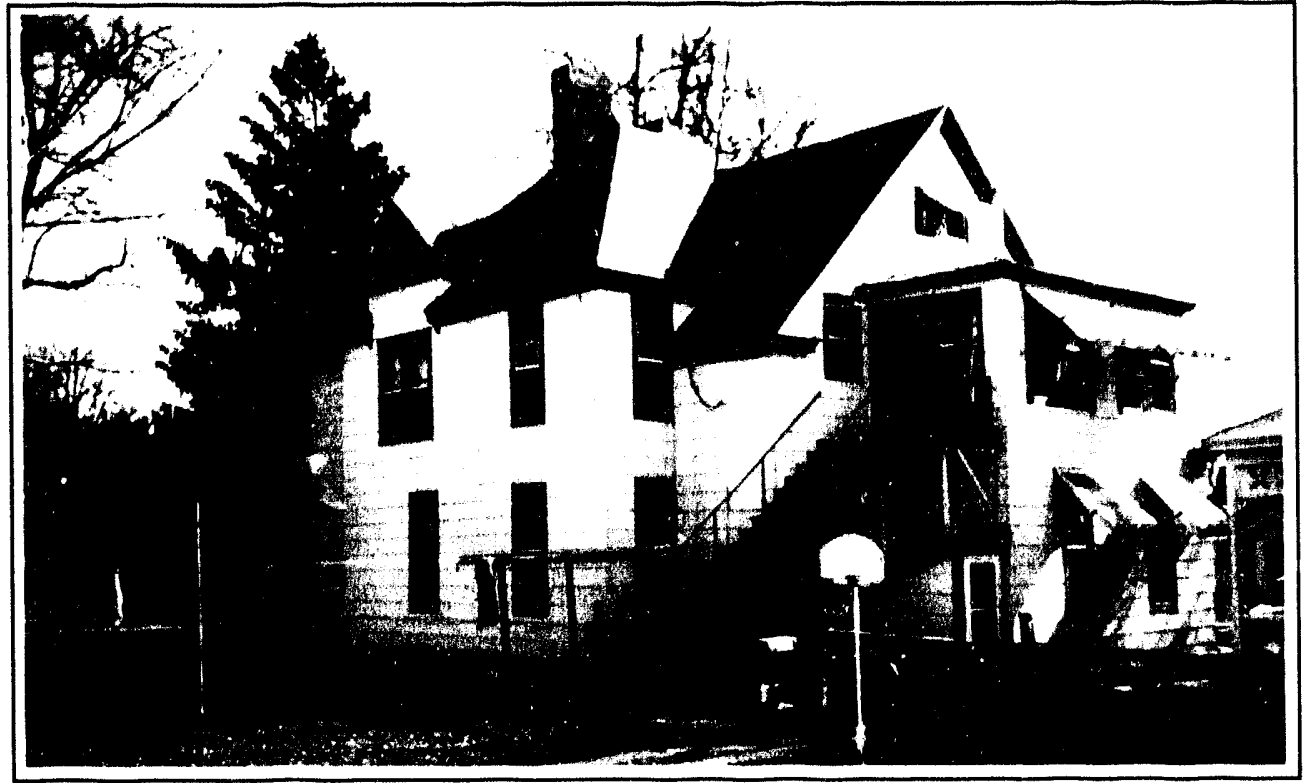

This 90 -year-old home in Nebraska has more than 4,000 square feet of heated living space and 43 windows for its 10 occupants (eight children and two parents). Although the home had 43 storm windows prior to weatherization, the heating system was inefficient, the attic insulation was insufficient, and no floor or wall insulation was present. Before weatherization, the house consumed 4,800 ccf of gas each year, resulting in annual heating bills of approximately $\$ 2,500$, creating a significant energy burden for this household.

The local weatherization agency spent $\$ 2.250$ in direct materials and labor from a variety of funding sources to weatherize this home. Most of its effort was dedicated to adding insulation to the attic, sidewalls, kneewalls, collar beams, and floor. In addition, the water heater and water pipes were insulated; air leakages were sealed; the space heating system was cleaned, tuned, and repaired; and several doors and windows were fixed.

These weatherization measures resulted in a $25 \%$ reduction in the household's home heating bills, and created a much more comfortable living environment. The occupants described their home as "very drafty" prior to weatherization and "not at all drafty" afterwards.

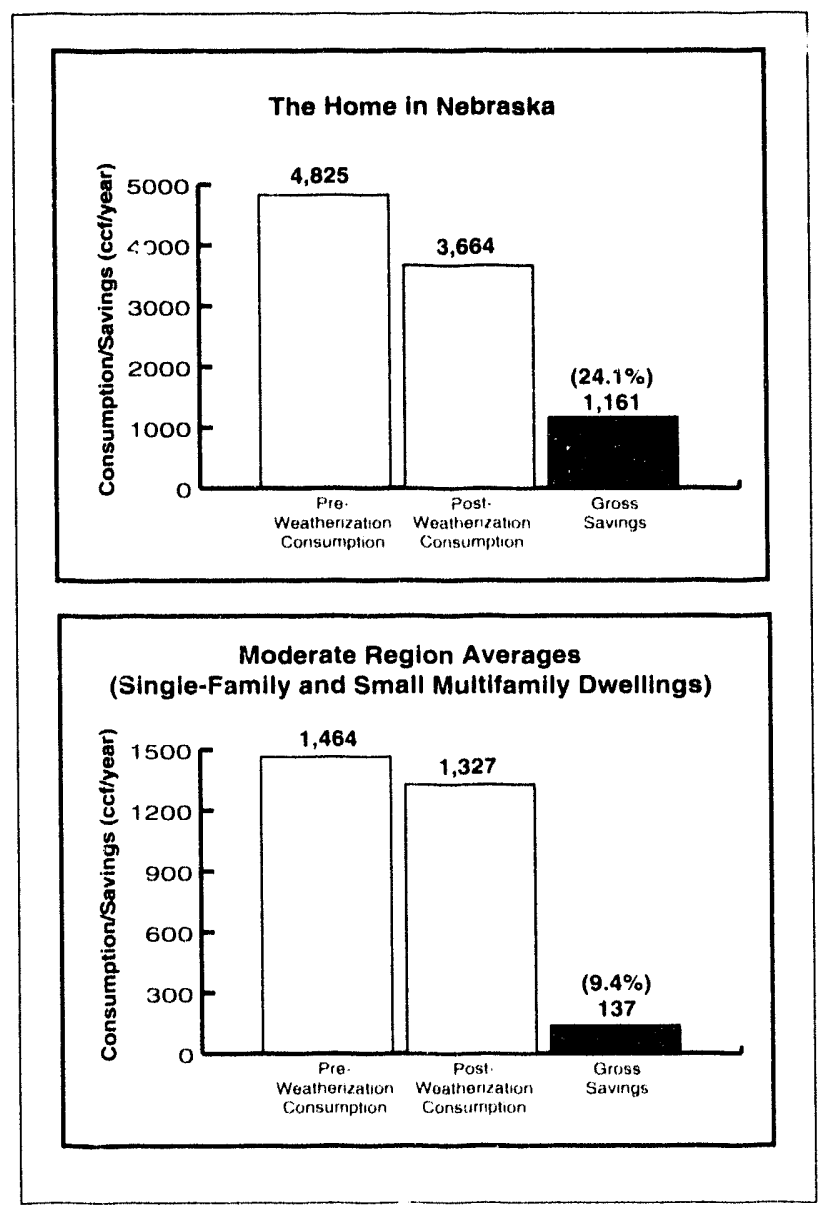




\section{THE FUTURE OF WEATHERIZATION: THE NEXT STEPS}

The various reports produced to date by the National Weatherization Evaluation present a comprehensive profile of weatherization procedures and measures that characterize high-performing agencies and high-saving dwellings. The following recommendations result from these interim findings and describe a series of next steps to enhance the Weatherization Program beyond its already strong foundation.

\section{A. Service Delivery Procedures}

- Enhance the existing high quality of the weatherization work force through increased training and professional development. High-performing agencies are characterized by experienced and well-trained employees. Improving the ability of the weatherization work force to employ diagnostic reasoning and principles from building science will result in even more costeffective weatherization.

- Encourage agencies to direct their resources towards clients that have higher-than-average levels of energy burden. This can be done either through the selection of clients that have a higher-than-average energy burden or the determination of investment levels based on the preweatherization energy burden. Both the Single-Family and the Fuel-Oil Studies found that energy savings are greatest in dwellings that consume large amounts of energy prior to weatherization. These same households also tend to spend a high proportion of their income on energy. By matching levels of investment with potential for savings, overall program cost-effectiveness will improve.

- Encourage the efforts of states to mobilize other resources to address the rehabilitation needs of low-income housing. This will enable DOE resources to be focused more on energy-efficiency improvements. Most highperforming agencies have access to non-DOE funds to help pay for housing repairs. The Program will be stronger as more local agencies have access to non-DOE funds for housing rehabilitation while using DOE funds to improve energy efficiency.

- Establish technology transfer mechanisms to promote replication of the success of high-performing agencies. One striking finding of the SingleFamily Study is the tremendous diversity among local agencies. A challenge to DOE's Weatherization Program is to help bring the less innovative and less advanced agencies up to the level of the high-performing agencies in their region. 


\section{PUTTING IT ALL TOGETHER}
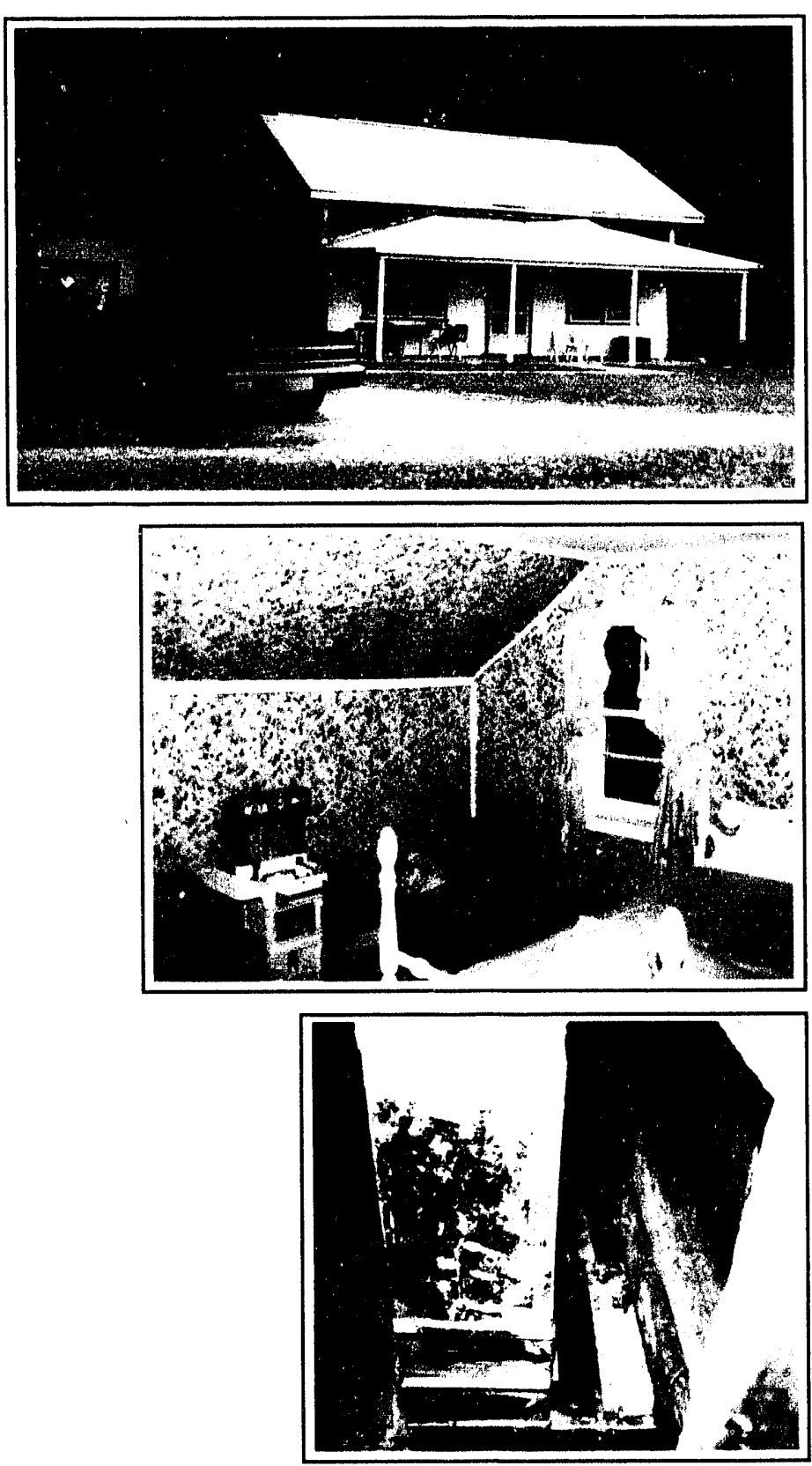

This home in rural New England had a weatherization job that reduced energy costs by more than 50 percent. After the knee wall on the second floor was accessed with a saw from the outside, extensive air sealing and insulation work were performed. (The access hole is now covered with a rectangular vent.) This weatherization job also included extensive repair of a leaky distribution system and other infiltration-stopping measures, including a new basement door. Although exterior aesthetics were not altered, the clients were overjoyed with a much more comfortable house--and a $\$ 600$ per year saving on their oil bill.

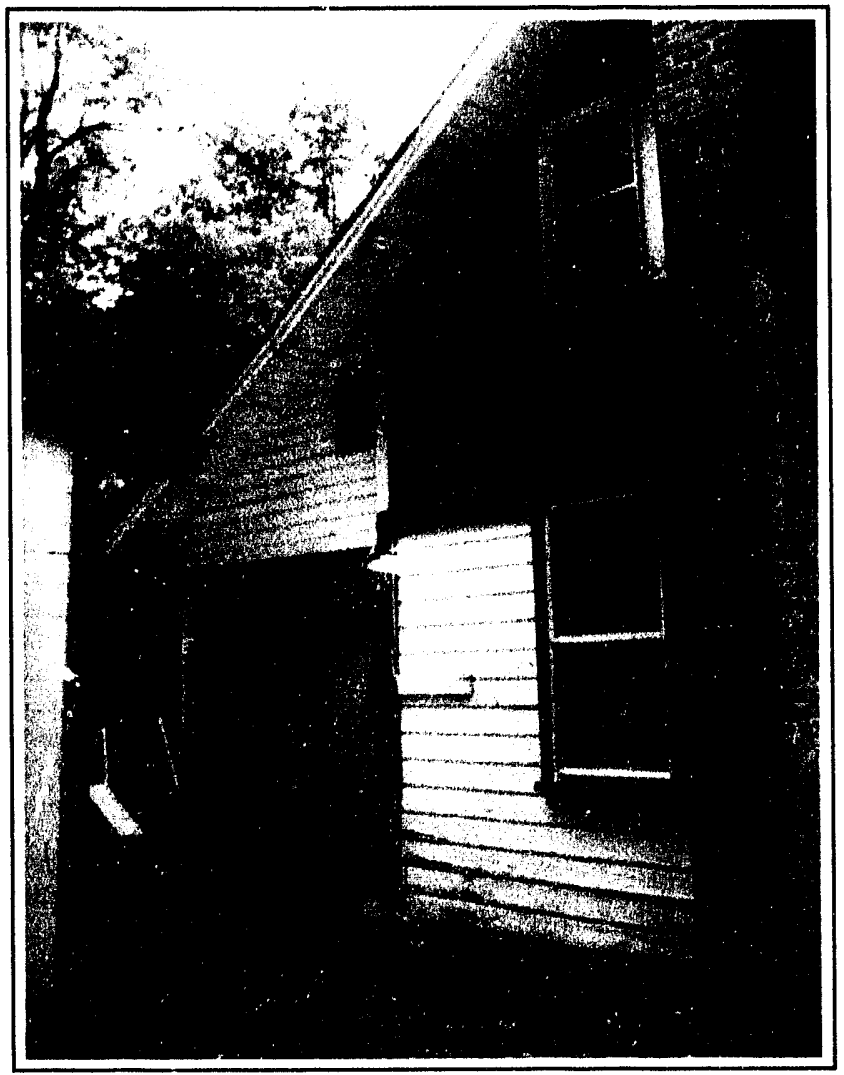




\section{B. Weatherization Measures}

- Continue the Program's strong emphasis on attic, wall, and floor insulation. High savings in both the Single-Family and Fuel-Oil Studies are associated with greater-than-average levels of investment in insulation. Highdensity wall insulation techniques that can achieve air sealing and insulation in the same operation appear to be especially effective.

- Further analyze the role of replacement windows and storm windows. The Single-Family and Fuel-Oil Studies have shown that large investments in windows are especially characteristic of dwellings and agencies that achieve lower-than-average energy savings. Yet at least one high-performing agency specializes in storm windows. Further, owner investments in the weatherization of large multifamily buildings tend to target storm windows. Additional research is needed to assess the conditions under which storm and replacement windows are a cost-effective Program expenditure.

- Increase the emphasis on replacing inefficient space-heating systems. High-performing agencies identified in the Single-Family Study replace more space-heating systems than other agencies. In addition, they make greater use of instrumented analyses of furnaces and boilers to select measures that promote health, safety, and energy efficiency. System replacements and instrumented analyses are characteristic of high-saving homes in both the Single-Family and Fuel-Oil Studies.

- Increase attention to heating system distribution systems. Dwellings that received duct leakage control measures and distribution system diagnostics achieved above-average savings in the Single-Family Study.

- Increase attention to water-heating measures. Water-heating conservation measures are characteristic of high-saving homes in the Single-Family and Fuel-Oil Studies. Measures to consider should include domestic hot water tank and pipe insulation, water temperature reduction, low-flow shower heads, and aerators.

- Select measures based on savings-to-investment ratios produced by audits. The Program should discourage the use of prescriptive methods such as statewide priority lists for the selection of measures. Audits that rank measures by savings-to-investment ratios, calculated for each individual house, produce more cost-effective weatlierization. Evidence supporting this recommendation was produced by analy.is of high-performing agencies in the Single-Family Study. 


\begin{tabular}{|l|c|}
\hline \multicolumn{2}{|c|}{ Significant findings of the National Weatherization Evaluation } \\
\hline \multicolumn{1}{|c|}{ Finding } & $\begin{array}{c}\text { Program-wide } \\
\text { value }\end{array}$ \\
\hline First-year energy savings per dwelling (in millions of Btus) & $\begin{array}{c}16.4 \text { (site) } \\
17.6 \text { (source) }\end{array}$ \\
\hline Energy savings as a percentage of energy used for space heating & $18.2 \%$ \\
\hline Energy savings as a percentage of total energy use & $13.5 \%$ \\
\hline First-year dollars saved per dwelling & $\$ 116$ \\
\hline Installation-related costs per dwelling & $\$ 1,050$ \\
\hline Program management and installation-related costs per dwelling & $\$ 500$ \\
\hline Total weatherization costs per dwelling & $\$ 1,550$ \\
\hline "Program" benefit/cost ratio* & 1.09 \\
\hline "Installation" benefit/cost** & 1.61 \\
\hline "Societal" benefit /cost ratio*** & $\$ 4.60$ \\
\hline Cost per million Btus of conserved natural gas & $\$ 0.04$ \\
\hline Cost per kWh of conserved electricity & \\
\hline$*$ Based on energy-savings benefits and total weatherization costs. \\
$* *$ Based on energy-savings benefits and total installation-related costs. \\
\hline weatherization costs.
\end{tabular}




\section{CONCLUSIONS}

Weatherization is a sound public program that has advanced technically in spite of modest funding over the past decade. It has concrete positive consequences for housing, neighborhoods, jobs, the environment, the payment of utility bills-and the economic well-being, health, and safety of the low-income people it serves. The Program is likely to becone even more cost-effective as agencies adopt more of the procedures and measures associated with higher energy savings and as new technologies emerge. The trend toward adopting tactics for effectively diagnosing where weatherization measures should be employed-and then installing the right measures for the circumstance-is very important and needs to be accelerated through thoughtful mechanisms of technology transfer.

The table on page 38 summarizes the findings of the evaluation of the Weatherization Assistance Program. 


\section{REFERENCES}

This summary is substantially based ont the following reports:

Brown, Marilyn A., Linda G. Berry, Richard A. Balzer, and Ellen Faby 1993. National Impacts of the Weatherization Assistance Program in SingleFamily and Small Multifamily Dwellings, ORNL/CON-326, Oak Ridge National Laboratory, Oak Ridge, Tenn.

Brown, Marilyn A., Linda G. Berry, Laurence F. Kinney, James O. Kolb, Thomas C. Wilson, and Dennis L. White 1993. Keys To Success: Ten Case Studies of Effective Weatherization Programs, ORNL/CON-328, Oak Ridge National Laboratory, Oak Ridge, Tenn., Draft

Eisenberg, Joel F., Eugene Michels, David Carroll, and Nancy Berdux, 1993. The Scope of the Weatherization Assistance Program: Profile of the Population in Need, ORNL/CON-330, Oak Ridge National Labo:atory, Oak Ridge, Tenn., Draft.

MacDonald, J. M. 1993. General Status of the Weatherization Assistance Program in Larger Multifamily Buildings, ORNL/CON-329, Oak Ridge National Laboratory, Oak Ridge, Tenn., Draft.

Mihlmester, Phillip E., Wallace C. Koehler, Jr., Mark A. Beyer, Marrilyn A. Brown, and Darrell A. Beschen, Jr., 1992. Characterization of the Weatherization Assistance Program Network, ORNL/CON-324, Oak Ridge National Laboratory, Oak Ridge, Tenn.

Power, Meg, Joel F. Eisenberg, Eugene Michels, Marjorie J. Witherspoon, and Marilyn A. Brown 1993. Scope of the Weatherization Assistance Program: The Weatherized Population and the Resource Base, ORNL/CON325, Oak Ridge National Laboratory, Oak Ridge, Tenn.

Ternes, Mark P., and William P. Levins 1993. Impacts of the Weatherization Assistance Program in Fuel-Oil Heated Houses, ORNL/CON-327, Oak Ridge National Laboratory, Oak Ridge, Tenn., Draft.

\section{NOTES}

' The typical dwelling that participated in DOE's Weatherization Program in 1989 is defined as a single-family detached dwelling, located in the moderate region, that heats primarily with natural gas. The Single-Family Study has energy savings estimates for 580 homes that meet this definition. These provide the basis for the profile of the typical dwelling.

${ }^{2}$ The typical agency is defined to be a local weatherization agency located in the moderate climate region that weatherized between 100 and 400 homes in 1989, most of which were gas-heated single-family detached homes.

${ }^{3} \mathrm{~A}$ barrel of oil is equal to 42 U.S. gallons and represented approximately two weeks of petroleum consumption per American in 1990. The "equivalent number of ba.rel(s) of oil" is, of course, a concrete way of expressing the 3,370 billion British thermal units (Btus) saved during 1990 due to weatherization work on single-family dwellings during Program Year 1989. In reality, of course, the savings occurred not only in gallons of oil, but also in hundreds of cubic feet (ccf) of natural gas, kilowatthours (kWh) of electricity, and other units of fuel. Where electricity is concerned, savings reported include the energy required to generate electricity at its source.

${ }^{4}$ Both of these constraints were altered by DOE rulemaking, the final version of which was published in the Federal Register of March 4, 1993. 


\section{ACKNOWLEDGMENTS}

For additional help in preparing this report, special thanks to Richard A. Balzer, Fred P. Baldwin, Ed Lapsa, Meg Power, Bill Wilburn, Marjorie Witherspoon, and all of the Working Group members who commented on the evaluation's numerous draft reports.

Weatherization Works has been produced with funding from the Weatherization Assistance Programs Division, U.S. Department of Energy. The guidance provided by the division's director, Jeanne Van Vlandren, is greatly appreciated. 


\section{APPENDIX A}

\section{EVALUATION DESIGN OF THE SINGLE-FAMILY STUDY}

The evaluation design for the Single-Family Study consisted of a treatment group of dwellings weatherized in PY 1989 and a control group of applicants for weatherization services.

\section{Sampling Design}

The sample was restricted to dwellings weatherized entirely, or in part, with DOE funds or with funds from other sources that were used according to DOE weatherization regulations. To make sure that the sample captured the diversity of the national program, the existing local weatherization agencies were grouped by size and region, and 400 of these a ancies were randomly selected. The 400 agencies then provided lists of the homes they weatherized in PY 1989 and lists of control homes awaiting weatherization. Using these lists, the researchers selected a sample of 18,748 weatherized dwellings $(13,162$ that heated primarily with gas or electricity, and 5,586 that heated primarily with other fuels) and 11,795 gasor electrically heated control homes.

The representative national sample was designed to be large enough to provide estimates of national program energy savings for PY 1989 and estimates of savings for key subgroups that were within 10 percent of the mean at a 90 percent confidence level.

\section{Data Collection}

Local agency directors were asked for specific data for each weatherized dwelling: characteristics of the house and its occupants, the weatherization measures installed, and the costs of labor and materials. Attrition at this stage was only 20 percent, mostly due to eliminating dwellings that had been weatherized outside of the study period.

Fuel-consumption records for one year before and one year after weatherization were requested from the 926 utilities that provided gas and/or electricity to those weatherized and control dwellings that heated primarily with gas or electricity. No effort was made to gather fuel consumption records for dwellings using other fuels such as fuel oil, kerosene, propane, wond, or coal. Despite extensive follow-up activities, attrition was significant: utilities provided complete data for only 4,796 (or 36 percent) of the 13,162 weatherized dwellings and 3,776 (or 32 percent) of the control dwellings that heated primarily with gas or electricity. Nevertheless, the data were sufficient to generate reliable savings and cost-effectivenes. estimates.

In a second phase of the Single-Family Study, a subsample of 500 weatherized dwellings and 300 control dwellings was identified for on-site field work. Inspections were conducted using a data collection protocol similar to the one developed for the Fuel-Oil Study. This phase of the evaluation is not yet completed.

\section{Data Analysis}

In determining savings due to conservation measures like weatherization, it is not enough to merely compare energy bills for a period before and after measures are installed. Weather and many othe, iactors affect consumption. For this evaluation, energy savings were calculated using the Princeton Scorekeeping Method (PRISM), a sophisticated and widely used procedure that normalizes energy use over time by adjusting for outside temperature differences. (PRISM is described in the Special Scorekeping Issue of Energy and Buildings, ed. M. Fels, Vol. 9, nos. 1 and 2, 1986.) The process is analogous to a procedure to normalize for highway and city driving in a miles-per-gallon analysis of automobile fuel consumption. 
After normalizing for weather, gross savings were calculated as the difference between energy use before and after weatherization. Finally, consumption of a large group of control homes was analyzed over the same periods. This enabled small (but accurate) adjustments to be made to account for changes in energy use that would have occurred in the absence of weatherization. Net savings of weatherized dwellings were computed by subtracting the average gross savings for control homes from the average gross savings for weatherized homes.

This analysis of savings was performed on all houses for which fuel consumption data were available, including those whose occupants changed during the course of the data collection period. Alaska and Hawaii were excluded from the National Weatherization Evaluation because the necessary field work would have been prohibitively expensive.

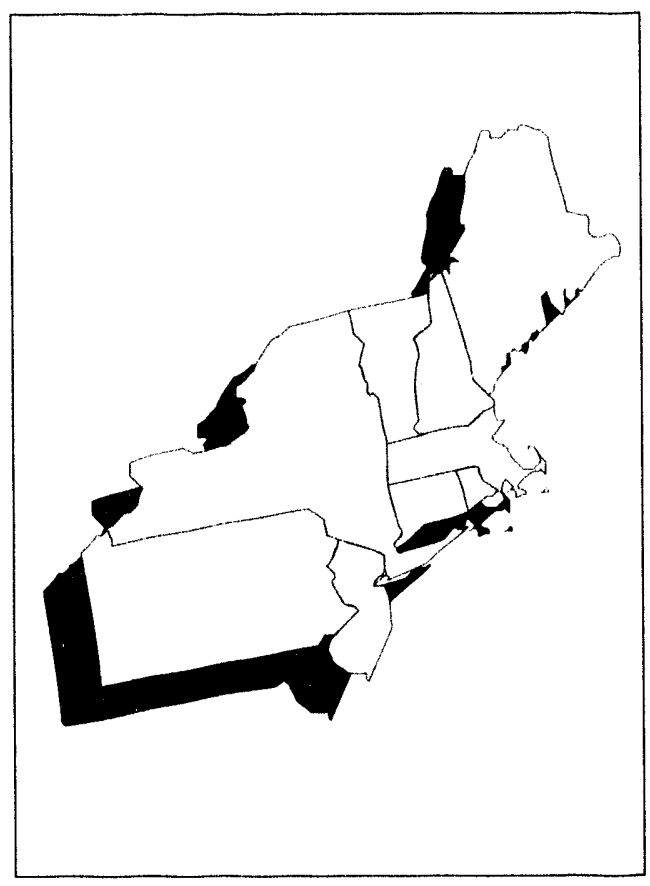

The Nine States Included in the Fuel-Oil Study.

\section{EVALUATION DESIGN OF THE FUEL-OIL STUDY}

This study was limited to single-family houses that heated primarily with fuel oil and are located in nine states in the Northeast. The evaluation design for the Fuel-Oil Study consisted of a splitwinter design involving two heating seasons (1990-91 and 199192). Weatherized homes received energy conservation measures in January of each heating season. The three months before and after weatherization comprised the pre- and post-weatherization data collection periods. This split-winter design reduced costs by allowing re-use of the instrumentation for a second year.

\section{Sampling Design}

At least two agencies were chosen from each of the nine northeastern states during 1990-91 and at least one agency from each state during 1991-92 to ensure a representative sample. Selection of agencies within states and test houses within agencies was random. In the 1990-91 heating season, 121 weatherized and 70 control homes, drawn from 25 agencies, were monitored. In the 1991-92 heating season, the remaining 101 weatherized and 45 control homes, drawn from a different set of 16 agencies, were monitored.

\section{Data Collection}

A data-logger in each house recorded inside and outside temperatures and heating system run-time data, and sent averaged hourly data each week via a modem to a central computer. Information about the physical characteristics of each house and its space-heating system was collected at the end of the postweatherization period. A comprehensive questionnaire was used to obtain occupant characteristics and their perceptions of Program impacts. Local weatherization agencies provided information for each house on service delivery procedures, weatherization dates, installed measures and costs, and household income.

Blower-door tests were performed before and after weatherization to determine changes caused by weatherization measures. Steady-state efficiencies of space-heating systems were measured in each house for both pre- and postweatherization periods. Safety inspections of space- and water-heating systems were performed at the end of the postweatherization period in all weatherized houses. Control houses were similarly tested. 


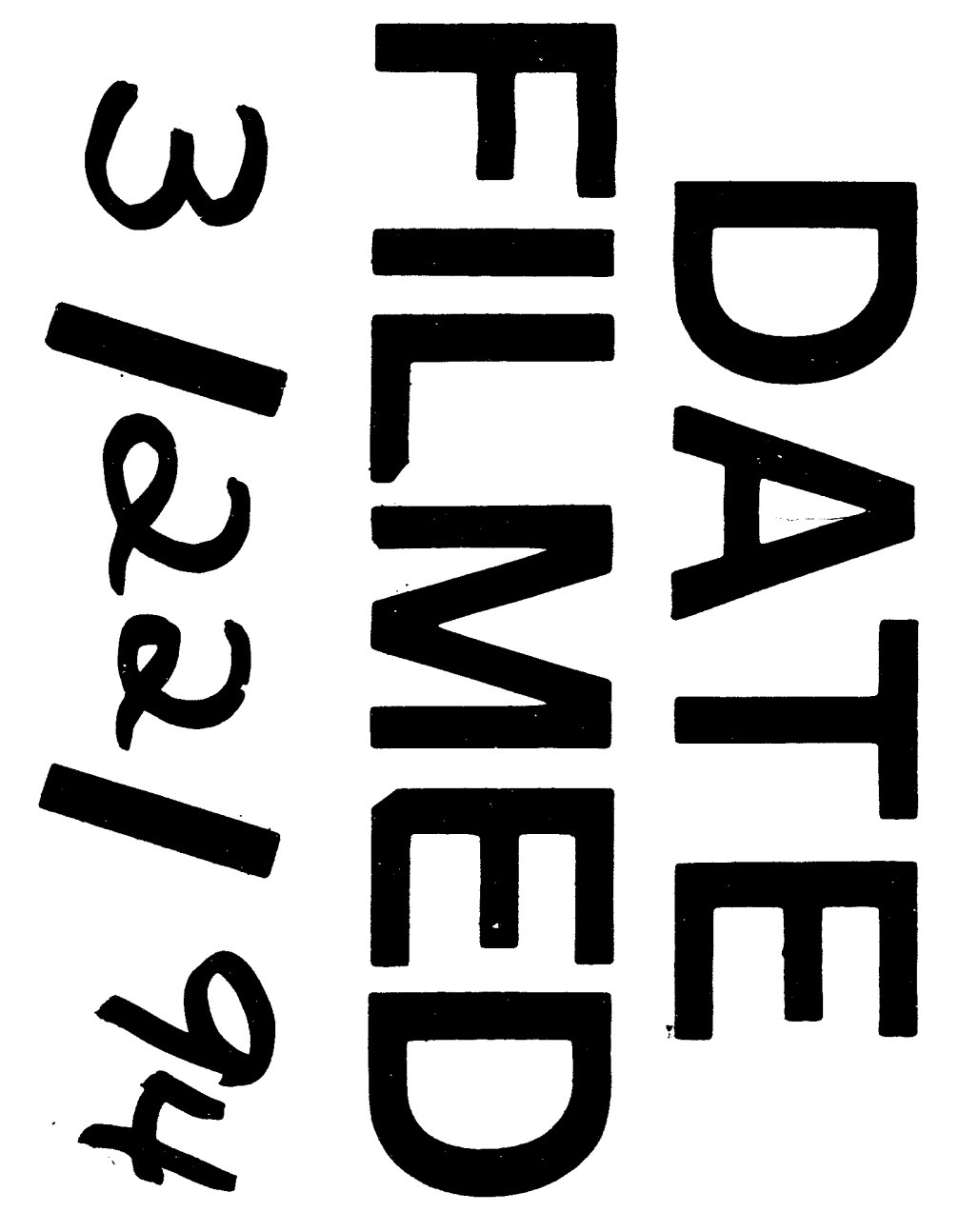

$\mathbf{x}$

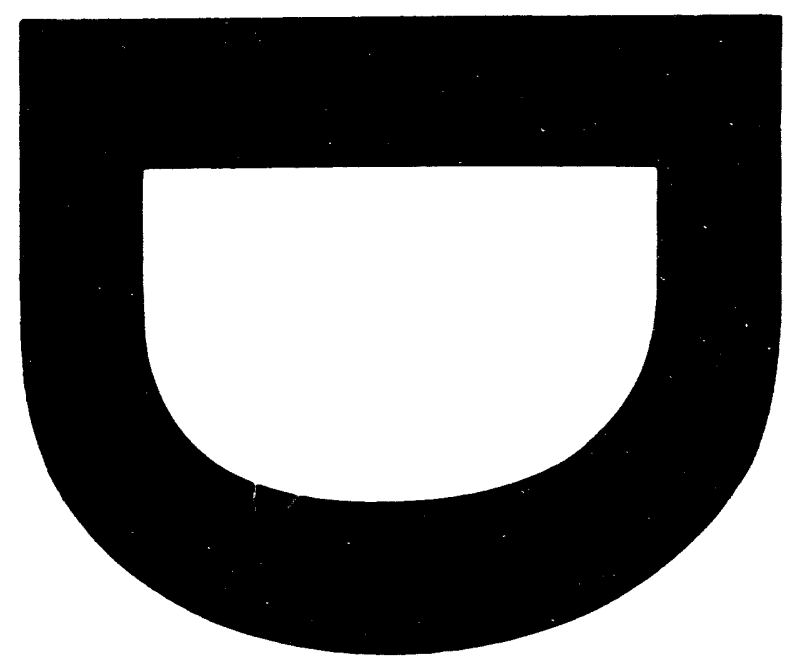

4 
